Portland State University

PDXScholar

1977

\title{
Important counsels to kings and imams by Shaykh 'Alwan ('Ali Ibn 'Attiyyah al-Hamawi) ; translation, with a historic introduction, the biography of the author and commentaries on the text
}

Abdullah S. Zaid

Portland State University

Follow this and additional works at: https://pdxscholar.library.pdx.edu/open_access_etds

Part of the Islamic World and Near East History Commons

Let us know how access to this document benefits you.

\section{Recommended Citation}

Zaid, Abdullah S., "Important counsels to kings and imams by Shaykh 'Alwan ('Ali Ibn 'Attiyyah alHamawi) ; translation, with a historic introduction, the biography of the author and commentaries on the text" (1977). Dissertations and Theses. Paper 2125.

https://doi.org/10.15760/etd.2123

This Thesis is brought to you for free and open access. It has been accepted for inclusion in Dissertations and Theses by an authorized administrator of PDXScholar. Please contact us if we can make this document more accessible: pdxscholar@pdx.edu. 
AN ABSTRACT OF THE THESIS OF Abdullah S. Zaid for the Master of Arts in History presented November 3, 1976.

Title: Important Counsels to Kings and Imams. Translation with a historic introduction, the biography of the author and commentaries on the text.

APPROVED BY MEMBERS OF THE THESIS COMMITTEE:

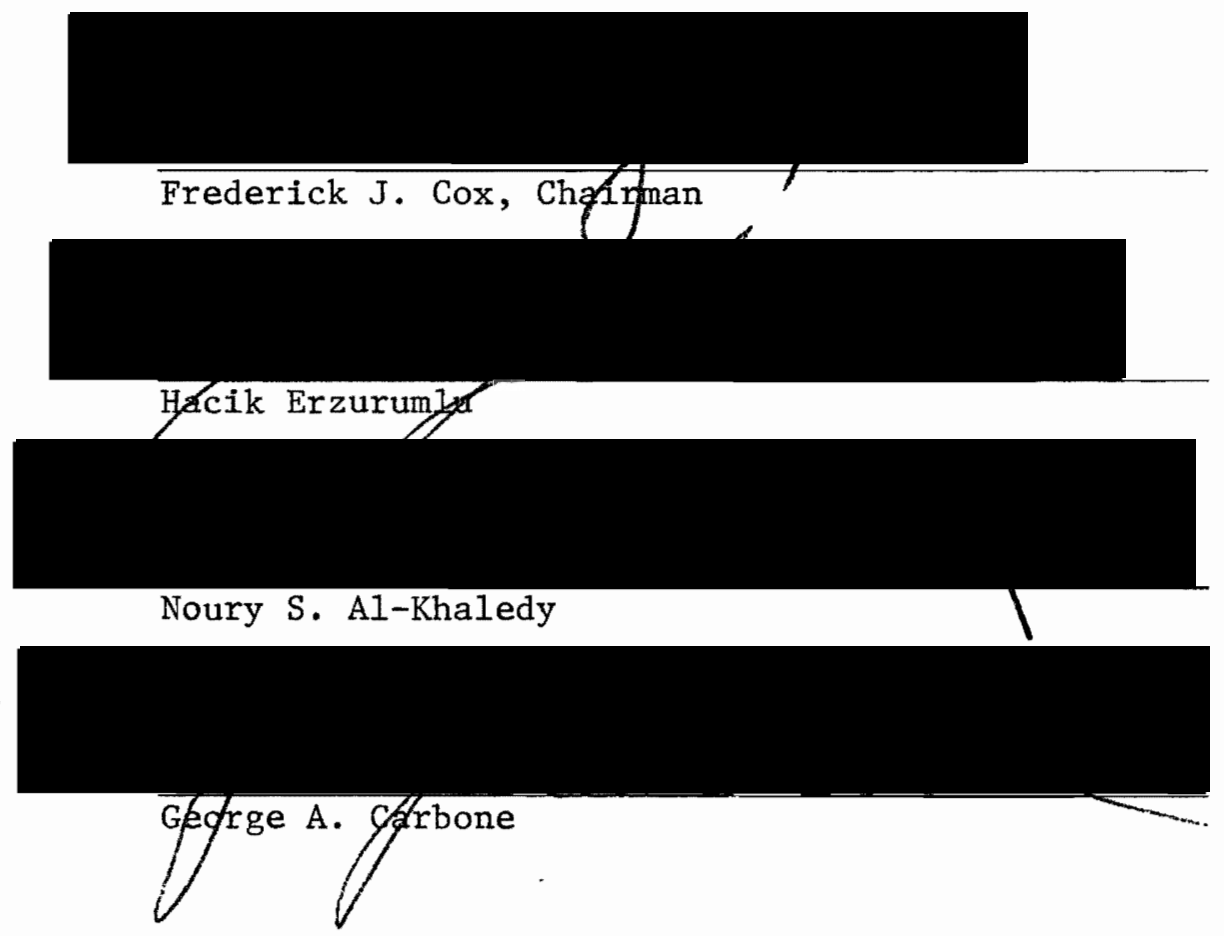

This thesis is intended to be an analysis of a book entitled "Important Counsels to Kings and Imams." It is, in the same time, a research on the book's author, named Alwan Ibn Atiyyah al-Hamawi.

Alwan was a Syrian muslim scholar, who lived in the sixteenth century. Alwan witnessed the Ottoman conquering of Syria, so, he wrote his book, Important Counsels to Kings and Imams, as a reflection 
of his views toward the Ottoman regime. Alwan addressed his book to Sultan Selim I, encouraging him to establish justice through the religious law, the Sharia.

The thesis is composed of four main sections; which are the following:

1. The Middle East in the time of Alwan. This section contains a short history of the Islamic states and the political relations among them. Those states were the Ottoman Turks in Anatolia, the Safawid Dynasty in Persia and the Mamluks' State in Egypt.

2. Life and career of Shaykh Alwan, his education and his Influence upon his society and students.

3. Analysis and commentaries on the manuscript, "Important Counsels to Kings and Imams. This section discusses the causes and goals of writing the book, the issues, which Alwan talked about, and finally the style of writing and organizing of the book.

4. Complete English translation of the Arabic copy Including all those chapters which are arranged by the author of the book, Shaykh Alwan.

The writer of this thesis has faced several problems with collecting information about Alwan's life, tracing prophetic hadiths and Quranic ayats, that Alwan included in his book, also translating an old manuscript written in a classic language.

Although, Alwan was one of the leading sixteenth century scholars and mystics, he has not been well-known to editors and publishers in this time in the Arab world. Only two books, out of twenty-four books and essays, are pubiished. 
All those references which I have used at Portland State University Library and al-Zahiriyya Library in Damascus, mention little information about the life and career of Alwan; especially his family and early life,

As for Quranic ayats and prophetic hadiths, which Alwan included in his book, all were mentioned without references or footnotes. Therefore, the writer footnoted every aya, but in the case of those hadiths, it was almost impossible to trace every hadith used in Alwan's book, and evaluate them according to texts, because of the writer's limited knowledge of the "Sclence of Hadith."

Alwan's book, which exists in manuscript form only, is grammatically correct in language, and the style of writing is generally good. However, the translation was difficult because some ideas are not clear and some classic Arabic words must be fully understood by using old Arabic dictionaries, then English dictionaries.

It seems that Alwan penned his thoughts haphazardly because the book seems. rather unorganized in its contents. Alwan divided his book into twenty-seven chapters. In fact some of those chapter titles are not necessary. He, sometimes, discussed some 1ssues more than once, such as alcohol and adultery.

Alwan in his book discussed numerous social problems and issues, 1.e., alms, commanding good, forbiding evils, adultery, alcohol, wearing pure gold for men, decorations of cities for the Sultan's joy, land taxes, and ensiaving free people, all attempting to set rules for the Sultan's judgment. 
At any rate the manuscript "Important Counsels to Kings and Imams" reflects the attitudes of a Syrian Arab scholar toward the rew Ottoman regime, that conquered Syria and Egypt between 1516-1517.

Alwan and his book are a significant commentary of Islamic history of Syria and Egypt in the beginning of the sixteenth century. Th1s research shows that Alwan felt that the regime of Sultan Selin I was not following its responsibilities toward the sharia and the only law of the Empire. The most important consideration for Alwan, in his manuscript, was his concern for justice for the subjects of the ottoman Empire. His goal in writing that book was that all people should benefit from the Quran and Sharfa, and that justice would be established through only the relfgious law (Sharia) within the Ottoman Empire. 


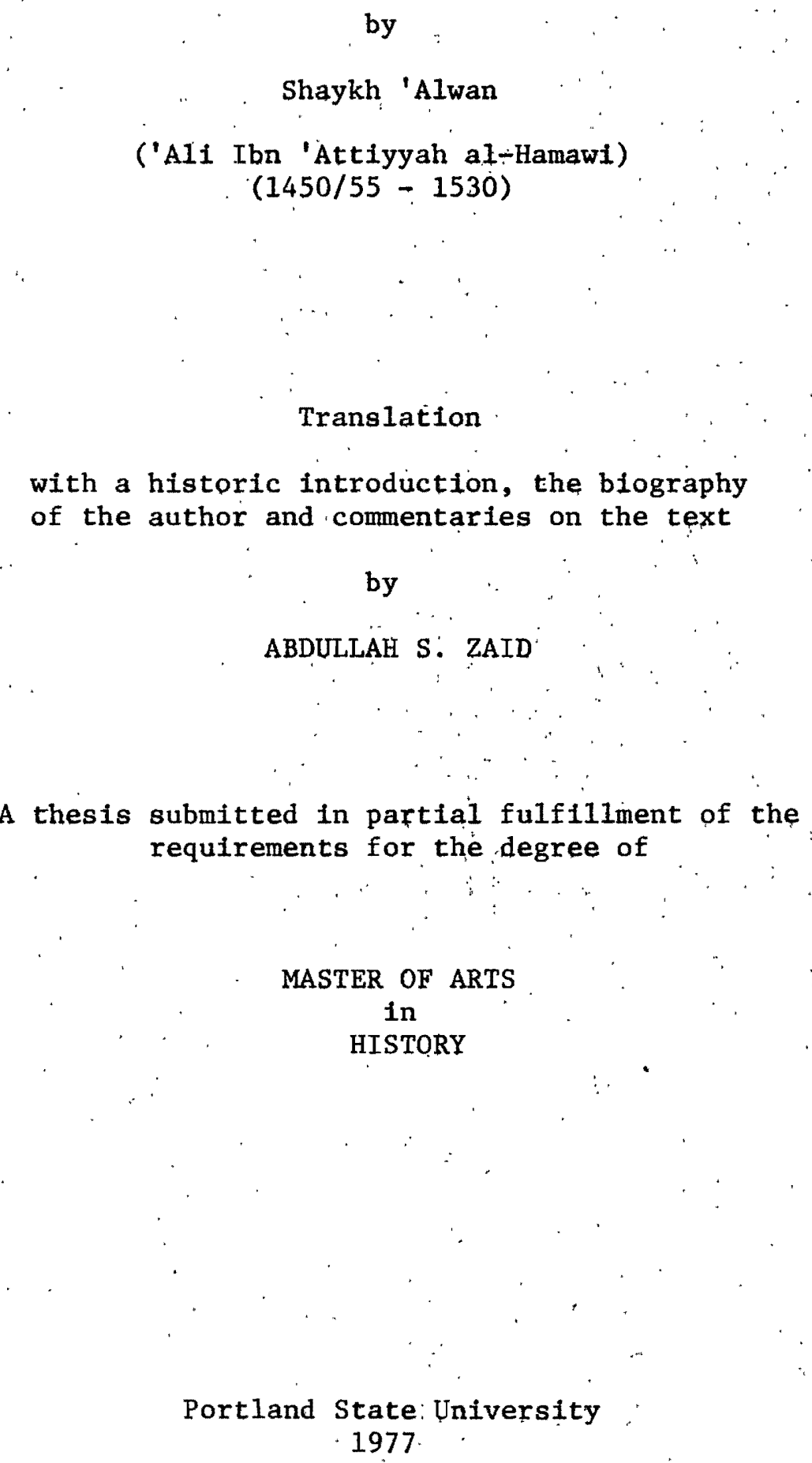


TO THE OFFICE OF GRADUATE STUDIES AND RESEARCH:

The members of the Comittee approve the thesis of Abduliah S. Zaid presented November 3, 1976.

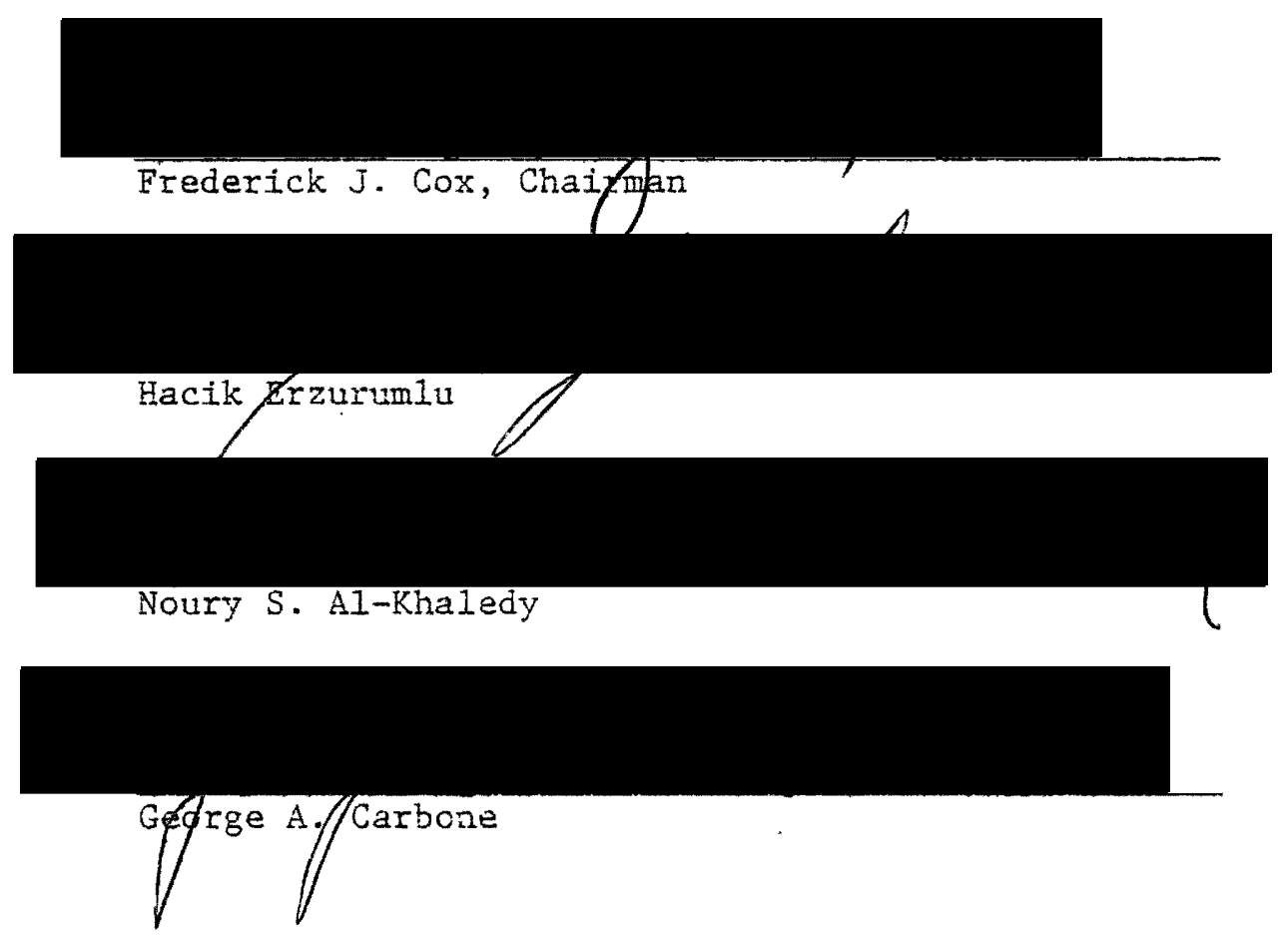

APPROVED :

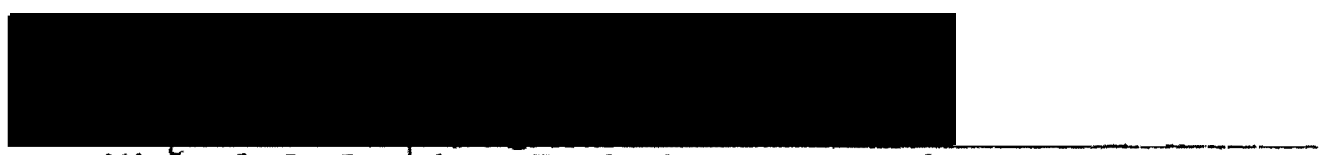

Michael F. Reardon, Head, Department of History

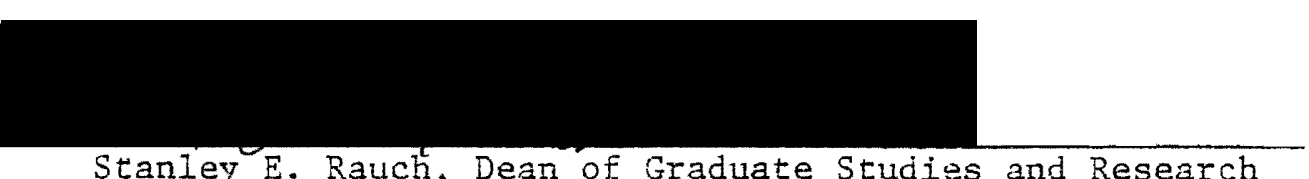




\section{PREFACE}

This paper is a study of Ottoman society in Egypt and Syria at the beginning of the sixteenth century, as portrayed by the life and works of Shaykh 'Alman, with particular reference to his book, Important Counsels. 'Alwan was one of the leading sixteenth century scholars and mystics.

Shaykh 'Alwan and his book, Important Counsels, provide a significant commentary of Islamic history of Syria and Egypt in 1517, by the Ottoman Turks.

Important Counsels, reflects the attitudes of a Syrian Arab towards the new Ottoman regime. In this historical and literary work, the writer has investigated the circumstances surrounding 'Alwan's decision to write Important Counsels and his views on morality and the enforcement of Islamic law under the new Ottoman regime.

Shaykh 'Alwan included many Qur'anic ãyats and prophetic hadiths, without mentioning references or footnotes. The writer footnoted every ayat using "The Quranic Encyclopedia" and "The Dictionary of Words of The Quran."

As For the Arabic version of the Qu'ran, "The Meaning of the Glorious Koran" the writer used for reference, is by Mohammed Marmaduke Pickthall. It was almost impossible to trace those hadiths used in this book, and evaluate them according to their texts, not only because of the scarcity of the hadith reference books, but also the writers and limited knowledge of the "Sciknce of Hadith." 


\section{iv}

I have attempted to foothote some hadiths, used by 'Alwan, by referral into Islamic scholars, namely those who traced and evaluated hadiths, such as al-Ajluni and Ibn al-Kinani.

The last section of this study will be a translation of the manuscript, "Important Counsels To Kings and Imams," Erom Arabic into English. In my translations of 'Alwan's work, I have followed the style and the organization of the author without changes. Changes except some words are added between brackets for necessary clarification. 
TABLE OF CONTENTS

PAGE

PREFACE . . . . . . . . . . . . . . . . . . . . . 111

NOTES ON ARABIC TERMS . . . . . . . . . . . . . . . . . vii

LIST OF ABBREVIATIONS . . . . . . . . . . . . . . . . viii

CHAPTER :-

I THE MIDDLE EAST IN THE TIME OF SHAYKH ALWAN . . . . . . 1

The Ottoman Turks.............. . . 1

The Safawid Dynasty in Persia (1502). . . . . . 2

The Mamluks in Egypt $(1250-1517)$. . . . . . . 3

The Ottoman Foreign Policy in the 16th Century . . 5

II LIFE AND CAREER OF SHAYKH ALWAN . . . . . . . . . . . 7

Alwan's Education ............... 8

Alwan and Sufism . . . . . . . . . . 10

The Influence of Alwan ............ 18

Alwan's Sufi Disciples

Alwan's Books

III THE MANUSCRIPT "IMPORTANT COUNSELS TO KINGS

AND IMAMS" . . . . . . . . . . . . . . 22

Causes and Goals of Writing the Book. . . . . 22

Issues discussed . . . . . . . . . . . . 23

Style and Organizing . . . . . . . . . . 24

IV COMPLETE ENGLISH TRANSLATION OF THE ARABIC COPY INCLUDING MANY CHAPTERS WHICH ARE ARRANGED

BY THE AUTHOR OF THE BOOK, SHAYKH ALWAN . • • • . 27 
BIBLIOGRAPHY . . • . . . . . . . . . . . . . . . . 122

FOOTNOTES . . . . . . . . . . . . . . . . . 124 
NU'L'ES ON ARABIC TERMS

1. Awl1ya: Muslim salnts, mostly Suti holy men.

2. Awgãf: (Sing. Waqf) Islamic religlous endowment,

3. Ayah: A verse of the Islam's Holy Book, the Quran.

4. Faqih: (PL. fuqaha) The religtous Interpreters of the Islamic religlous Litw, the Sharia.

5. Hadith: (Sunna) The tradition of Prophet Muhammad.

6. Holy Hadith: A special kind of Prophettc tradition, which 1s. spoken by Allah, but is not considered as Quran.

7. Jihad: The Holy War.

8. Karamat: Miracles by Awliya.

9. Mutc is \& Qadis: Muslim judges.

10. Surgh: A chapter of the Quran.

11. Ul.zina: (Sing. Alim) Religlous scholars, Including fuqaha, judges, theologists and Sufis. 


\section{LIST OF ABBREVIAT LUNS}

1. A. : Ãyah

2. H.: Hadith

3. Qu. : Quran

4. S. : Surah 
CHAPTER I

THE MIDDLE EAST IN THE TIME OF SHAYKH ALWAN

In Alwan's time (1450-1530) there were three large Islamic powers who dominated the Islamic world. There were the Ottoman Turks in. Asia Minor, the Mamluks in Egypt and Syria and finally the Safawid Dynasty in Persia.

The Ottomans and the Mamluks follow the Sunni sect while the Safawids follow the ShI' 1 sect in the Islamic religion, which created conflict between the Ottomans and the Safawids religiously as well as politically.

Before discussing the conflict and the relations among those three powers, which resulted in the defeat of the Mamluks and the Safawids by the Ottoman Turks, a review of the origins of each of those Islamic states might be helpful.

THE OTTOMAN TURKS

The Ottoman or Turko-Osmall Empire was founded in the late thirteenth century by Osman I. The Osmali-Turkos were the last of the Turkish peoples to invade the Near East.

The Ottoman state was ruled by Osman $I$, and his thirty-seven descendants until its dissolution in 1918.

The Ottoman state began as one of the many sma1l Turkish states in Asia Minor during the breakdown of the Empire of the Seljuk Turks. The Ottoman Turks began to absorb the other states and during the 
reign (1451-1481) of Mohanmed II they ended a11 Turkish dynasties. The early phase of the Ottoman expanston took place under Osman I, Orkhan, Murad, and Beyazid at the expense of the Byzantine Empire, whose capital, Constantinople was freed to' the 'Turks 'In 1453.1

During the 15-16th centurles, the Ottoman Emplre became the leading power in the East particularly during the rule of Sultan Selinl, who defeated the Safawids and conquered Syrta and Egypt endIng the Mamluks state In 1517.

. T. THE SAFAWID DYNASTY IN PERSIA 1502-1736

The Safawids were the descendants of the Suft Ishaq Safi-ad-Din, who traced his descent to an Alid who ostensibly immigrated from South Arabla. Safi-ad-Din, like his descendants down to the third generation, remained concerned with the saintly 1ife. He did not seek temporal power. He died about 1334 in Ardabil, In eastern Adharbayjan, province of Persia. 2

One of the grandsons of Shaykh Saf1-ad-DIn, Isma'11, became the founder of the Safawid dynasty. Isma'11 was born in July 17 , 1487.

In Astara, on the Casplan sea, Isma'fl gradually assembled a large band of followers. Hs victory over the Khan of Adharbayjan opened the way to Tabriz and there Isma'11 was crowned Shah of Persia in 1502 .

He conquered Iraq without much effort which made him the master of the holy places of the Shi'a, Najaf and Kerbela.

In spite of the fact that at least two thirds of the inhabitants of Tabriz were Sunnis, Isma'il immediately elevated the Shi'1sm 
to be the state sect.

After Isma' 11 had subjugated all of Persia, he came face to face with his opposing enemies, the Ottomans, assuming the mantle of the Shi'a defender against the Sunni Turks. ${ }^{3}$

THE MAMLUKS IN EGYPT, 1250-1517

The Mamluks [slaves] were brought to Egypt for military service by the Ayyubids dynasty in the eleventh century.

Then, as so frequently happened in Islam, a new race of rulers arose from among their masters. ${ }^{4}$

The word Mamluks means. "owned" and slavery was an avenue to political power in view of the basically military function of these so-called slaves in Islamic countries. Moreover, the relationship between a Mamluk and his master was one of kingship, not necessarily of slavery, so that the slave frequently succeeded his master in a position of authority and power.

The Mamluks' control of Egypt (1250-1517) is divided into two eras: (1) the Bahr1 State, 1250-1382; (2) the Burj1 State, 13821517.5

The Mamluks ruled Syria and Egypt for two and a half centuries. They did not try to merge with the indigenous people, for they were mostly slaves before becoming the aristocratic governing class. During their rule they fought continuously amongst themselves over the power in the state.

However, the Mamluks' influence on the Islamic world was very significant. They stopped the Mongols, who advanced into Syria and Egypt after they conquered Baghdad in 1258. They finished driving 
out the Crosaders from Syria and Palestine. They revived the Abbasid Caliphate in Cairo but in name only, after its destruction in Baghdad by the Mongols. They also encouraged the thoughtful life, particular1y the knowledge of Sharla, because they considered themselves as the protectors of Islam. They built schools, mosques and palaces and as a result, many scholars and writers emerged during Mamluk rule in Egypt. But, in spite of this large production of scholars, the Arabic language, prose and poetry remained poor, prose in particular. Prose and poetry were not encouraged by the non-Arab Mamluks, who did not understand Arabic literature.

Almast all writings in this period were religious, biographical history or encyclopedias. Philosophy was almost forbidden by the Sunni traditional Fuqaha, who believed that philosophy conflicted with Sharia.

The first ruler of the Bahri Mamluks was Abeg who was stationed on the 1sland of al-Rawdah. Consequently, he and his successors were called the Bahri (River) Mamluks, who were mostly Turks.

Among the famous Bahr1 Mamluks was Sultan Qalaum, who defended his domain in Syria against the Mongols. At his death in 1290 he bequeathed his empire to his son, whose descendants held the power in Egypt for four generations until 1382.

In 1382 a new family of Mamluk rulers took over the state and ended the system of hereditary succession, by simply electing the strongest or most energetic or cunning and sometimes, these new rulers were the Burji Mamluks, who were stationed in Citadel [towers], so they were called Burjis. They were mostly Mongols and Circassians by origin. 6 
IHE OTTOMAN FOREICN POLICY IN THE SIXTEENTH CENTURY

Otcoman foreign policy becane expansfonlst along two frontlers first, toward Europe which was the traditional policy of the Ottoman sultans for over two centurles, and second, toward the Near East. The new director of Ottoman expansion to the eastern Mediterranean began when Sel1m I, came Into power in 1512.

Selim I turned to conquer his eastern nelghbors for the followIng factors: (1) The emergence of the powerful Shl' 1 state in Persta (Safawid); (2) Military and the emergence of military factors, which enabled the European nations to slow the Ottoman advance into the Balkans; (3) The economic factors which motivated Selim I, to control the International waterways and to break the blockade which was put by the Portuguese in the Gulf of Suez. Selim I wanted to secure Ottoman trade by controlling South and East of the Mediterranean Sea; (4) Selim I had personality and ambitions. He wanted to add more provinces to his empire by making extensive conquests. He was a fighter and conqueror, while his father was a sufl and peace-loving. 7 Ironically, he was the first Ottoman Sultan to add domain to his empire at the expense of the Muslims, rather than the Christians.

As a result of the long conflict between the two Islamic sects Sh1'i Safawids in Persia and Sunnl, Ottomans, Sultan Selim I attacked the Safawid, Isma'11, defeating him in the battle of Ghaliran 1514. Then he advanced into the Safawid capital, Tabriz which became the eastern outpost of ottoman power. He then turned his attention to the other Islamic state, the Mamluks, who controlled Syria and the passes into Ottoman lands. 
The Mamluks had extended their power farther and farther northward, until they pressed against the Ottoman territories. They also suspected the Ottoman sultans were competing with them, in caring for the holy cities Mecca and Medina, for control of the holy places and the pilgrims was a privilege of the most powerful sultan in Islam.

In the lower province, the Turkoman dynasty of the Dhu-1-Qadir had been ruling that area since the middle of the fourteenth century. Ala-ad-Dawlah had been made ruler by the Ottoman sultan Muhammed II.

However, Ala-ad-Dawlah was removed by Sultan Selim I on his return from fighting the Safawids in the battle of Chaldrin in 1514. Sultan Selim I accused Ala-ad-Dawlah of amblguous acts during Selim's war with the Persian Shah, Isma'11.

The aging Mamluk sultan, Qansuh a1-Ghur1, tried to protect himself against any Ottoman intrusion into Syria through the Taurus province by allying himself with Shah Isma'il.' After crushing Alaad-Dawlah, Se1ım I in August 1516, ţurned south into Mamluk lands and crushed Qansuh a1-Ghuri at the battle of Marj Dabiq, north of Allepo. Sultan Qansuh a1-Ghur1 was killed during the battle. The whole of Syria now lay open for Selim I, and he entered Damascus on September 26, 1516. At first, Sultan Sellm I was willing to leave Egypt to the Mamluks if they acknowledged his sovereignty in the pulpit prayers and in their coinage emblem. But the new Mamluks' Sultan Tumanbey refused to do this, which made Sultan Selim I attack. him in his capital of Cairo. Tumanbey was defeated In January 1517 , after a bloody street fight, which he managed to escape, but soon afterwards was betrayed into the hands of Sultan Selim I, who hung him in Cairo on April 13, 1517. 
CHAPTER II

LIFE AND CAREER OF SHAYKH ALWAN

The discussion of Shaykh Alwan's early life is very difficult because none of the avaliable sources mention anything about his fam1ly; his childhood, or even hls birthdate:

However, these sources list his full name while describing him as A1-Hit1, wh1ch means "one who Is from Hit," then Al-Hamaw1; "one who is from Hama." "Al-HIt1" suggests that Shaykh Alwan's family originally came from Hit, a small anclent town located in West Central Iraq on the west bank of the Euphrates River, about 90 miles west of Baghdad. 9

Although Shaykh Alwan was born, ralsed and died in Hama, his birthdate is unknown, However, A1-Ghazzi, the author of A1-Kawakib A1-Sa'irah reported from Ibn Tulun, (a Syrian historian, 1475-1546, and a scholar in biography) who was a contemporary of Alwan, that Shaykh Alwan died in 1530 at nearly efighty years of age: ${ }^{10}$ That would contradict that Shaykh Alwan was born between 1450 and 1455 . It might be said that Shaykh Alwan's background was unknown because he was not famous until after he met his tutor, Alt fbn Maimun about 1500, who came to Syrla from Al-Maghrib for the purpose of spreading the teaching of the Shadhili order of Sufism. Before Alwan was educationally disciplined and taught Sufism by Ali ibn Maimun, he was an ordinary preacher in the Mosque of Hama.

On the other hand, even after he became well known, he did not 
try to obtain fame by discussing himself or his family.

\section{ALWAN'S EDUCATION}

Shaykh Alwan studied Sharia, particularly Hadith and Figh, with various teachers In Syria and Egypt. Among these teachers in Sharia there were three who had much influence on Alwan's thinking.

Al-Bazily was born in 1441, traveled to Azerbaijan seek1ng knowledge and education. He studied with different scholars in varlous fields in Sharia, Arabic language, logtc and theology. He came to Syria in 1466. In 1470 he went to Mecca for the pilgrimage, and after returning the same year, settled in Hama where he died in 1519.

Alwan studied Hadith with Al-Bazily, who was well known as a mufti, teacher and scholar: He lived an ascetic life, worshipping, teaching and fasting most of the time. 11

Umar Ibn a1-Shamma was born in Aleppo about 1475. He studied Hadith with more than 200 shaykhs in Aleppo, Damascus, Hama, Jerusalem, Cairo and Mecca. He was a scholar in Hadith (Muhaddith), and was wel1-known as "the Leading Muhaddith of Aleppo." He was Alwan's teacher in Hadith while Alwan was his shaykh in Sufism. They grew to be very close friends, corresponding and visiting each other. However, Ibn Al-Shamma acknowledged Alwan as his shaykh. ${ }^{12}$ Ibn AlShamma died in Aleppo in 1530, the same year in which Alwan died.

It is not known whether Alwan traveled out of Syria for the purpose of getting more education. However, his third teacher was an Egyptian Muhaddith (a Hadith Scholar) named Uthman A1-Deyami, who studied Hadith in A1-Azhar. He was born in 1418, and died in 1502. It is believed that he knew 20,000 Hadiths by heart, ${ }^{13}$ and he had a 
significant influence on Alwan's education.

In general most of Alwan's teachers in Sharia were Shafil, which was the same Islamic Sunni school of interpretation that Alwan followed. They were mostly Syrians from Damascus, Aleppo or Hama.

Although Alwan studied with several shaykhs, he was not wellknown until he was discovered by his educator All Ibn Maimun, who' came from Fez, Morocco for the purpose of teaching the Shadhili order In the East, particularly in Syria and Anatolia. Ali Ibn Maimun al-Maghribi al-Sufl al-Shadhili was born In Jabal Ghomarah near Fez in 1450. 14 He studied Sharia in Fez, where he became a teacher, then a judge. However, he left Fez to join his Idrisi cousin, All Ibn Rashid, 15 who was crusading against the Portuguese on the Northern coast of Morocco.

North Africa in the beginning of the fifteenth century was in a very difficult situation. Internally, Bani Wattas and Bani Marin were fighting over the power.' From the outside; the Spanish and Portuguese were attacking the coasts. Ceuta (Sabta) was occupied by the Portuguese in 1415.16

Ibn Malmun held a position in Ibn Rashid's army as a judge and religious advisor. For a time, All Ibn Rashid carried out all the counsels and directions of Ali Ibn Malmun; but after the Increase in the number of troops, to include the "rabble of the army," as Al1 Ibn Maimun called them, violated the religious rule which Ibn Maimun was greatly concerned about, he decided ta leave Ibn Rashid's service. $^{17}$ The religious roles that Ali. Ibn Maimun was concerned about, were commanding good and forbidding evil.

Ali Ibn Maimun started a new 11 fe by, looking for Sufist Shaykhs. 
In Tunis he met Mohammad Ibn Ahmad al-Tabbasi, who taught him Sufism. ${ }^{18}$ Afterwards, Ibn Maimun traveled to the East for the pilgrimage. He arrived in Damascus for the first time in 1488. In this trip he looked for the unknown Sufi, Ibn Habib, who showed Ibn Malmun the grave of Ibn Arabl in Damascus. After spending several months in Syria, All Ibn Maimun went to Brusa (present-day Bursa in Turkey), then to North Africa, later to return to Beirut in about 1495. During this second trip he traveled throughout Syria and entered Damascius in 1498. 19 It was during this trip that Alwan studied with him. After Ibn Maimun taught students such as Muhammad Ibn Iraq and Alwan, he returned to Brusa for the purpose of teaching the Shadh111 Order of Sufism. He spent flve years in Brusa, then decided to return to Syria. He arrived in Hama in 1505, staying there about two years, after which he left to teach in Damascus.

He strongly criticized unjust acts by the official authorities. He also accused the judges; particularly the Shafi' 1 Chief Justice Ibn Qadi Ajlun of misusing waqf's money in Damascus. As a Sufi, Ibn Malmun believed in Ibn Arabi, who died and was buried in Damascus, In 1240, whose grave was neglected until Sultan Selim I built a dome on it in Ramadan in 1517.20

Ali Ibn Maimun devoted his time to teaching his students, including Alwan who learned the principles of Sufism from him.

$$
\text { ALWAN AND SUFISM }
$$

Sufism, according to its followers is the striving of the soul for the purpose of purifying it. The object is to move the soul from one hal (spiritual state) to another until one reaches unity 
with God. It is based on the teachings of the Quran, Sunna and the exemplary lives of the Muslim Idealists. The Sufis belleve in the deep internal understanding of Sharia. They believe that Sharia is comprised of three moods, faith, acts and morality. 21

Sufls distinguish between two kinds of knowledge; first, knowledge that can be learned by using the mind and $\log 1 \mathrm{c}$, which they called "Ilm;" second, knowledge that can be learned only by disclosure, gnosis, which they called "Ma'arifa."?2

Sufism developed from the earliest period of Islamic life. The Prophet Muhammad and most of his disciples ifved in an ascetic way. With the expansion, of the Islamic State resulting in contact with other cultures, particularly in the 9 th century, the ascetic life crystalized and got its name "Sufism," Ifterally meaning wearing "Suf," wool.

By the beginning of the third Hfjrl Century ( 9 th century) Sufism was influenced by different cultures and began to establish its philosophy of love of God as well as the analysis of man's soul. As a result, the conflict emerged between Sufis and the Fuqaha, orthodox theologlans, who interpreted the Sharla according to 11 teral meaning. The Sufis accused the Fuqaha of being literal and unable to understand the deep meaning of Sharia. On the other hand, the Fuqaha accused Sufis of heresy because of their distorted interpretation of Sharia. This conflict continued until the second half of the fifth Hijri (11th century) when the very learned Imam, Al-Ghazal1, succeeded in making peace between the Fuqaha and the Sufis. Al-Ghazali took the Sufi's stde In explaining his Sufi faith according to the Sunna. Such a great effort made Sufism accepted by, and adjusted to the Fuqaha 
school. 23

In the 12 th and 13 th centuries, new concepts and ideas appeared In Sufism, such as al-Qutb, i.e., head of the hierarchy of awliya (saints) and the Perfect Man. The Suft theory of the Perfect Man states that the Universe is a huge man, and man is a small universe. All things in existence in the universe are deep-rooted in the human soul. Thus whoever knows himself, will know hIs God. He also will know fully all facts in existence whether they are visible or not: This is what appeared as the Mohammadian Reality, with the best example of the Perfect Man being the Prophet Mohammad. 24

Throughout the centuries of conflict between the Fuqaha and the Sufis, the latter tried to protect themselves from being excused of heresy by quoting from Sharia. Shaykh Alwan sald, "The Shaykh of our Shaykhs said; do not talk about The Way (Sufism) to people who do not belong to $1 t . " 25$

Also Alwan believed that the Sufi should respect Sharia by keeping its deep, internal meanings secret for the purpose of being kind to the masses who could not understand sufism. ${ }^{26}$

In 921, A1-Hailaj was executed by mutilation for his saying: "I am the truth." Also, Al-Suhrawardi was executed in 1182 A.D. according to the Fuqaha's fatwa. As a result, many Sufis turned to express their concepts in a special language, full of unclear hints and symbolism.

It was in this intellectual environment that Alwan was raised and educated. He began his career as an ordinary preacher in a mosque in Hama. Alwan tells the story of his męeting with Shaykh Al1 Ibn Maimun' sayịng: 
I used to preach in Hama, using notes like any preacher. One day Ali Ibn Maimun stopped by the place where I used to preach, telling me no! Alwan, preach from your head not from your notes -- but I Ignored him. All Ibn Maimun said that three times, then I realized that he was one of the awliya of Allah. Therefore, I said, My Shaykh, I cannot preach by heart unless you support me. Ali Ibn Maimun said, I will and you depend on Allah. The next day I came to preach çarrying notes in my sleeve in case. I needed them. When I took my seat I saw the Shaykh before me, then Allah granted success to me and I began preaching by heart. That Falth has been continued up to today. 27 .

After that meeting, Alwan became a student of Ali Ibn Maimun, who taught Alwan the Shadhilf Order of Sufism.

The Shadhili Order is related to Abu al-Hasan al-Shadh111, 1195-1258, who was born in Ghumara near Sabta (Ceuta) In Morocco. When he was young he traveled to many places in North. Africa, such as Qairawan in Tunis. He went to the East for pilgrimage many times. He also visitẹ Egypt, Palestine, Syria and Iraq. Al-Shadhili came to Egypt in 1244 after he visioned the Prophet in his dream telling him to move to Egypt for the purpose of teaching forty friends. 28 Among his Shaykhs were Ibn a1-'Arab1 and Abu al-Fath al-Wastt1, Al1 ibn a1-Hasan a1-Shaf1'1. (1256-1333).. A1 Wastiti was an ascetic Sufi. He wrote "al-Iksir;" a book about the famous Sufi Imam, alRifai'1. Al-Wasiti died at Badr, near Madina, on his way to Mecca for pilgrimage. ${ }^{29}$ Al-Shadhilf belleved in Sharia and Sunna. He said, "If your disclosure contradicts the Quran and Sunna, then cling to Sharia, saying to yourself that Allạh has guaranteed infallability in Sharia not in uncovering or in sight." 30

Al-Shadhili did not behave as a poor sufi. He had farms and horses. He did not wear the poor dress; however, he did not criticize the suft poor dreșs. He told his closest and most well-known 
of his students, Abu a1-'Abbas al-Mursi, "Know Allah then be whatever you want to be." Al-Shadhill did not write books, believing "my disciples are my books." 31 What written materials we have of his works are what his students transmitted of advice, prayers and awards (11tanies). The most famous of these prayers are the Sea Prayer and the Land Prayer. The Shadhili School prefers a thankful rich person, rather than a patient poor one. 32 .

Th1s was the Sunni Sufi School of which Alwan was taught by Shaykh Ali Ibn Maimun, presumably during Ibn Maimun's second coming to Syria in 1498. Shaykh Alwan was a rational sufi in his life. He did not live in a rough, abstemiousness, life traveling most of the time like most Sufis. However, he did go to Brusa in 1502 where Ibn Maimun was to visit him and teach sufi students the principles af Sufism under Ibn Maimun's direction. Alwan spent most of his lifetime in his home town, Hama, with his family. He did not follow Ali Ibn Maimun to Damascus or to Majdal Maush in Lebanon, where Ibn Malmun isolated himself for five months unt 11 he died in 1511. Although Ibn Maimun did not believe in Khalwa (being alone), Alwan believed that Khalwa is in the Quran, called a1-'uziah, meaning withdrawal; and in Sunna as I'itikaf, prayer in seclusion. Also the Prophet used to worship Allah alone in the Hira Cave in Mecca before the Revelation. 33

Ali Ibn Maimun ordered his students not to interfere between rulers and the masses, however, Alwan wrote the book "Important Counsels to Kings and Imams," as a reaction to some unjust acts in the ottoman regime. In his book, Alwan wrote as a preacher and faqih because it was written for non-Sufis. In Alwan's time the fuqaha were 
still the holders of power. They were the interpreters of Sharia for the public and they were the men of the law.

In Ibn Maimun's time there were two famous Syrian Sufis, who were' given preference by Ibn MaImun; Ibn Habib and Muhammad Ibn 'Iraq. Ibn Habib was suf1, but he was not known to the citizens in Safad in Syria. He used to teach children and perform calling to prayer. He became famous because of. Ibn Maimun, who looked for him everywhere in Syrla until he found him and made him known to all people. Ibn Maimun knew about Ibn Habib when Ibn Maimun was in North Africa. 34

Muhammad Ibn Iraq was different from Ibn Hab1b because he was a rich prince knight. However, he liked Suflsm and wished to change his life by foining Sufis, but he did not give up all his wealth, positions and properties until he met Ibn Maimun, wherever he went until the latter died. 35

In 1508 Ibn Habib came from Safad to Damascus to visit Ibn Arabi's grave; which was a holy shrine to Ibn Maimun and Ibn Habib. A historian sunni scholar, Ibn Tulun, belleved that Ibn Habib came to Damascus because of the absence of the official Qadis in Cairo. Ibn Tulun condemned Ibn HabIb because of Ibn Habib's believing in Ibn 'Arabi. 36 Ibn Tulun reported that in 1520 he saw. one of Ibn 'Iraq's students in the Umayyad Mosque wearing strange clathes, carrying a spear and a note in his hand.' He was reading from that note that fuqaha should not criticize Suf 1s, whose affairs are beyond the common mind. Afterwards the student was beaten in the mosque "and Allah averted their attack from the believers," according to Ibn Tulun. 37

Alwan believed in the Tajal1i (illumination) without Hulul (infusion of Allah). The Sufl interpretation of the Hadith, "Allah 
made Adam in His image," is different from fuqaha interpretation. The Suf 1 interpretation is that Allah appears in whichever shape He wills. The appearance of Allah is only to possess those shapes, just as Gabriel possessed Duhya al-Kalbi's body and other bedouins, when he came to the Prophet. 38 The Most High said,

Had we appointed an angel (our messenger), we assuredly had made him (as) a man (that he might speak to men); and (thus) obscured for them (the truth) they (now) obscure. 39

'Alwan distinguished between an arif, gnostist and an abid ascetic. The abid worships Allah and obeys His commands only for the sake of obedience.

It has been reported that an arif said, "If I had to choose between Paradise and praying two raka's (cycle of work and act surrounding prostration in ritual prayer) I would choose to pray, because prayer is a duty toward Allah, but Paradise is something that benefits myself. 40

Therefore, 'Alwan gave preference to the arif over abid, ascetic.

Shaykh Alwan also belleved in Karamat, "miracles." He sald

that Allah had chosen some people to be his awliya; then He exploited everything in the upper worlds and lower worlds to obey these chosen people. Those chosen people had been given the power over animals, carnivores, insects and birds; air, water and clouds. Thus they can control all these things by making miracles, Karamat.

"Whoever obeys Allah; everything: will obey him."41

It seems that Alwan, like his Shaykh, Ali Ibn Maimun, believed in Karamat, but they did not try to demonstrate them.

Ali Ibn Maimun drove out one of his bright students named Ali al-Kaizawant, from his company because of the "lion incident" in Hama. Ali al-Kaizawani was traveling with his teacher, Alf Ibn Maimun in the Hama area, where their trip was hindered by a lion. All Ibn 
Malmun told his students to remove the lion from their way peacefully by calling to prayer, but the lion did not move. Then al-Kaizawani stepped toward the Ilon, which vantshed before the students' eyes, but Ibn Maimun became angry with al-Kaizawant, telling him, "You have corrupted our way."

Even after the death of Ibn Maimun, Ibn Malmun's pup1ls, particularly Alwan and Ibn al-Shamma', would not accept the return of al-Kaizawani to their company until he brought a letter from Ibn Maimun's shaykh in North Africa, 'Arafa al-Qayrawani. al-Kaizawani came to Alwan in Hama and repented in 1521.42

However, the Alwan's son, Muhammad, reported In his book, Tuhfat al Halib, several exaggerated Karamat about his father, which he completed in 1536. He wrote that in his youth he had difficulties with understanding and memorization until he approached the coming of age. One night at dawn, he saw his father, Alwan, taken by a hal (transitory spiritual state of enlightenment), saying some sufi poems. After 'Alwan was released from the hal, he came out of the house and performed the ritual ablution (al-Wudu') in a wide brass vessel. When his father finished, Muhammad drank that water. From that time on, it became easy for him to understand and memorize. Muhammad said that he found his father's blessing ini the water. 43 .

'Alwan himself wrote a book about Karamat, miracles, entitled "Nasaim al-Ashar fi Karamat al-Awliya wa al-Khyar." This manuscript is found in the Zahiryya Library in Damascus, Syria.

'Alwan said about himself, in connection with Karamat:

It happens to me when I deal with ordinary people, that I tell them what in their minds before they tell me. This happened with one man three times in one day, which made 
that man say to ne wrongly that I an a telepathic person;

(Allah forbids that I should be among the foolish). 44

\section{THE INFLUENCE OF ALWAN}

The main ideological themes and styles of Shaykh Alwan can be seen in two major areas; in his teachings and in his pupils, including some of his Sufi colleagues, and the books he wrote.

To Alwan's colleagues he played the main role in the story of Al1 a1-Kaizawani, who was dismissed from Ibn Maimun's circle by -Ibn Maimun himself. In 1519 Alwan sent a letter to Ibn al-Shamma' in Aleppo warning people not to belleve or to follow al-Kaizawani, then residing in Aleppo. In his letter Alwan attacked a1-Kaizawani In a harsh language because of al-Kaizawant's violation of Ibn Maimun's teachings on the demonstration of Karamat in public.

Ibn al-Shamna' believed that the words 'Alwan used in his letter should not have been written about a religlous man 1ike al-Kaizawani. Therefore, Ibn al-Shamma' did not announce Alwan's letter to the public, although he hesitated to totally Ignore it, out of respect for its writer. Ibn a1-Shamma' read it to certain few people askIng for thelr opinton. However, finally, Ibn al-Shamma' made his declision not to publicize Alwan's critlcism of his decision of al-Kaizawani.

In 1521, al-Kaizawani came to Hama to apologize to Alwan for violating Ibn. Maimun's doctrine on Karamat. As a consequence, Alwan wrote Ibn al-Shamma' saying,

We have judged [al Kaizawani] according to what we can see, but Allah would take care of intentions. If you want to contact him [a1-Kaizawani], the matter is up to you and 
you know the hadith which says who repents of his sin is like who never had sin.

Ibn al-Shanma' was pleased with this result and he thanked Allah who had guided him to ignore Alwan's. critical letter in 1519.45

\section{Alwan's Sufi Disciples}

Among those people who learned from Shaykh Alwan were his two sons, Abu al-Fath Muhammad, the author of "Tuhfat al-Habib" and Abu al-Wafa Muhammad, who was not known as a scholar. Abu al-Wafa often accompanied his brother, the author, on his lecture tours. They both stopped in Damascus for fifteen days on their way back from a pilgrimage in 1532 where Abu a1-Fath preached and gave 1ectures In Sufism. 46 However, Abu al-Wafa apparentiy was not involved. in religious matters.

Abu al-Fath Muhammad was wearing the Khiraqah, the formal suf 1 dress, which was given to him by his father Alwan. He inherited his father's position as scholar, preacher and Shaykh of his father's order: He traveled to Damascus and Aleppo for the purpose of teaching, lecturing and meeting suf 1 scholars in these two cities.

There were three important Sufis, who were known as successors of Shaykh Alwan; Shakkas, Hamid al-Jinani and Umar al-Iskafi.

Hamid al-Jinani died in the second half of the sixteenth century.

Shakkas, who lived in Tadmur, used to visit Alwan's grave once a year in Hama. Shakkas died In the second half of the sixteenth century.

But the most Important of the successors was Shaykh Umar al-Iskafi, the shoe-maker, al-Iskafi quit his occupation, making 
shoes, and joined Shaykh Alwan's group. Despite al-Iskafi's illiteracy, he possessed knowledge of Sufism, which caused Alwan to send him to Damascus to teach the poor.

Umar al-Iskafi used to visit Alwan in Hama once every year and remained there for three days at a time, al-Iskafi lived an ascetic life teaching the poor and ance refused elghty gold dinars from the Turkish governor of Syria, Isa Pasha. Because of that refusal, the Pasha belleved in Umar al-Iskaf1. 'Isa Pasha, remarked once to Shaykh al-Iskafi that he released some thieves and drunkards because they told him that they were al-Iskafi's pupils. Umar'a1-Iskafi's' response was that, "If my pupils were disciplined and good; I would not have to teach them." 48

a1-Iskafi was an excellent disciple of Alwan and carried on Alwan's teachings in 16 th century Syria.

\section{Alwan's Books}

Shaykh Alwan wrote twenty-four books and essays concerning Sufism and related subjects. According to al-Alam (Second Edition 1954-59), only two of Alwan's books are published. They are "alJawhar al-Mahbuk," a Sufi poem about "traversing," and the other is "Bad1 al-Maani f1 Sharh Aqldat al-Shayban1," an interpretation of the Ideology of a1-Shaybani. Muhammad Ibn a1-Hasan a1-Shaybant, (748-804 $\mathrm{AD})$, was a well known Hanafi scholar, who wrote several books in Fiqh and the Science of the derivation of rules. ${ }^{49}$ His book, "The Belief of al-Shaybant," is a famous religious poem on theology, having been interpreted by four different scholars, including Alwan, in four different eras of Islamic history. 50 
Four of Alwan's books were interpretations of four well-known Suf1 poems, whose authors were al-Shaybani, Ibn al-Farid, Ibn Habib and al-Shushtari. He also wrote two full book's about al-Sirah, commenting on "The Biography of the Prophet" and "a1-Mira1," i.e., the Prophet's Journey to Heaven.

In Fiqh, Religious Law, Alwan wrote a book entitled "Misbah a1-Hidayah," 1.e., the light of guidance." The other fiqh essay is addressed to a common problem In Alwan's time, which was about looking and staring at strange women. 51 But the most important writing of Shaykh Alwan was his book, "Important Counsels to Kings and Imams." 


\section{THE MANUSCRIPT: "IMPORTANT COUNSELS TO KINGS AND IMAMS"}

"Important Counse1s" exists in manuscript form only. The copy used by writer is the Princeton UnIversity copy manuscript no. 3344, from Robert Garret collection of Arabic manuscripts: In the same time, the manuscript of a1-Zahiriyya, 1ibrary no. 3261 , also had been consulted.

The language of the manuscript is grammatically correct and the style of the writing is generally good.

Alwan mentioned that the reason for writing his book, was upon a request from a close friend: Alwan said:

I have been requested several times, by a close friend, to write this essay. He. [that friend] wanted people to benefit. from the Book [Qur'an] and the [Sunna].52

Alwan felt that the new Ottoman regime of Sultan Selim I, was not following its responslbilities toward the Sharia, as the Only law of the Empire. Alwan in his work urged the sultan several times to' send his decrees, all over his empire for the purpose of enforcing the Sharia, the religious law.

The most important consideration for Alwan, in this manuscript was his concern for justice, for the subjects of the Ottoman Empire and he began his writing with the following introduction:

Praise belongs to Allah, who establishes whom He wants to hold and wield the power... We do believe Mohammed is His servant and His Messenger... Whose Sunna is to support the oppressed, to strengthen the weak, to aid the helpless, and to mend the broken....53 
Alwan's book was addressed to unknown ottoman sultan, who is not mentioned by name. Moreover, from the historical events recounted by Alwan, such as destroying the former unjust Mamluks regime, by the Ottoman Turks, he wrote: "Allah made you the sultan of the honourable Mosques, in Mecca and Medina. Allah also has bestowed upon you the kingdom of al-Sham [Syrla]," but with no acknowledgment of hiss deeds. Sultan Selim I established his regime in Syrla and in Egypt between the period of 1517 and 1520, after which he returned to his. capitol city Constantinople in Turkey. Therefore, the indications are that the book was written during those three years.

Alwan was careful in his book not to arouse the sultan's anger. Throughout the book he emphasized the point that he was not arousing the people agalnst the new ottoman rule. His only purpose was to give counsel to the sultan in establishing the Law of Allah, Sharia. Alwan wrote: "...And among his [prophet's] orders, are the bringing of good news, the easing and calming, not causing adversity." 54 Alwan also emphasized the responsibilities of the sultan as the ruler, stressing that the Sultan would be questioned, on the day of judgement by Allah, about the condftions of his rule, as the following hadith says:

Whoever of you, sees wickedness, he is commanded to change it with his hand, if he cannot, then with his tongue, if he still cannot, then at least with his heart and that is the weakest of the faith.

Alwan believed that even though the above mentloned hadith was addressed to the Islamic nation in its entirety, it was more appreciable to Imams and sultans, because kings have the ruling hand; spears and swords; scholars only possess the tongue for preaching and 
condemnlng; The poor and the powerless, have only the heart for rejecting and changing evils. 55

Even though, when Alwan criticized the new otctoman Judicial system, he concluded...."... we are saying that for the purpose of informing, (the sultan) and Interceding [for the people]," 56 He justifled his criticism from the Quran.

Furthermore, Alwan stated that justice in the ottoman state must protect the powerful and the powerless people. Alwan wrote this diplomatic interpretation for the following hadith: "The best Jihad (crusade) is to tell the truth, to an unjust ruler." This hadith means that a fighter for Jihad is in a battle ground between the foy of winning and the fearfulness of losing. But the teller of the truth must risk his self-esteem, which makes it more dangerous, Alwan's commentary for this hadith, was that telling the truth to just ruler, such as the Sultan Selim, would be better than the best Jihad because in the case of the unjust ruler, the result would only be to eștablish the Law, Sharia of Allah. But with a just ruler the result would be more beneficial, because he would obey the truth, and he would be a good example to follow. 57

Alwan frequently in his manuscript urged the Ottoman sultan to care about the poor and the needy people, whose prayers for the Sultan would be strong support agalnst his enemies.

It seems that Alwan penned his thoughts haphazardly because the book seems rather unorganized in its contents. Alwan divided his book into twenty-seven chapters, [Fusul], and sometimes he discussed Issues in his writings more than once, such as alcohol and adultery.

The author strongly considered alcohol the mother of lewdness. 
However, he added that important people, who were unable to give up alcohol, could drink discretely but not in public. In another section of the book, Alwan returned to the same subject of alcohol, to relate that drinkers must be reprimanded whether they be princes, ministers; or most important people.

In general, the entire book is based upon the interpretation by. Alwan, of the three Qur'anic ayats:

(1) Those who, if we glve them power in the land, establish, worship and pay the poor-due, and enjoin kindness and forbid intquity. And Allah's 18 the sequel of events. [Sura, The P11grimage; Ayat 41.]

(2) Lo! Allah enjotneth justice and kindness, and giving to kinsfolk, and forbiddeth lewdness and abomination and wickedness. He exhorteth you in order that ye may take heed. [Sura, The Bee; Ayat 90.]

(3) The Most High sald, teling the story of Joseph, the truthful, "O my Lord! Thou hast given me (something) of soverelgnty and have taught me (something) of interpretation of events--Creator of the Heavens and the Earth! Thou art my Protection, friend in the world and in the hereafter; make me die submissive (unto thee); and join me to the righteous. [Sura, Joseph; Ayat 101.]

Alwan in the manuscript discussed numerous social problems and 1ssues i.e., Alms (Zakat), commanding good, forbidding evils, adultery, alcohol, wearing pure gold for men, decoration of cities for the sultans' joy, land taxes, and enslaving free people; all attempting to set rules for the Sultan's judgement.

Alwan also wrote about doing good to others [kindness], which included all types of social reforms, for the sake of, such as, poor and the needy, judges, schools, mosques, farmers, and preserving public morality, and ethics, as a guide for Ottoman rule over the Mamluk sụbjects.

It seems that Alwan did not like the Mamluks State, which he 
referred to it as a tyrant state. Although Alwan did not mention the Mamluks by name, it is clear that he referred to them when he wrote about taxes taken from the farmers. Alwan wrote:

But when Allah has abolished those States and stripped off the darkness of infustice, the honourable authoritartan body has come to follow that way of the tyrant gang. 58

However, Alwan preferred the Mamluks judicial system In spite of describing the Mamluks as a corrupt and tyrant state. The ottoman judiclal system placed high taxes on contracts and marriage 11censes, and Alwan begged Sultan Selim I to change the new judlcial law, or if not, to lessen the taxes.

Alwan concluded his book with hopes that the sultan would accept, understand, and carry out these sincere counsels according to the precepts of Sharia.

In summation, Alwan's goal in writing the book Important Counsels was that all people should benefit from the Qur'an and Sharia, and that justice would be established through the religious law-Sharias within the Ottoman Empire. Throughout his writings he attempted to be diplomatic in his attempt to move the sultan to act with justice and moral fortitude. 


\section{CHAPTER IV}

\section{THE KHUTBAH OF THE BOOK, 1.e., INTRODUCTION}

\section{IN THE NAME OF ALLAH, THE MERCIFUL, THE COMPASSIONATE}

Praise belongs to Allah Who establishes whom He wants to hold and wield the power; Who entrusts whomsoever He wants in HIs Kingdom; Who establishes him [the entrusted] with His slaves who are appointed to govern over people. Allah has protected and given a victory. to hIm [the entrusted]; and He obliges him [the Sultan] to thank Him for that grace, which, in turn, will be increased by giving us His graces and favors. We do ask Him for help to forsake His enemies. We do belleve there is no god but Allah - such a belief rescues us from the doom of the flame and provides the reward of Paradise. We do belleve Muhammad is His servant and His messenger, the carrier of good tidings, the warner and the light-giving lamp, who commands us to respect the adult and to have mercy upon the children, whose Sunna is to support the oppressed, to strengthen the weak, to ald the helpless and to mend the broken. And among his orders is the bringing of good news, the easing and the calming, not causing adversity, who is the best of horsemen and the bravest fighter when the battle becomes fiery. We ask that he be blessed and we salute him, his family and his followers. May the blessing last as long as Jihad continues and the trumpet is blown.

Now to our topic. This is an essay composed of honest advice 
and elegant preaching. I have been requested several times by a close friend, to write the essay. He wanted people to benefit from the Book of Allah and the Sunna. I rejected the proposal with kindness, but he insisted with good intention. Therefore, I became determined, with Allah's willing, to compose what is contained here, for whoever wishes to avail himself of it. By the dignity of our messenger, Muhammad, blessing and peace upon him, we seek Allah for beneficial results from this essay for the public and private.

Let us begin the discussion with the most High saying, "Those who, if we glve them power in the land, establish worship and pay the poor-due and enjoin kindness and forbid iniquity. And Allah is the sequel of events." [S. The P1lgrimage, A-41]. Allah the Most High also says, "Lo! Allah enfolneth justice and kindness, and giving to kinsfolk, and forbiddeth lewdness and abomination and wickedness. He exhorteth you in order that ye may take heed." [S. The Bee, A-90]. And the Most High sald, telling the story of Joseph, the truthful, "O my Lord! Thou hast given me (something) of sovereignty and hast taught me (something) of the interpretation of events - Creator of the heavens and the earth! Thou art my. Protecting Friend in the world and the Hereafter. Make me to die submissive (unto Thee), and join me to the righteous." [S. Joseph, A-101]. He, the Most High, tells about Solomon, the son of David, blessing and peace be upon them, who, he said when he saw the throne of Bllquis set in his presence, "This is of the bounty of my Lord, that He may try me whether I give thanks or am ungrateful, Whosoever giveth thanks he only giveth thanks for the (good of) his own soul: and whosoever is ungrateful (is ungrateful only to his own soul's hurt). For 1o! 
my Lord is Absolute in Independence, Bountiful." [S. The Ant, A-40].

There are many ãyahs on this subject [justice and thanking

Allah]. Also, among the prophet's speeches there are famous known Hadiths which talk in the same manner such as "The most loved person by Allah and the closest to Him is a just Imam and the farthest from Allah is an unfust ruler." Among those famous Hadiths, is his saying, peace and blessing upon him, the fust rulers will be on the pulpits, which are made of 1 ight on the right hand of Allah. Both of His hands are right, those who act justly in their rules and families and what they are entrusted with. He, blessing and peace upon him, also sald: "Dọ not curse a sultan who is the shade of Allah on the earth." 59 Through him (the sultan) justice arises, the religion appears [w111 be declared], infustice w111 be repelled, Impiousness wi11 be destroyed.

There are many quotations on that aspect, which we have left out for fear of writing in length. Therefore, let us, with the permission of Allah, discuss the first ãyah, "Those who, if we give them power in the earth..." which includes anyone given power, whether he is a king or a slave, a ruler, a minister, or a judge, influencial or not. But the imam and Sultan are more responsible for doing what that ãyah points out, which is the establishing of worship and paying the poor-due by word and deed, in his personal Iffe and public life because Allah did not bestow His graces on him and give him His sovereignty, just to eat and drink, to amuse or play, to rejoice or to be delighted; but He gave him [the sultan or imam] that grace for the purpose of helping His religion, forsaking His enemies, and to succeed His prophet and messenger to carry out the divine edicts and 
laws. He [the Sultan] must make people do their religious duties to Allah, which is pointed out by the Most High, "...Verily Allah helpeth one who helpeth Him. Lo: Allah is Strong, Almighty." [S. The Pılgrimage, A-40]: And again, "0 ye who belleve, be Allah's helpers..." [S. The Ranks, A-14]. Further, "O ye who believe! If you help Allah He w11l help you and will make your foothold flrm." [S. Muhammad, $A-7]$

Helping Allah here means helping His religion and His prophet, peace and blessing upon him, That helping w111 be done by following the Quran and the Sunna, by word and deed, Sharia and Tariqa and in reality, as much as possible according to His," the Most High, word, "Allah tasketh not a soul beyond 1ts scope...". [S. The Cow, A-286]. Again, "...Allah asketh naught of any soul save that which He hath given 1t..." [S. Divorce, A-7].

There is no way to achieve that purpose [following the Quran and Sunna] but by sitting with the scholars [ulama], reading the blography of the Prophet, peace and blessing upop htm, and the four wise caliphs and following their examples. By scholar, I mean those who know Allah and His messenger, who seek knowledge of religlous sclences for the sake of Allah, practice asceticism [abstinence from world11ness], and seek the Hereafter, who are sincere advisors unto themselves and others, who are striving for the way of Allah, and fear no blame from any blamer. These valuable scholars are very rare in these times. If Allah supports the King or the Sultan by giving him one of these scholars [mentioned above] it w111 be a great grace upon him when the King or the Sultan 1isten to them and obey what is for his own good. By following the Quran and Sunna, the rule was established and 
became stralght for the wise caliphs and those who came after $11 \mathrm{ke}$ 'Umar Ibn Abdul Aziz, may Allah be pleased with them all.

But the other kind of scholars who want, prefer, and are inclined to the world, they are worse for the nation than the Anti-Christ, the one-eyed 1lar, who comes just before the end of the world.

Therefore, the sultan and the like must avoid, remove, and take far away those worldly scholars. He must not help them with the1r. corrupt aims according to the Most High, sayIng, "Then withdrew (o Muhammad) from him who fleeth from Our remembrance and desireth but the iffe of the world." [S. The Star, A-29]. And in His speech "...so distinguish between us and the wrongdolng folk." [S."The Table Spread, A-25]. Allah, may be pralsed, compares the world1y scholars, in the Quran, whth donkeys and dogs, saying about Bal'am Ibn Ba'ura "...his likeness is as the likeness of a dog..." [S. The Heights, A-176]. Bal'am Ibn Ba'ura was a great scholar who knew the greatest name of Allah, however, he clung to the earth; i.e., he chose the worldly life and followed his own lust, I take refuge into Allah. Also, Allah tells about the scholars of the Jews who changed the Torah, "The likeness of those who are entrusted with the Law of Moses, yet apply it not, is as the likeness of the ass carrying books..." [S. The Congregation, A-5]. Llkewise, most of the scholars of the world, who changed what the Quran and the Sunna present, are also guilty, in their talk, behavior, conditions, habits, the way they eat and drink and dress, and in dealing with their families and their followers.

As a result, when their time:s kings saw the worldly scholars characterized by choosing the world, they, the kings, deceived them 
and hurt not benefited them. And it is Allah's help which is to be sought.

The Prayer

So that Allah may support and guide the man in charge, this ruler must send his honorable edicts and his noble letters all over the Kingdom to everyone legally obligated, to establish worship and pay the poor-due, whosoever private, publ1c, males, females, free, slave, a follower or a followed, must worsh1p Allah by the known way of the Sharia. The Sultan will order and warn the people according to their religious Imams' Interpretation of the Sharla. However, the Sultan is more deserving of the right to appoint a person or persons from the followers of Imams who belleve that the person who does not pray must be slain and never be left on the surface of the earth; because the sect of our Imam al-Shaf1:1 and his shaykh Imam Māllk and his student Imam Ahmad, says that those who do not pray must be killed regardless of whether they deny prayer as a task or not, but if they deny it they will be kłlled as apostates, or as Sharia punishment, if they do not pray because of laziness, according to the Most High, saying,"... But if they repent and establish worship and pay the poor-due, then leave their way free. Lo! Allah is Forgiving, Mereifu1." [S. Repentance, A-5]. So, what is understood by this ãyah is if they do not repent and establish worship and pay the poordue, then take them and besiege them, and prepare for them each an ambush. On the other hand, He says, "But if they repent and establish worship and pay the poor-due, then are they your brothers in religion..." [S. Repentance, A-11]. 
What is understood by the preceding ãyah is if they do not, then they are your enemies in religion. The distance between man and being a dis-believer and idolator is leaving prayer. The master of Arabs and non-Arabs, peace and blessing upon hIm, said: "I have been commanded to fight people until they say 'There 18 no God but Allah and Muhammad is H1s messenger' and establish worsh1p." How many people In these times, who don't pray, among private, public, male and female, free and slave, and how they are neglected! by kings princes, ministers and great men, who do not receive punishment, humiliation, are driven away and prevent others from praying. How difficult will be the reckoning of those who are in charge! before Allah and before $\mathrm{H} 1 \mathrm{~s}$ messenger, peace and blessing upon him. Those who are in charge will be asked on the Judgement - Day whereof the span is fifty thousand years: How disproved their argument w111 be under Allah! especially after He had established them in His earth and after the upper class and common people of H1s slaves have bowed to them. Therefore, wise people should beware of the Judgement Day and settle an account with themselves:by looking attentively in the speech of the truthful, the believables, the master of formers and the latters, peace and blessing upon him who said, "Everyone of you is a ruler and every one of you shall be questioned about these under his rule."60 That means the Imam, the Sultan, who is called al-Khudawandgar, is a ruler, 1.e., on anyone under his rule and his kingdom. The Sultan is responsible for his people, such as everyone: a prince, a great man, man and wife, employer and employee or servant, is responsible for those under his rule. 
The questioning of those rulers will not occur peacefully, but it will occur when the questioned is full with awe of Allah, the Greatest, the Most High. How could he not be filled with fear in that Day. when nations fall on their knees, when some prophets hang onto the leg of the Throne. On that Day "...faces humble themselves before the Living, the Eternal. And he who beareth (a burden of) wrongdoing is indeed a fallure (on that Day)." [S. Ta Ha, A-111].

If the questioned had helped Allah in the world and carried out His edicts according to His orders, then he will be in the safety of Allah under the shade of His Throne. The master of mankind says; peace and blessing upon him, "Allah shades seven people the Day when there is no shade but His shade, among those seven is a just Imam," 61 ! 1 .e., not oppressor, sultan...

As the Sultan sends his edfcts all over his kingdom urging the public and the private to establish prayer, he, at the same time, should deal with poor-due as the prophet did. The prophet, peace and blessing upon him, used to send out his employees in order to collect charities [zakat] and to recelve full poor-due and the like. These charlties and zakats are taken from the rich and given to the poor. The king or the sultan should have self-confidence and trust his employees not to treat people unjustly, greed11y, or unfalrly, then he appoints someone from his people and a group from his army, who fear Allah, who are honest with themselves and with their rich and poor brothers, who would not do wrong by taking gifts, bribes, fodder for their riding animal or hospitality for themselves without the permisston of the property's owner. The collector of the alms must not harrass people, not take 
their precious things or violate Allah's limits by word or deed. The prophet said to Mu'ath Ibn Jabal "By Allah! I love, Muadh," however, . when he sent him as the one in charge of collecting alms, he enjoined upon him not to take people's precious things and to beware of cursing of the oppressed, because there 18 no vell between 1 and Allah. 62 The Sultan or the King has the right to appoint any one of h1s men, whom he thinks has the mentioned requirements for collecting of alms. Must be distributed among the deservings of that town which the Zakat is collected from, but if there 1s more than enough, the Sultan gives the rest of the Zakat to other towns according to the legal rules [known rules] In each sect, including camels, cows, sheep, crops, fruits, and minerals. The Sultan should warn or punish severely when he 1s sure, those who violate the Zakat rules.

If the Sultan dfd that sincerely for Allah's sake, he will get unlimited reward according to the prophet saying, peace and blessing upon him, "Whospever calls on people guldance, he w111 gain reward as much as his followers gain." In addition, the Sultan will recelve more reward from Allah ta the Sultan for establishing justice and kindness, meeting the needs of the people, helping the oppressed, defending the Muslim needy and for terrorizing disbellevers and hypocrites.

al-Zakat, Alms

After the Sultan has established these two great tasks Islamic Pillars, prayer and Zakat and after the Two Tesifications, let us move ahead to what the ayah says: "Those who, if we gIve them power..." contains that which is doing good to others like tribal plety, helping relatives on the maternal side, generosity, trust, self-guard, seeking 
the beneficlal knowledge, remembrance of Allah; building mosques, schools, fortresses, citdels and bridges; improving roads; calming the frightened people - how? by the sweet taste of justice; commanding people to pray on Friday, to do the group prayer every day, removing annoying obstacles from the streets, perpetuating the respect of the Ka'aba by visiting it and the performance of the PIlgrimage by those who are able to do $1 t$, commanding them to love, Iike and visit each other, and following the Sunna avolding the intrusion of Innovations which oppose Islam. The Sultan also, commands to the other branches of the faith, but he should begin with the most important branches first and progress to the next important, anticipating Allah, the Most High.

As the Sultan commands righteousness, he should also forbid wickedness with his hand, his tongue and his heart according to Muhammad saying, peace and blessing be upon hIm, "Whoever of you sees wickedness he is ordered to change it with his hand; if he cannot, then with his tongue, if he st111, cannot, then at least with his heart and that is the weakness of the faith. "63 The phrase "whoever of you sees" Implies whom is told of or knows about wickedness is responsible for changing it. This basic matter, i.e., the commanding of righteousness and the forbidding of wickedness, even though $1 t$ is addressed to the nation in its entirety, it is more so addressed to the man in charge, especially the Imam and Sultan because the Kings have the hand, the spear and the sword; the scholars have the tongue for preaching, reminding and condeming; the poor and the powerless have only the heart for rejecting and changing the wickedness.

The anclent nations were destroyed, cursed, and transformed into 
monkeys and swine because they did not change and condemn wickedress. Allah, the Most High, said "Those of the children of Israel who went astray were cursed by the tongue of David, and of Jesus, son of Mary. That was because they rebelled and used to transgress, They restrained not one another from the wickedness they did. Verily evil was that they used to do!" [S. The Table Spread, A-78-79].

The messenger of Allah, peace and blessing upon him, sald, "When the children of Israel fell in the obediances, their scholars admonIshed them, however, they continued in the transgressions, then the scholars sat with them in their gathering places, ate and drank with them, then, Allah sealed up their hearts and cursed them through the tongue of David, and Jesus; Son of Mary. That was because they rebelled and used to transgress. [The reporter of the Hadith continued to say]: "The Messenger of Allah was reclining, then he abruptly sat up and continued "By. He who has my soul in His hands, unless you bend them [the wicked] to the truth" [Such is your fate]. The honorable, our master, the truthful, Abu Bakr, the successor of the Messenger of Allah. and justly so, may Allah look upon him with pleasure and, In turn, upon us, said "o! people! You read the following ayah! o ye who believe! Ye have charge of your own souls. He who erreth cannot injure you if ye are rightly gulded, [S. The Table Spread, A-105];" however, I heard the Messenger of Allah, peace and blessing upon hIm, "Ver1ly, when people see the wrongdoer but do not prevent it, perhaps, Allah w111 punish them a11," which means that the wrongdoer 18 he who transgresses any of Allah's limits, whoever he is public or private, prince or pauper. The Most High sald "... whoso transgresseth Allah's 11mits, whoever he Is he verily wrongeth the soul." [S. Divorce; A-1]. Also; He said 
"for whoso transgresseth Allah's limits: such are wrongdoers."

[S. The Cow, A-229]. The limits of Allah mean the law of the precious Sharia which is devised by Allah for His creatures in His infinite knowledge and legislated as law for His slaves by His prophets and messengers" tongues, when He says, "He hath ordained for you that religion which He commended unto Noah, and that which We Inspire in thee (Muhammad), and that which We commended unto Abraham and Moses and Jesus saying: Establish the religion, and be not divided therein..." [S. Counse1, A-13]. What is meant by religion is Islam, which is the submission to Allah and the obeying of the Book, the Sunna by word and deed, the commanding and forbldding, in private and public, in the practice of the Sharia and the Tarlqa, In the reallty of the fact; because Allah the Most High, says "...We have neglected nothing in the Book (of Our decrees)..." [S. Cattle, A-38], and "...every small and great thing is recorded..." [S. The Moon, A-53]; also "All things we have kept in a clear register..." [S. Yas1n, A-12]. Also, He says, "We have set thee ( 0 ! Muhammad) on a clear road of (our) commandant; so follow it, and follow not the whims of those who know not." [S. Crouching, A-18].

So, Allah ordered our Prophet, peace and blessing upon him, to follow the path he was set upon, which 1 s the Sharia of Islam and He forsook Muhammad to follow the lowly 1gnorants. Thus, what is ordered of our Prophet is addressed to us also; and what we are ordered to do the Sultan and Imam are more and more accountable, Similarly, whosoever is in charge, for example, ministers, Influencial men, judges and princes, whosoever obeys the commands of Allah gains victory and whosoever does not fails and will be the target of Allah's anger and 
wrath. Allah says, "...Whosoever obeyth Allah and His messenger, he verily hath gained a signal victory." [S. The Clans, A-71]. Also, "...And whoso obeyeth Allahand His messenger, He will make him enter Gardens underneath which rivers flow..." [S. Victory, A-17]; further, "Whoso obeyeth Allah and the messenger, they are with those unto whom Allah hath shown favour, of the Prophets and the saints and the martyrs and the righteous. The best of company are they!" [S. Women; A-69]. Allah tells about the transgressors and violators of the prectous Sharla and His 11mits: "... and whoso disobeyeth Allah and His messenger and transgresseth His IImits; He will make hIm enter fire, where such w111 dwel1 for ever." [S. Women, A-14]. Also, "...(M1ne is) but conveyence (of the truth) from Allah, and His messenger, and whoso disobeyeth Allah and the Messenger, 10! his is fire of Hell, wherein such dwe11 for ever." [S. The Jinn, A-23]. Further, [Allah said] "...who conspire to evade orders beware lest grief or painful punishment befall them." [S. Light, A-63].

Some of our scholars say: "grief". means to die disbelieving and to be cut off from Islam. Thus, whosoever violates the Law of Allah which is included in the Quran and Sunna; cannot be saved from dying as a disbeliever [non-Muslim], thus he enters the fire of Hell forever. I take refuge in Allah.

\section{Murdering the Human Soul}

The acts which constitute Immorality are innunerable, however, for the sake of brevity, we will not mention them in detail. However, we will point out the most vile of the Infquities, [the mothers of them ]. 
Among these are the slaying of 11 fe, an act which is forbidden, therefore, it is the obligation of the man in charge, may Allah give him victory and support, to intercede and prevent any one, both private and public, from doing 1t, obeying as Allah says, "And slay not the Ife which Ailah hath forbidden save with right" [S. Children of Israel, A-33]. He, also, said: "whoso slayeth a bellever on set purpose, his reward is Hell for ever: Allah is wroth agalnst him and He hath cursed him and prepared him an awful doom." [S.: Women, A-93]. The wise would do well to contemplate that great threat from the Soyerelgn Lord, the Owner of Glory, may He be praised. Look! how He threatens with the fire of He11! That He11, which, if one of its dwellers were to be brought to earth and made to stand still in the east, facing west, and to breath westwardly, the people in the west would succumb from the heat of his breath; and if one of its garments were suspended between the heaven and the earth; the temperature of that garment would Ifquify the mountains, inflame the trees, and evaporate the sea.. Imagine the condition of one who wears that garment upon his flesh. As if that punishment is not enough, He intensified it with eternality, 1.e.; everlastingly imposed upon the wrongdoer, who is imprisoned, descending into its deepest recesses. It is known that man was created weak, that he is unable to endure a lengthy stay in the bath [Turkish bath], for even a portion of a day or night. For example, when one takes a bath, there are bricks and mud between him and the fire, yet he can only endure the heat for about an hour; when he touches with his soft, smooth, delicate body and face that great fire which has been heated up for three thousand years, what then? He will be in Hel1; chained with his hands tight about his neck and his feet are also chained 
together so that he cannot protect himself or prevent the burning of his face. Allah says, "... and the Fire covering their faces."

[S. Abraham, A-50].

It is known that this fire of this world is one fraction of a degree out of sixty or more degrees of Hell. If this fire of the world had not been washed [cooled] twice with the water af the sea, it will never be useful for anyone in the world. $64^{\circ}$ Thus, one who slays a IIfe unjustly, commits an offense against the palace of the Soverelgn Lord, pulling down that precious construction (human body) which Allah has built with His hands, breathed in him something of His spirit, perfected his creation, established his foundations; restored his very fingers and firmed his heart. Allah had appointed whom He wants from His Realm (an angel) to guard that (human) construction for forty and forty and forty days ${ }^{65}$ unt 11 He breathed in him the spirit. Then that human construction became a fetus, a baby, a youth, then a middle-aged and an old man, until that criminal came and demollshed that prectous construction without the permission of its owner. Have you thought if one commits that crime against one of this world's Kings! by permitting himself to destroy that king's palace and defile his inviolibility! What would happen to him is a great anger, destruction and a long imprisonment. Therefore, Allah, The Most High, sald,"...Allah is wroth against him and He hath cursed him and prepared for him an awful doom." [S. Women, A-93].

Also, it is a fact that the master of human kind, the prophet, considered slaying a life unjustly one of the greatest enormaties. It is recited that the vanishment of the world is less important to Allah than slaying a Muslim life unjustly, or something close in meaning to 
that. However, this Hadith, mentioned above, has been reported in a correct Isnād (documentary tradition) by al-Tirmidhi and al-Nisā' 1 , which is word by word, the following: "Surely, slaying a bellever is more important to Allah than vanishing the world.", 66 ."

Also, the master of former and latter folk, peace and blessing upon him, said: "Whosoever assists in the slaying of a Muslim, even with part of a word, he, (the assistant) will meet Allah with this written on his forehead 'despair' under the mercy of Allah." 67 . We take rèfuge from the causes of His anger!

Usamah Ibn Zaid, the very honorable, is a disciple son of the disciple, the candidate and the beloved son of the beloved of our master [the prophet]. However, the Prophet placed a great blame on Usamah for his killing that man after he [that man] said, "There is no god but Allah." Usamah, Allah may be pleased with him, cla1med that the man was killing and maiming Muslims and protecting himself from being kilied by declaring the submissive to Allah hypocritically. The Prophet asked Usamah, "Have you torn open his heart?. Do you know he is your equal after he sald it? Or something to that effect?" Usamah wished that he had not converted to Islam before that day. Further, the Prophet relterated saying: "How would 1 t be when the Testimony comes, [in the Hereafter], disputing you before Allah," The aforesald Hadith is In Sadih of Muslim. 68 The Master of creatures, peace and blessings upon him, sald: "When two Muslims meet each other.with their swords, both of them are in the fire..."69 Also, the Prophet said: "To abuse a Muslim in a transgression and to fight with him is unbelief." 70 The Prophet said, "Do not become unbelievers killing each other after I leave this world." And, in continuing, "It is forbidden to slay a 
a Muslim unless he conmits one of the following three crimes: First, renouncing Islam; Second: adultery; Third: slaying a soul unfustly."7l Therefore, it 18 the duty of the men who are in charge, espectally al-Khudawandgār, Allah may support them all, to entrust princes, leaders, influencial men and soldiers not to shed blood unjustly unless there are legal reasons such as changing the religion or rebeling agalinst the Imam of the Muslims, then he must be punlshed according to the precious Sharia. When the sultan knows about an excess from one of his army shedding blood unfustly, he, the sultan, should condemn it and clear himself from it before Allah. The messenger of Allah, when he knew about killing of some people by Khalid Ibn al-Walld, he sald: "O Allah! I clear myself from what Khalld has done." 72

Khalid slew those people because they did not know how to say "we submit to Islam," Instead they sald "We have changed our religion.". Although, the sultan is obligated to punlsh whosoever sheds blood unjustly, according to the law of the preclous Sharia, which is retaliation, paying the blood-money, or sin-offering. The sultan is responsible for all that matters according to the Prophet, peace and blessing upon him, saying: "Everyone of you is a ruler." So, he will be questioned about these who are under his rule.

The Imam, the sultan, should send out his honorable edicts to the army not to frighten Muslims or point to them with weapons. In the case of slaying necessarily a life according to the law of Sharla, the imam should have the executioner do the execution right, because the Prophet, peace and blessing upon him, said: "Allah commands kindness in everything, so when you slay, slay right, and when you k111 [an animal] ki1l them right." 73 
The sultan should order the executioner, who is called, in our country, 'the lamplighter,' masha'ili, to allow the Muslim who must be killed, according to the man in charge command to allow the accused to pray two bowings [rak'as]. The disciple Khubaib, Allah may be pleased with him, did the Sunna of execution prayer, who said, [just before the Qureyṣh slew hIm in Mecca]: "I do not care to be killed and on which slde of my body for the sake of Allah, as long as I am a Muslim. Allah may bless my severed members."

Mutilation is forbidden, however, crucifixion and the like is legal when it is needed, such as for highwaymen, according to its laws in the Books of Fiqh.

Adultery and Its Punishments

Among the forbidden atrocitles are adultexy and sodomy, which have been practiced openly in this time. Therefore, the man in charge must remove them and establish Allah's 11mits aver these who commtt. those forbidden acts. The sultan is obligated to punish an unmarried person by beating him with a hundred stripes and exiling him for a year." In the case of slaves, males or females, [adultery punishment] is fifty stripes and a half year of exile. That previous punishment must be done if the forbidden acts are proved by elther conceding those sins by the sinful or by [legal] evidence. In the case of married people, males or females, [when they commit adultery] they must be stoned.

Allah entrusts the rulers only to establish such as these limits: Intercession for abandoning these limits against efther nobles or lowlier people is unlawful. If adultery or fornication cannot be proved, 
but it is wide-spread that they [males and females] committed the forbidden act of being alone with each other during a period doing a lewdness, then they must be prevented from doing that.

Among the great misfortunes in Islamic countries is the allowing of adultery publicly. In some of the Muslim countrles, the ruler or the Treasury-Secretary assumes a certaln amount of money from prost1tution. The ruler [of that country] 1s satisfled with that forb1dden 111gotten money. In that country young men and dissolutes are asked of an evil act by prostitutes in the streets and alleys. There is an appointed man in charge of taking care of these women and collecting that money from them. That kind of money, mentioned above, is called by the precious Sharia, "The Prostitution Dowry," which is collected with the permission of the man in charge in that country. It has been reported correctly that the master of former and latter folk, peace and blessing upon $h t m$, forbids the diviner's fee and prostitution dowry: Aiso, there is a kind of forbidden money, which is collected from the wine shops. I mean the spot where wine is sold safely with the ruler's permission. That forbidden money goes to the fortunate treasury. I mean the public treasury or it is spent on the army. That act does not please Allah and H1s messenger; in contrast with that, it causes the wrath and the anger of Allah. That act, also, offends the messenger of Allah in his grave; because the works of his community are shown to him there.

So, we wish that Allah may guide our master, the Sultan, alKhudwandgar to remove this ugly innovation, which causes Allah's wrath and anger upon the people of that area. If the sultan does that he will get a reward in his book [of record]. He, also, should take 
the opportunity from what the Master of the Heaven and Earth, Muhammad, the chosen, has said:

Whosoever makes a good rule in Islam, he will gain its reward, and will be rewarded for doing that rule by those who follow it until the Day of the Raising of the Dead. And whosoever makes an evil rule in Islam, its sin and the sin of those who do it will be upon the maker until the Day of the Raising of the Dead. 74

Allah would fill the fortunate treasury with His graces from His bounty's treasuries because Allah's are the treasurles of the heavens and the earth. Allah provides for the victorlous army from a different way, because He said: "And how many animals are there that beareth not its own provision! Allah provideth for 1 t and for you." [S. The Spider, $A-60]$.

Whosoever leaves a thing for Allah's sake, He gives him in exchange better than that thing. The entering of forbidden, 111-gotten, even that in doubt, [in the public treasury] may cause a falling, defeating and unholding firm in a bottle. It has come to our knowledge that a crusader man pald for his horse's fodder with a counterfeit dirham, 1.e., faulty dirham. When the fighters lined up before the battle, that man drove his horse toward the enemies but the horse refused to advance, which was not his habit. The man tried and tried to drive the horse to fight but he failed, so when he could not do any harm to the enemy, he returned to his home overburdened and he slept distressed. The horse came to him in his sleep telling him "You liked to use my back to fight unbelievers after you had put in the price of my fodder a counterfeit dirham." The man woke up and repented since then by paying the seller of that fodder a good dirham. Then he rode his horse again driving him toward the enemies. The horse advanced where as he had refused before. Thus, because of his respect for Allah, 
Allah gave what he wished [to do his Jihād]. On the whole, Allah, the Most High, enriched the army of the Master of creatures, peace and blessings upon hIm, and the disciples' armies after that, by giving them lawful booty and other [rewards]. Allah may enrich the victorious army from His bounty, Allah is generous, and ample of means.

Among the wickedness is wine; which is called the Mother of Lewdness, 75 that our Great Lord, the Most High, said: "O ye who beilieve! Strong drink and games of chance and idols and divining arrows are only as Infamy of Satan's handiwork. Leave it aside in order that ye may succeed." [S. The Table Spread, A-90].

The Prophet, peace and blessing upon him, ordered people to pour out their wines. When the forbidding of alcohol had been revealed, the disciples poured out the alcohol they had until the wine flowed in the sțreets of Madinah: So, it is clear that drinking, buying, selling, or Importing alcohol is against the law of the precious Sharia. Therefore, it is the duty to whom Allah spread out wide His hand, to help the religion of Allah, the Most High, and to follow the messenger of Allah, peace and blessing upon him, by pouring out the wine according to the Sharia.

If the soldiers, dependents of the army, and Important princes, are uniable to wean their souls from alcohol, and they crave 1t, then It should be drunk discretely; not publicly. It says, in the tradition: "Whosoever is tried with one of their sins (disobediences) should hide himself in Allah's she1ter." 76

When the sultan, the King enforced Allah's commands and protects His limits from being violated, Allah would șupport him strength, reverence, power, and aloftness. Allah said to His prophet regarding 
the Dwellers of the Cave: "If thou hadst observed them closely thou hadst assuredly turned away from them in flight, and hadst been filled with awe of them." [S. The Cave, A-19]. L1kewise, Allah will control people for the sultan and make them love him. According to His saying: "Lo! those who believe and do good works, the Beneficient' w111 appoint for them love." [S. Mary, A-96], Very little respect would be given those who commit erimes, shameful deeds, and sins, because Allah comes between them and the hearts of His people. This is because He does not love them [the sinful people], when someone is hated by the Truthful One, no one can love that person after that. We take refuge unto Allah from His hate and aloofness.

Defrauding People Their Rights

Among these wickednesses is diminishing to the people their rights and taking their money 11 legally, which is a wrongdoing. Allah says in some of His sayings: " 0 !' my slaves, I have forbidden myself wrong doing, which I haye forbidden it among you, so do not treat one another unjustly." [Holy Hadith (Quds1)] Also the Most High says: [in the. Quran]:

1. "Woe unto the defrauders:

2. "Those who when they take the measure from mankind demand it full,

3. "But if they measure unto them or weigh for them, they cause them loss.

4. "Do such (men) not consider that they will be raised again

5. "Unto an awful Day,

6. "The day when (al1) mankind stand before the Lord of the Worlds?" [S. Defrauding, A-1 through 6]. 
If this great threat concerning the defrauder, who diminishes his customer some of his rights, and how much more of that threat to the usurper and the tax collector and the 1ike, who eats people's money openly as it had been in the tyrant-sultans' time. Those tyrant-sultans whom Allah granted them time, then when He took them, destroying them, He did not let them escape. Why it should be so, He says: "Deem not that Allah is unaware of what the wicked do." [S. Abraham, A-42], The messenger of Allah says: "A Muslim is forbidden to another Muslim; his blood, money and honor."77 The messenger also says: "A Muslim's money is forbidden unless he gives it willingly."78

It has not been reported by efther he [the messenger] or anyone of the wise caliphs, who came after him, that they made tax or tamgha [a.seal, a tax on imports, etc.]. This was not allowable. Also they did not allow themselves to take tamghas or tax. Our scholars, Allah may have mercy upon them, still disapprove of one who takes tax. Perhaps they would call him a disbeliever. Therefore, Allah may cause our master, a1-Khudawandgar, bosom to d1late, so that he [in order to] remove this harm and put away this grief from the moslems. The Sultan will get an advantage of the prayers of the poor and needy people. The reward for doing that will reach the Sultan's book [of record] and his ancestors and descendants! books as we11. Allah may have mercy upon all of them. Allah will give the Sultan in return a good fortune in this Iffe and in the Hereafter: Allah will increase, also, the Sultan's glory. o Allah make us and him [the Sultan] among those who vie one w1th another for a paradise as wide as are the heavens and the earth. 0 , the victorious King! and the lucky Sultan, glory has origlnated its flag above your caravan. Good fortune has spread its garment upon 
you. People have obeyed you. The countrles have been well-ordered by you. You have become possessed of power; then pardon with goodness. You have obtained power, then forglve. Abolish these misleading. Innovations. Make these satanic events die. Make the face of the Mohammadan Sunna smile. Accept this interceding from a slave, who hopes that Allah makes him a sincere adviser to himself and to you. Selze the opportunity of the prayers of the poor and needy people.

1. "When your turns of good fortune come, avall yourself to them, because every wind sometimes must calm down."

2. "Hasten to do goodness with them (your turns), because you never know when calmness occurs."

The Sultan's Men Take People's Riding Animals Unjustly

Among those wickednesses is taking Muslim's animals 1llegal1y

and by force by the Sultan's men. The man in charge, Allah may give him a lasting happiness, must change and abollsh that mentloned habit. The Sultan must forbid this to his men [al-Wullaq], who he sent throughout the Kingdom, forbids them from taking of the Muslim's animals illegally by force. He [the Sultan], also, must prevent those men from beating or Insulting Muslims in cities or in the desert. Such an action is his duty, Allah may support him, because doing this is obeying the following Hadfth: "A Muslim is a brother of a Musilm, he does him no injustice, nor does he leave him." 79 ?he prophet also sald:

Help your brother whether he is the doer of the wrong or wrong is done to $\mathrm{h} I \mathrm{~m}$. They (his companions) satd: We can help a man to whom wrong is done, but how could we help him when he is the doer of wrong? He sald take hold of his hands from doing wrong. 80

This means that a Muslim must not leave his brother to someone to do wrong to him: 
Our Master!. Allah may support you, look into this speech by the most honorable of the creatures, your Prophet Mohammad, peace and blessings upon him, whose interceding, you hope in the Hereafter. Do not Ignore him; if you do, perhaps he will blame you when you stand before him in the Hereafter. He will say to you: go away from me; - taking refuge into Allah; - you and I are not related; have you not told this about me. "And whatsoever the messenger giveth you, take it, And whatsoever he forbiddeth, abstain (from it)." [S. The Exile, A-7]. I have commanded you to help your brother whether he is the doer of wrong or wrong is done to him; but you nelther help your brother by stopping him from doing wrong, nor supporting what wrong is done, by giving him his right.

0 the victorious King: do not think that what you, the army and others do is hidden from Allah, His messenger, the angels and the saints (awlya); because the Most High said:

And say (unto them): Act! Allah will behold your actions, and (so) will His messenger and the bellevers, and ye w $\$ 11$ be brought back to the Knower of the Invisible and the visible, and He will tell you what ye used to do. [S. Repentance, A-105]. Know [ to the king] that we have told that one of Allah's slaves lost his consciousness in as much as his family thought him dead. People, therefore, received word to do the funeral prayer for him; but his washer was clever and delayed the dead man's washing, day after day until three days had passed. Then that person whom they thought to be dead sat up saying "Give me gruei to eat." He was asked about what he had seen in his unconsciousness. He told his story which is briefly, that unconsciousness showed the messenger of Allah surrounded by Abu Bakr on his right, Umar [ibn al-Khattab] on his left and Umar ibn Abd 
al-Aziz in front of him. The man was astonished at Umar ibn Abd alAz1z's being so close to the messenger, When he asked how Umar ibn Abd al-Aziz obtained that close position to the messenger, he was answered that they, i.e., the two Shaykhs, Abu Bakr and Umar, may Allah be pleased with them, ruled with justice In the time of justice, but Umar Ibn Abd al-Aziz ruled with justice in the time of injustice. So, you, our Master are more deserving of this honor and more deserving to hasten to this spoll [gain]. Therefore, make your subjects taste the coolness of your justlce because they have been burned, before you came, by the heat of the tyrants' injustice.

Allah has made you and your princes wealthy. So in each town should be horses and animals for the mail, with the purpose of serving the needs of the people and the needs of the sultan. If one of the Wullaq, I mean to say, a delegate's horge could not take him to the next town where there were mail horses, and he by chance met a caravan, he should kindly rent one of those caravan animals. Renting the animal must not be against its owner's will, who should be paid by the Public Treasury.

This is what is required by the religlous $1 \mathrm{aw}$, which is designated as the Religion of Islam. Otherwise there are among the Invented Innovations which, are out of the Law of the Honorable Sharla. The Most High said: "Whatsoever the messenger giveth you, take it. And whatsoever he forbiddeth, abstain (from 1t)." [S, Exile, A-7]. The messenger said: "whosoever creates in this matter [Islam] something that does not belong to it, that creation will be rejected." The same previous Hadith has been repeated in another form: "Whosoever does an act that is not based on our matter [Islam], that act wi11 be a 
rejection, 81 meaning rejected or unacceptable.

So whatever the Legislator rejects the man in charge, - may Allah support him - and everyone must reject and not accept 1t. But if the man in charge accepts and does not reject 1t, that would be opposing and disobeying Allah and His messenger, Allah said: .

And whoso opposeth the messenger after the guidance (of Allah) hath been manifested unto him, and followeth other than the believer's way, We appoint for him that unto which he himself hath turned, and expose him unto hell - a hapless journey's end. [S. Women, A-115].

\section{The Celebration of Victory}

Among these evils is the victory celebration, which has become a common practice. This celebration must be changed and removed.

When an announcer of good news comes; with good news about a victory, such as conquering a city, killing an enemy and gaining his wealth and so forth, the governor of that town, which received that news, orders the mayor, called al-Klekhia, to collect money. Then the mayor starts hị job increasing the wanted amount, making even poor and needy people pay. They the mayor's men, perhaps supported by the governor's men, drag Muslims to jall beating and insulting them. Therefore, if the wronged cannot invoke evil upon his wronger with a tongue, for fear of being beaten, he will do 1 t in his heart agalnst whomever beats him, insults him, or harms him, whether he be a sultan, a governor, or so forth. He will invoke evil upon that person with his heart where the Great Mighty Allah looks in, who said: "Lo! nothing in the earth or in the heavens is hidden from Allah." IS. The Family of 'Imrān, A-5]. He also said: "He knoweth the traitor of the eyes, and that which bosoms hide." [S. The Bellever, A-19]. 
It has been known to the elite and the masses that the Invoking of Allah by a wronged person, against someone is to be raised above the clouds, and the Mighty Allah says: "By my greatress and mightiness I w111 grant you even after a period of time." Therefore, the Master of the formers and the latters, peace and blessing upon him, says: "Fear the Invoking by a wronged one, because there is no vell between it and Allah." As a result of forcing people to pay, it will be ingratitude of the grace of victory. We take refuge into Allah. This is due to the fact that graces must be thanked for in return. Thanking to righteousness is not to disobey Allah; because of His graces, it was more appropriate that charity be given to the needy, poor and weak people In every town, which make them inerease their prayers for their Imam and Sultan. This would be a cause for increasing the Sultan's victory and his success. The master of Arabs and non-Arabs, the Prophet, sald: "You get victary and provisions only because of the weak people among you. " 82

Allah may increase to us and to you His bounty - look into how our Prophet made the weak and their high-mindedness the reason for victory and success! Then how th the matter in contrast with that, which is taking money for that celebration from the weak people who cannot afford it?, because some people cannot pay even one dirham, how ever they are obligated to pay more than that many times.

Perhaps that matter is not known by our master, al-Khudawndgar, whlch is what we think of him, may Allah glve him a lasting victory and. good fortune: 
The Celebration of Sultans' Joy

Among these evils is decorating cities by the former kings. This happens when a sultan or king 1s happy about something. Then streets and shops will be decorated. The reason for considering this as an evil, is that Allah did not command us to cover rocks or bask In glory with wearing gold and silk. Indeed He commands us not to be deluded by this present life and to lead an anplous one. He forbade His messenger not to turn his eyes to the flower of the life when He said:

And strain not thine eyes toward that which We cause some wedded palrs among them to enjoy, the flower of the 11fe of the world, that We may try them thereby. The provision of thy Lord is better and more lasting. . [S. Tä Hä, A-131]. So, what is addressed to our Prophet is addressed to us except what is for his privacy.

We have known that one of the disciples; Salman al-Faris1, rejected decoration. Salman married a woman from the Kinda tribe. On the wedding night the bride's family decorated the house and covered Its walls with clothes. When Salman saw that, he sald; "Does your house have a fever, or the Ka'aba has been transformed to Kinda?'" Then he gave an order to remove these clothes and he mentioned that the Prophet forbade covering rocks. Likewise in the quoting from him [the Prophet].

Meanwhile, the Prophet sald: "My disclples are like stars, anyone of them you follow you will be gulded. "83 "The purpose of covering the Ka'aba with Kiswa, Is glorifying the signs of the religion of Allah. Also this is because the Ka'aba is the Holy House of Allah, that whoever enters it will be safe.

The decorating shops and streets, would result in gathering there 
some of the Implous, drinking wine publicly for all the world to see, declaring the obedience of the Generous Lord. This is the same as ingratitude to the grace of Allah upon them in front of their sultan and king. So much, that one of the merchants In our city was beaten with sticks. He was told that he falled to put more silk and fabrics for the decorations, which means that he hates a1-Khudawandgar.

We certainly know that all people used to invoke evil upon that former state, because of Injustice the people used to be In, meanwhile, those peoples were praying to Allah that He will establish al-Khundwangär. May Allah give him victory and support. Allah gave the Prophet and the wise Caliphs great conquest and huge spoils, however, they did not order decorations of elther shops or streets. On the contrary, they hastened to perform the gratitude bowing, thanking Allah for His grace of success and victory. They did not do either, with shamefulness nor demonstrate drinking wine. Those whom every wise person, efther from the elites or the public, must follow their example. The master of the creation sald: "Whoever Ilves after Me, he will see a big change: Therefore, cling to My Sunna and the Sunna of the wise Caliphs after me."

It was more suitable that the subject be ordered to fast, pray and do good, not demonstrate sinful actlons, Innovations and drinking wine; but verily to $\mathrm{All}$ ah we belong and verily unto Him we return.

Wearing Gold and Silk

Among the wickednesses is wearing gold and $811 \mathrm{k}$, which have become a general çommon misfortune. Many of the men, who are influential princes and big men, wear gold and pure silk. The messenger of Allah 
has forbidden men to wear such as these. This was sald by him [the Prophet] to Umar ibn al-Khattab, may Allah be pleased with him, when he saw him in a sira suit, 1.e., a silk suit, "whosoever wears this would have no share by Allah in the Hereafter." The messenger of Allah, said to a man who had a golden ring on his hand: "Some of you put a piece of fire on his hand." When that man heard that statement, he took off that ring and left without 1t. The Prophet took two pleces, one of gold and the other of silk, saying: "These are forbidden to my community's males, but they are legal for its females.: According to that previous Hadith, it is clear that gold and silk are forbidden. Our scholars, may Allah have mercy upon them, sald that the Legislator allowed women to wear gold and silk in order to populate this lower world with mankind. His, wisdom required that propagating, has to be brought about through breeding, which occurs because of sexual desire. Therefore, He made gold and silk allowable for women in order to attract men. Then the purpose that is required by Allah's wisdom will be achieved. As a result of this, it is known that men with decency refuse to imitate women. Why should it be so? The messenger of Allah has cursed those men who want to be like women. 84

What we know in the religious school of our Imam, al-Shaf11, may Allah be pleased with him, that gold and silk are not permitted to men for dressing up, however, gold and silk may be allowable in case of need, Here is not the right place to discuss those cases of need. If someone said that wearing. gold means an ornament; for the army and pride for the Muslims, and, on the other hand, coercion for the enemy, the answer will be that modesty is more than that. Our Lord, the Most H1gh, the Truth, says: "O Children of Adam! We have revealed unto you. 
raiment to conceal your shame, and splendid vesture, but the raiment of restraint from evil, that is best. This is of the revelations of "Allah, that they may remember." [S. The Heights, A-26]. "So what the Truth said is goodness otherwise evil.

If it is sald that the issue is controversial and some scholars made that allowable; the answer is, It is wise to take a safe route, because it is not wise to take a dangerous one. Let us suppose that you Intend to travel somewhere, then were told by a group of people that it will not be safe to go there, and in the meantime were told by one or by a group less in number, than the first group that your route was safe, wouldn't you be suspiclous that you take the route which is agreed on by both groups that it is safe. That route is pious and Allah-fearing.

The messenger sa1d: Leave what makes you doubtful to that which does not: "I have advised you, because I know lust! But what I see is the opposite of my advice, So, choose for yourself what you like."

Enslaving Free People

Among these wickednesses is enslaving free people. The meaning of that is that some of those who are close to princes order people to carry for them meat, bread, or barley [from the market to their house]. They may call upon some of the lads of the city in order to serve them. These beardless boys refuse to go out with them, fearing for themselves of sodomy and immorality. They hit the lads with a stick, stone or something heavy without avoiding hitting them in a vulnerable spot and so forth, so much that a boy of our town has refused to accompany them fearing for his honor, one of the wrongful, implous, who hit that boy 
with something and murdered him. As far as. we know the retaliation for that boy from the murderer has not been done. The reason for that is the witnesses would not dare to testify, fearing of the governor according to what we have been told. We hope that our master al-Khundawangar, may Allah give him a valid glory; of his obeylng Allah, that he look kindly to hlo subjects' situation by issuing his honorable edicts, which will prevent such corruption. Allah will reward him for that. In addition, the sultan will recelve an advantage of the weaks' prayers among his subjects for him.

\section{Soldiers Harrassing People}

Among the evils is attacking the subjects' houses by the moving army. Those soldiers come upon people's herem [women]. They stay in people's homes by force, which is the same as opposing the Book and the Sunna.. Allah; Who is Great and Mighty said:

: 0 ye who belleve! Enter not houses other than your own without first announcing your presence and invoking peace upon the folk thereof. That is better for you, that ye may be heedful.

And if ye find no one therein, stili enter not unt11 permission hath been given. And if it be said unto you: Go away again, then go away, for 1t 1s purer for you, Allah knoweth what ye do. [S. Light, A-27, 28].

The messenger of Allah also sald: "Permission has been made because of the sight."

The Prophet moreover, has allowed throwing something of the pupil of the eye of whoever looks through door holes and so forth. 85 If the thrower gouged out his [whoever looked] eye then the thrower won't be charged of anything, according to the rules for this case, which have been established [in the Flqh books]. In addition to this, the soldiers take by force the fodder of the hosts' animals for thelr horses, such 
as straw and barley. Besides they demand hospitality.

We have been told that one of the attendants and soldiers stayed as a guest with some people who recelved and honored him. Also they spent their night guarding that guest. But in the morning he claimed that he had lost a silky belt accusing them of stealing $1 t$. His claim was not proved in a legal way. He demanded from them such and such of dinars. The hosts were scared of being beaten by the city's governor and his representatives, or to be charged more and more for that belt; which the person claimed had been stolen.' Moreover, they would be taken to fail. That has happened to other people in the past: Wisdom says: "The lucky one is he who learns a lesson from the others' bad expertence."

So, the subjects have been confused. If they honor the guest soldier It will be harmful, if they dispute him, that will be worse and worse. In addition to that, those soldiers harass their hosts by asking for chickens, eggs, taking their horses to water, and watching their animals and so forth. The man in charge, may Allah give him more and more happiness, is responstble for that according to his saying, peace and blessing upon him: "... and every one of you will be questioned about those under his rule." However, [the sultan] does not know anything about this matter.

\section{The Hawtah System}

Among these wickednesses, is taking money unjustly from villagers and farmers. That money is called, sometimes protection fees and sometimes called Hawtah [encircling] according to the law of the unjust [former] rulers, may Allah not bless them for Muslims, save among them 
those who repented, belleved in Allah, then dId good acts.

The origin of this protection money, is when their infustice increased and their tyranny became common, and when the sultan used to ask for much money from town governors, before and after appointing them governors. As a result of this situation, governors expanded thelr greed toward people, money including the bedouins and city people. Every village, whether its people were powerful or weak, belong to a certain persons of these governors. They [the governors] respect a powerful person because of his power. Therefore, they don't exaggerate infustice to the people of his town. They do this for the purpose of reputation and hypocrisy, not for the sake of Allah. However, they don't care about the weak, destroy his farmers and village people. As a result of that, the weak people fled to the powerful, making for them a certain amount of money paid every year in order to protect them, from the injustice of the city's governor and his representatives. So, when the people send [that money] to the governor in order to abstain from doing them wrong.

Now Allah has removed these states and stripped off those injustices and darknesses; however, the secretaries of the honorable authorIty, since they came, have been following the example of that tyrant band. This harms many of the needy and poor people in the country, which makes them [now] call for help against injustice that is as it was before. Allah 1s, who is asked for help, The secretaries have Ignored this betrayal of Allah and His messenger; they continue to forget the following sayings of the Most High: "O ye who believe! Betray not Allah and His messenger, nor knowingly betray your trusts." [S. Spoils of War, A-27]. 
They [the secretarles] want to reform the world of the King, who trusted them; but they have corrupted their lives and his hereafter, because every dirham taken 11 legally must be returned to its deserving and Its possessor, according to the following saylng, by who doesn't speak of his own desire [the Prophet]: "Sufely rights will be returned to their deserving, to the extent that it w1ll be retaliating from a horned sheep, for the hornless one."86 It has been repeated in the tradition, that whoever takes illegally one danfque, one-sixth of a dirham, on the day of judgement, seventy accepted prayers will be taken out of his good works in return for that danique. Would to God if only one of us prayed one accepted prayer during his life time. How would the Truth accept prayers from those who do not fear Allah, Who sald: "...Allah accepteth only from those who ward off (evil)."." [S. The Table Spread, A-27].

The duty of the secretary is not to betray the one who trusted him [the sultan], because the hereafter 1s better than the world, so as to Inform the sultan of people's complaints of wrongdoing. Meantime, the secretary should Inform the sultan of the conditions of the poor and needy people, in order to have both the sultan and hils secretary, look Into the people's affalrs. But there 1s no strength nor. power but by means of Allah, the High, the Most Great.

Ibn Maimun's Jihad in al-Maghrib

If we count wickednesses we need to write volumes, but counting some of them would substitute counting them all.

Now we should turn to the honorable ãyah: "Those who if We give them power..." analyzing it as the following: 
The relative pronoun, who [in the àyah] could be accusative in two possibilities. First: The relative pronoun, who, is accusative because it is a substitution of the previous ãyah: "Verily Allah helpeth one who helpeth Him." [S. P1lgrinage, A-40]. Then the meaning will be "Allah helpeth who if We give them power..." This has become thus from an addressing speech from third person to the second.

Second: As praising [comes later on page 66]. The first possibility would indicate that the Knower, the Mighty, has guaranteed victory; support, strength and good fortune for those who support His religion, who preserve His IImits, who obey His order, who establish worshtp, pay the poor-due, enjoin kindness and forbid inquiry.

The following Quranic ãyah proves that guarantee:

0 ye who belleve! If you keep your duty to Allah, He w11l give you discrimination (victory)... [S. Spolls of War, A-29].87

And that Our Host, they verily would be the victors. [S. Those Who Set The Ranks, A-173].

And whoso taketh Allah and His messenger and those who belleve for friend (w111 know that), 10! the party of Allah, they are the victorlous. [S. The Table Spread, A-56].

Therefore, whoever likes to be a victor over his enemies and to defeat his opponents in his concerns about kingship, holding the authority for the like, then he must cling to God-fearing ones, which we have explained above, such as establishing worship, commanding good, forbidding evils, and paying the poor-due. On the other hand, whoever likes the opposite of that, fallure, disappointment and breaking up his gathering and destroying his rule and regime, then he should take the opposite stand and vice versa.

We have been told the following story by our shyikh, our teacher, 
the master, the noble of birth, the saint, the knower of Allah, the educator, the gulde Abu al-Hasan Ali Ibn al-Sayyed Maimun al-Maghribi al-Hasani, may Allah have mercy upon him, may Allah bless us and our dears by him and his ancestors and his descendants. He sald that he has been in Jthad, a crusader, In the way of Allah. That was in Ghamara Land, in the far Maghrib, near the ocean. Our shylkh was born and ralsed there. Then close to or after his attaining puberty, he moved to the c1ty of Fas [Fez] in al-Maghrib. In Fas, there is a sultan, excellent learned men, scholars in Hadith, Quran readers, Fuqaha and others. Our shyikh, may Allah hallow his secret, used to praise that ctity and those scholars. He praised them because of what are there [of good things] such as Allah-fearing and good religion and security for a family and self and money. He pralsed them also, because the judges are abstanants and the ulama, in Fas, are not greedy. They work together commanding good and forbidding evil. They are humble in their clothes, their riding animals and their appearances, so much that he (his shyikh) told us that one of that clty's' (Fas) Judges named sidi Ahmad al-Rahouni, may Allah have mercy upon $h \mathrm{hm}$, was an ascetic toward worldly things and very humble. He says valuable words such as, as our shyikh (Ibn Malmun) reported tt about hIm: Life is pregnant, thou knowest not, it will bring forth, meaning that the events of iffe are not to be trusted. Our shyikh, [Ibn Maimun], may Allah make hị beneficial to people, had visited that mentioned shyikh, al-Rahouni. Ibn Maimun said: "I did not find in his house a mattress except a sheep skin, which he gave to me that night, giving me preference over himself, that he slept lying on the ground and dust." As for the shylkhs of our shylkh [Ibn Malmun] from that area (Eas), if we talked about them, then 
we will need to write another book.

The point is, that this city [Fas] is composed of two parts,

First: The ancient Fas, and secondly is the modern Fas. It is like saying the ancient Masr and Cairo.

The ancient Fez - Allah knows best - was built by the grandfathers of our mentioned shylkh [Ibn Maimun], may Allah be pleased with him, those were our shylkh's grandfathers. They were kings named Idrists, descendants of Idris. Idris is a son of al-Hasan Ibn Ali Ibn Abu Tal1b, from the Radiant Fatima's descendants and her breed. However, our shylkh [Ibn MaImun], as we are going to discuss later, left what he had of worthy things, turning toward Allah with some and all of him. He [Ibn Maimun] was, may Allah have mercy upon him, Ibn Adham and Junaid and Bishr al-Hafl of his time. He (Ibn Maimun) said:

I left Fas when one of our cousins, named All Ibr Rashid, who put himself in charge of Jihad. My purpose of leaving Fas is to flght with him [Ibn Rashid] in the Way of Allah. We remalned a long time. [In Jahld]. The good fortune helped Sid1 All Ibn Rashid to the degree his master became great and big. The Franks and Christlans feared him in that area. His soldiers increased in number and his army became large, Tribes came to him and he became the head of heros and large armies.

We remalned a perfod of time attacking the Christlans who were forsaken by Allah, the Most High. Allah gave us victory over them that we take their women and children as spolls of war. In that period of time, we were carfying out the precious Sharia according to external meanings of the Sharia as much as we could. That was with ourselves and the army and those who have recourse to us. So much the Fez sultan became a kind of jealous person of our dolngs, and the leader of the army, Alf Ibn Rashid. However, we did not pay any attention to that jealousy.

I declded to bring my family from Fas with me to the land of Sidf Ali Ibn Rashid, the leader of the Muslim army, in order to be closer to $\mathrm{him}$. Allah made him agree always on my opinion and never violated those 1imits I made. That lasted for a long time. As a result of that, I was envied by the influencial men in the army. The army became bigger and bigger in number and supplies. As a result of that, increasing some of the low people in the army started violating the truth, that had been spoken 
by the Book and the Sunna. Then I said to myself, as long as this army is practicing the violations of the preclous Sharia and committing sacrilege in these violations, it must fail and be forsaken. Its vell will be torn and its inviolability will be violated. This will be a reward proportionate to the $1 \mathrm{r}$ evil deeds as 1t says in the Quran: "The guardian of an 111-deed is an 111 the like thereof." [S. Counsel, A-40]. I could not leave the army without employing artful means in order to sell my house there and to leave from among them in Allah's peace, which I did.

Only a short time passed unt1l Allah Inflicted the Sultan of Fas on them [the army], who destroyed them. That Sultian made them taste the great might of Allah, whlch had been prewritten for them in the Knowledge of Allah.

That is the meaningful story in brief. I [Alwan] only have told

that story in order to get the attention of the man in charge, the Caliph, on the earth, who should know that life is not to be trusted. The sequel will be for the pious. Allah-fearing to be only by the following the Book and the Sunna by the ellte and the masses. otherwise without following the Book and the Sunna, a wise one should not

feel safe about himself and those close to him, of the Most High saying:

And guard yourself against a chastisement which cannot fall exclusively on those of you who are wrong-doers, and know that Allah is severe in punishment, [S. Spoils of War, A-25].

Also the Great, the Most High sald: "...And let those who conspire to evade orders beware lest grief or painful punishment befall them." [S, Light, A-63]. We take refuge Into Allah from His anger and his plotting.

Analyzing The Ãyah "Those Who If We Give Them Power..."

The second possibility for analyzing the aryah (see page 63),

"Those who if We give them power..." 1s that the relative pronoun; who, is in place of the accusative (the subjunctive) because of the praise by implication. So the àyah will mean, I praise those who if We give 
power, they will do so and so.

As for the nominative case of the relative pronoun, Who, the ãyah would be like if someone asked: Whom does Allah help? then the answer would be "Those wha if We give them power..." meaning they are who if we give them power, they do such and such.

As for Allah's ending of the ãyah with "And Allah's is the sequel of events;" It means all cases go back to Allah, its destiny and its reference, as He sald: "...and unto Him the whole matter will be returned,.." [S. Hud, A-123]. He also sald: "...Allah's is the command in the former case and in the latter..." [s. The Romans, A-4]. Allah used the form of plural, events, in the ayah because their helping Allah is an event, giving them power. In the land is an event, their establishing worship and paying Zakat [alms] and commanding good and forbidding evil are events. All of these events will be returned unto Allah. This implies His command in order to thank Him for His graces, because every grace requires thanking ițs giver." Thankfulness Is to be attributed to Allah as the qualified people for paradise say when they enter it.

... And they say: The pralse to Allah, who hath guided us to this. We could not truly have been led aright if Allah had not guided us. Verily the messengers of our Lord did bring the Truth. And 1 is is cried unto them: This is the Garden, Ye inherit it for what ye used to do. [S. The Heights, A-43].

Therefore, one should say about every grace upon him by the Truth: 0 Allah this only from you, no one else particlpates with you. "Whether those graces are connected or disconnected, sensory or unsensory; world1y or of relating to the Hereafter, and whether they are internal or external, as it is reported in some prayers: " 0 ! Allah whatever 
grace upon me or upon anyone else from your mankind, it is only from you without any participant." Allah knows best.

The Interpretation of The Ãyah "Lo! Allah Enjoineth Just1ce..."

As for the second ayah, that we brought after the first one: The second ãyah 1s: "Lo! Allah enjolneth justice and kindness..." Th1s Is a great ãyah that must be carried out and all other Quranic ãyahs as well. Kings' edicts must be followed chapter by chapter, word by word; letter by letter, and meaning by meaning. Meantime, these edicts must be understood on the whole and in detall, beginning and ending. Even on the assumption that who recelved the kings' edict forsook reading a letter, of that edfct's letters, dropped or lgnored something of the reading, understanding with care and carrying that edict out, the recefver will deserve punishment by that king who issued that edict. Therefore, the Quran is the edict of the King, the Truth; He in Whose hand realm and sovereignty unto whom He will. Then His Book that He issued must be pondered and understood, word by word, ãyah by ãyah, decree by decree, commanding and forbldding. If the given sovereignty did not do that [follow the Quran] then he violates inviolability and its Iimit, and he does not know its glory and greatness. The Most High sald:

(This is) a Scripture that We have revealed unto thee, full of blessing, that they may ponder its revelations, and the men of understanding may reflect. [S. Sad, A-30]. Furthermore He said: "Will they not then ponder on the Qur'an? If It had been from other than Allah they would have found therein much Incongruity." [S. Women, A-82]. He also said: "Wi11 they then not meditate on the Qur'an, or are there locks on the hearts?" 
[S. Muhammad, A-24].

Pondering here means looking 1nto, understanding and carrying out what the decrees of Allah require. Whether the requirements acts or abandonment, giving or depriving, forgiving or punishing, and so forth. So whoever does that is falthful to Allah and His messenger and His Book. On the other hand, whoever does not, he cheats himself. Also he is not faithful neither to his Lord, His messenger nor to His Book. As the Master of mankind sald: Religion is falthfulness. 88 So whoever has no falth he has no religion and whoever has no religion he gets no reward, because judgement means reward as it is in the Quran: "Owner of the Day of Judgement" [S. The Opening, A-4]. Everyone is Judged by the same way he Judges the others. Whoever has no reward he consequently is the loser. The Most High sald;

Say: Sha11 We Inform you who w111 be the greatest losers by thetr works?

Those whose effort goeth astray in the life of the world, and yet they reckon that they do good work.

Those are they who disbelieve in the revelations of their Lord and in the meeting with HIm. Therefor their works. are valn, and on the Day of Resurrection We assign no weight to them. [S. The Cave, A-104, 105 and 106].

This ayah means they do not thank Allah for His signs because the Quran is of His greatest signs, therefore, thank Allah's sending down of the Quran as a means of obeying its 1imits.

Meeting with Allah means that Allah will see people or they will see Him. So, whoever belleves in the lasting [endless] existance of the Truth, he is sure that he will see Allah wherever he is or goes. The Most High said: "Unto Allah belong the East and the West, and whithersoever ye turn, there is Allah's countenance. Lo!' Allah is. 
Al1-Embracing, All-knowing." [S. The Cow, A-115]. "... Nothing and (Naught) is as His 1ikeness..." [S. Counsel, A-11].

His [Allah's], self is never like other selves. His qualities are never like other qualities. He (Allah) is everywhere. He is existing all the time. No one in Himself except Himself. This is the meaning of the meeting if you make it in this world.

But if you make it in the Hereafter, as it is we11-known in the external interpretation, then meeting with Allah, means $1 t$ will be the result of doing good work and serving HIm sincerely. As the Most High sald: "...And whoever hopeth for the meeting with his Lord, let him do righteous work..." [S. The Cave, A-111]. Righteous work means sincere for the sake of Allah.

So doing justice and good to whom is under his [sultan's] rule is one of the best of righteous works.

We have known that the master of mankind said: "Working of a just imam, i.e., a caliph or sultan, with his subjects for one day is better than the working of a worshipper with his family for a hundred and fifty years." Another Hadith says: "Doing justice for one hour Is better than worshipping Allah for elxty years." Also Masruq, may Allah have mercy upon him, sald: "Indeed, being a just judge for one day to me is better than being an invader for the cause of Allah for a year."

Furthermore, Alhasan a1-Basri sald: "Garden of Eden! Ah! what will convey unto you what Garden of Eden is! It is a golden palace which no one can enter but a prophet, truthful, martyr, or a just judge passing his judgements in a loud volce." Therefore, if the Imam, I mean the Sultan and the like whoever rules such as judges and governors, 
if they rule justly their prayers will be answered [by Allah]; because it says in this Hadith: "There are three people whose prayers never should be refused; the just imam, the fasting unt1l he breaks his fasting and the wronged." 89 The messenger of Allah also sald; "In Paradise there is a palace that has five thousand doors: No one can enter. It but a prophet, truthful, martyr, or a just Imam." It is good for the just Imam to be loved by Allah according to the Most High's saylng: "... and act equitably. Lo! Allah loveth the equitable." [S. The Private Apartments, A-9]. As for the unjust ruler he 1s.hated by Allah. According to His saying: "...Lo! He loveth not wrong-doers." [S. Counsel, A-40]. Indeed, He [Allah] will make the unjust ruler a firewood for Hell as He sald: "And as for those who are unjust, they. are firewood for he11." [S. The JInn, A-15].

Therefore, Allah put one in a certain position in order to devote himself to worship only. If one knows his Lord and worships Him in that position, then he is grateful to his Lord. Thanking Allah increases the bounty of Allah upon him.

On the other hand, if one ignores his Lord and does not know Him, and does not devote himself to worship Him in that position, then he is ungrateful for His graces. This will make him deserve a painful punishment.

Thus, an alim's position is spreading knowledge ['ilm] and obeying sineerely. The postion of the learner is to benefit from the ' $11 \mathrm{~m}$ and to inquire.

The position of the governor and the Imam is establishing the tasks he must do, such as prayer and fasting, besides a few of the financlal and physical works of supererogation. Improving himself 
[sultan] first, and-then proceeding to reform his subjects 18 one of the most important duties of the Sultan, a duty which leads him to higher degrees.

The best thing for the sultan to do is to carry out the decrees of Allah and the Laws of the prophecy of Islam.

Thus if the Sultan realizes his duties then he must use what he understands in order to accomplish those duţles honestly and according to his understanding, otherwise, he should consult the trusty Ulama, who wach and fear Allah, who guides kings to truth fighting for the cause of Allah, fearing no biame from any accuser.

As the messenger of Allah sald, "The best jihad is speaking truth to an unjust ruler." 90 And how much more valuable is telling the truth to the Sultan, whom Allah has established in order to destroy the people of injustice. Then it would be the best of the best; because speaking the truth to an unjust ruler results only, in strengthening the word of Allah and supporting and spreading truth. But with the just Sultan, it would result in his knowlng it, following 1t, belng a good example, and so forth.

Thus, whatever causes additional benefits is better than that which does not.

\section{Religious Limits and Punishments}

After the Sultan knows the Law of God in the book of Sunna, and the other rules practiced according to the Sharla, then he must carry out the Law and its rules, because Allah has created him for that purpose. So, it is justice that the Sultan establishes limits, punishments and the like according to the Muhammadan Sharia Law. 
Thus, the Sultan should execute the murderer when the family of the murdered ask for blood and after proving the reason of murder. Before the execution, the murderer should be given a chance to write his will and to ask forgiveness from those he did wrong to, especlally if he asks for that chance. Meanwhile, the executioner must k111 correctly and not torture the executed. The family of the executed and the Musilm public should be allowed to wash and wrap the body, and then pray for him. If the executed was left without washing, wrapping and burying, then the sin of leaving him 11ke that will be upon everyone, Including the Sultan, the governor, the judge, the elite and the masses. This is what our Imam, al-Shafil's sect says, because it is a collective duty. If one Muslim does this [holds a burial service] then the sin will not be common upon everyone otherwise, it will be in case of anyone who knows about it and was able to take the sin off of the people.

It is not the Muhammadan's Sunna to leave the executed, even if he is a disbeliever, for the dogs to eat; and for the people to see his genttals, and his body or to let people suffer from the body's smell.

Indeed it is true that the Prophet threw the bodies of his enemies' leaders, such as Abu Jah1 and his followers, Into the well of Badr." The Prophet did not cover their bodies out of kindness, but he did it in order that the Muslims would not suffer from the smell of their decomposed bodies.

So, anything which does not comply, with the Chosen Prophet's Sunna, is not justice.

The Most High said: "Say, (0 Muhammad, to mankind) if ye love 
Allah, follow me, Allah will love you." [The family of Imrān, A-31].

Punishments of Adultery and Theft

It is justice to establish the limits of adultery against the adulterer and the sodomite, when adultery or sodomy is proven. The punishment of that is beating and exiling the one who has not been married.

Although, as for the one who has been marrled, he must be stoned; then washed, wrapped, and buried. It is 11legal for the Imam, his representative and his judge to Ignore this law or to administrate it only as a threat. Also; It is 11 legal to be partial to someone in this matter who is from the army or of the nobllity.

The Most High said:

The adulterer and the adultress, scourge ye each one of them (with) a hundred stripes. And let not pity for the twain withhold you from obedience to Allah; if ye belleve in Allah and the Last pay, and a party of believers witness their punishment. [S. Light, A-2].

$0 \mathrm{King}$, may Allah support you and help you to administrate His 1imits, 10ok into what this ayah includes. The ãyah orders beating spectfylng it by a hundred in number, in the case of a free adulterer; but in the case of a slave adulterer the punishment would be half of the unblemished. According to what the Most HIgh says in another ãyah, about female slaves: "And if when they are honourably married they commit lewidness they shall Incur the half of the punishment. $"$, [A. Women, A-25].

The purpose of the Truth by Iimiting the punfshment in that number; is that you should not increase or decrease one stripe. If you do then you do not administrate justice. Therefore, do not increase 
or decrease stripes, because in both cases, it is unjust and wrong, which is against the law of justice. As for the stoning of the unblem1shed, tt has been proven in Sunna. It used to be a part of the Quran also, that which comes in the following abrogated ayah: "The adult man and the adult woman, if they commit lewidness, must definitely be stoned," This ãyah has been abrogated 1fteraliy, but not in pract lce. It is justice to do the flogging with a moderste stick, which is neither green nor dry. As for the person who does the stripipg; he should not be excessive in his scourging, which could result in death, because Allah commanded us to $\mathrm{flog} \mathrm{him}$, and not to $\mathrm{kill} \mathrm{him}$.

On the other hand, the striper should not squander provided that beating is not harmful and painful. That mentloned above and the like is justice.

When the Sultan exiles the adulterer, let him exile him for one year, no.more and no less. If the Sultan makes the extle more or less than a year, then he is doing wrong and injustice.

As for the custom that has been exerctsed by some kings, that is ordering castration of the adulterer and cutting off the pents and his testicles, it is wrong, Ignorance, Injustice, and oppression. Whoever does this must not be taken as an example because he is one of the tyrant rulers, who are hated above all by Allah the Most HIgh.

\section{Punishing Highway Robbers}

Also highway robbers are dealt with by the Sultan, according to what the Most High says:

The only reward of those who make war upon Allah and His messenger and strive after corruption in the land will be killed or crucifled, or have their hands and feet on 
alternate sides cut off, or will be expelled out of the

1and. [S. The Table Spread, A-33].

The Sultan penalizes highway robbers according to the interpretations [af the previous ãyah] by the leaders of knowledge [11m] in their written books and their well known schools of Interpretation.

A thief who steals wealth from a fortified place deserves to have his hand cut off according to the rules, which are written in the books of Fiqh. In this matter the Sultan and his representative must not be partial to the thief whoever he may be; whether he is a noble or humble, whether he is from his [Sultan] relatives or a stranger.

The reason for that is that in the time of the master of Mankind [the Prophet], a woman from the Makhzum [a branch of Qura1sh Tribe] stole something, the Prophet ordered her hand cut off.

Her case concerned the Quraish, her tribe, land the Prophet's tribe] saying who could mediate for her with the Prophet. The people of Quraish talked to Usama Ibn Zald, may Allah be pleased with them, in order to mediate in dismissing the cutting off of the 1ady's hand. Usama and his father Zald are loved by the messenger of Allah, but when Usama had talked to him about the case, the bringer of good news, the warner [the Prophet] became angry and that anger was shown on his face.

The Prophet then said to Usama, his beloved, the son of his beloved: "Would you mediate in a 1imit of Allah?" After that, the Prophet made a speech to the people saying:

The former nations were only destroyed because when a. noble steals they leave him; but when the humble does, they cut off his hand. I swear by Allah, if Fatimah, the daughter of Muhammad [his daughter], had stolen [something] I would cut off her hand. 91 
The hand of that woman from Quraish was cut off and she became a sincere repentant.

Thus, this Hadith teaches us lessons, such as Imposing the law: of Allah upon the powerful, the weak, the elite, and the masses:

Also, It teaches us that mediating in order to Ignore the law is 11legal. So, whoever does that is a disobedient to Allah and HIs messenger. If it was not a sin, the Prophet would not have copdemned that which Ușama did. Also, this Hadith teaches us to restrain whoever mediates to impose the limits of Allah even if he is a loved one. Furthermore, it proves the cutting off of the thieves' hands, not slaying them, because Allah the Most High said: "As for the thief, both male and female, cut of their hands." [S. The Table Spread, A-38]. He did not say $k 111$ them. Therefore, whoever slays a thief will be unjust and wrong because he violates the law by golng beyond the limit.

If the thief is too dangerous, then he should be watched. And, if he steals a second time, then his left foot w111 be cut off, in the third time his left hand, in the fourth time his right foot. If he steals after that, he should be rebuked. This is the law of justice and the Muhammadan Sharia. Whosoever violates this will be more knowledgeable of himself!

Yes, If the Imam thinks that he should fail such a person, it would be better than slaying him. Allah knows His devine secrets best.

The Drinking Punishment

It is justice to impose the punishment of drinking upon whoever drinks a forbidden drink, such as wine and so forth. The one who 
drinks must be punished [whIpped], also by threatening hIm that his wealth might be taken away from him. The drinker should also be humiliated that he may repent. Even if he is from important princes and governors, or from the most elite, because, He who makes seeds grow and the winds blow [Allah] sald:

Thou wilt not find folk who belleve in Allah and the Last Day, loving those who oppose Allah and His messenger, even though they be their fathers or their sons or their brethren or their clan. As for such, He hath written falth upon their hearts and hath strengthened them. with a spirit from Him. [S. She That D1sputeth, A-22].

So, $0 \mathrm{King}$, open the hand of your Justice. May Allah strengthen you and increase your power. May Allah support you to enforce the law of Muhammadan Sharia.

Allah has sent and driven you to the most honorable and the best of His land. When He made you the Sultan of the two Holy Mosques in Mecca and Madina, He also made you His viceroy in the holy land. He bestowed upon you the Kingdom of al-Sham, of which the Master of mankind has sald:" "Keep ahold of a1-Shām [Syria] because it is the best part of the lands of Allah; who is the Great and Mighty. The best slaves of Allah 1ive in al-Shām [Syria]..." At the end of this Hadith, the Prophet said: "May Allah betide Syria! They [disciples] said, "wherefore?" He sald: "The angels of the Merciful are spreading their wings over it." 92

Furthermore, our master Abdulla Ibn Musa'ud, may Allah be pleased with, him, said: "God has divided goodness into [ten parts] and He put nine-tenths [9/10] of 1 in in Syria and the remaining one-tenth in the rest of the earth."

Ibn Umar, may Allah be pleased with him, has reported from the 
Prophet that he said:

Before the Day of Resurrection there will come a fire from out of Hadramawt. That fire will drive people together. I said [Ibn Umar]: What do you order us to do? The Prophet sald: Go to al-Shām. Then the Prophet sald: While I was asleep, I saw the plllar of the Book taken from beneath my head. I thought it was taken away [from me], then I traced it with my sight, then I saw it taken to al-Shàm. Truly, when confustions occur, then fatth will be found in al-Shām [Syria].

Furthermore, the Prophet said [about Syr1a];

The right justice for the Muslims will be set in the Day of Justice in a spot called Al-Ghuta, which holds a city named Dammascus. That place is the best place to live for Muslims.

On the whole, Allah has given you power in His land and He settled you in the best of H1s countries. He [Allah] appointed you to fule the most honorable of those countrles; besides what he gave you from the other kingdoms such as the Arabs, Perstans, Romans, Hijaz, Al-Sald, Egypt, and so forth. "So, set thy purpose resolutely for the right religton, before the inevitable day cometh from Allah." [S. Romans, A-43].

This speech was addressed from Allah to the most honorable, our Prophet Muhammad, therefore, it is addressed even more to the others because whoever clings to the Sunna when the community is corrupted; will get a reward, as much as one hundred martyrs. Especially 1n dea1Ing with a drinker of the Mother of Great Sins, the Head of Lewdness, I mean alcohol, which is forbidden by the Book, the Sunna, and the consensus of the [Muslim] community, even more, it is unanimously forbidden by all of the other religions. It is not 11 legal in any [of the fourl religion, because all of the Islamic, Christian, Jewish, and Mazdaian religions belleve in the flve general principles. Those 
principles are: guarding faith, self, mind, honor, and wealth. GuardIng falth against being a disbeliever. Guarding oneself against slayIng a soul unfustly. Guarding honor would be guarding good women against accusations of being bad women. Guarding the mind means being strong willed against drinking alcohollc drinks. Guarding wealth is not to be taken unjustly. Therefore, there fo no doubt that the limits [mentioned before] must be imposed in case of compltting such ginful acts:

If a drinker of alcohol were asked what his religion was and he answered them Islam, then he should be told that he 1,s a liar because alcohol is forbidden in Islam." If he sald, for example, Judalsm, then he is lying because drinking alcohol is not allowed in the Jewish religion. Even if he mentioned all religions he is still a liar about being a follower of any of those religions.

The resuit is that the drinker is not permitted to drink by any religion because alcohol is illegal In all of those religions.

Thus, what a great misfortune in Islam! Verily to Allah we belong, and verily unto Him we return!

By the grace of Allah, may the corrupters be thwarted by our Imam, our master, al-Khudawandgar. May Allah give hIm a lasting support.

\section{Ulama and Farmers}

It is justice, also, to pay attention to the affairs of ulama, ministers and great or small governors, so that he [the sultan] Investigates their affairs such as, spending money on them when they are away from their homes on short or long trips. Everyone of those 
people should be put in his qualified position according to the Prophet's saying: "Put people in their qualified places."93

[Meantime] The Sultan should Investigate the affairs of the common of farmers. Allah has made those farmers a mercy for the ellte and the public by establishing them in planting and growing grains. Those farmers should not be taxed and burdened more than they can afford. Taking [money, wealth] from them should be done in a kind Just way. The poọ and weak of them should not be treated harshly, because such a treatment would make them glve up, leaving the farming, and destroying the farms.

It has been reported that AlI Ibn AbI Tallb, may God honor his face, sald:

The world is a garden and its fence is the Sharia. The Sharia is power that must be obeyed. The obedlance is a policy, which is exercised by a King. The King is a rulex whom the army gathers around." The army 18 a supporter that can be assured by money. Money is a provision which is to be collected. from the subjects. The subjects are masses whom justice binds. Justice is a foundation which the world is bullt upon.

\section{Kindness}

Talking about justice in detalls would make the discussion too long. So, let us talk about Hys saying: "... and kindness..."

There is no doubt that Allah, the Most High, has been kind to us. We were non-existant, then he created us.. We were sperm cells, blood clots and embryos, then He constructed and shaped us in the best stature. We were naked and He dressed us; weak, and He strengthened us; poor, and He enriched us. He, also, gave us uncountable graces and favors, as. He sald: "And if ye would count the favor of Allah, ye cannot reckon it." [S, The Bee, A-18]. Also, He sald: "But bear 
w1th them and pardon them. Lo! Allah loveth the kindly." [S. The. Table Spread, A-13]. Meanwhile, Allah forbld to us aggression as He says: "...But begin no hostilities, Lo! Allah loveth not aggressors." [S. The Cow, A-190]. Furthermore, He sald about kindness: "...And be thou kInd, even Allah hath been kInd to thee." [S. The Story, A-77]. Allah also sald; "Is the reward of goodness aught save goodness." [S: The Beneficient, A-60]. "For those who do good 1s the best [reward] and more (thereto)." [S. Jonah, A-27]. "And who scoreth a good deed, We add unto its good for him." [S. The Council, A-23]

It is goodness that the Sultan conceals within his heart, good and honesty for the subjects, whether they are common or elite, rich or poor, powerful or weak, and whether they do good or bad. As the Prophet advised whoever may be his successor: "Let him accept from them what they do right, and pardon those of them who do wrong."

Meantime, Allah ordered the Prophet to do the same thing in dealing with His enemies, when He said:"

Thou wilt not cease to discover treachery from all save a few of them. But bear with them and pardon them. Lo! Allah loveth the kindly. [S. The Table Spread, A-13].

People of Mecca were the extremest enemies of the Prophet. They treated him in the cruelest way. They drove him away from his city [Mecca]. They murdered his disciples and his relatives. They cracked his head and broke his tooth, making him bleed. They intended to jail him, k111 him, or drive him away from his home as the Most High gald: "And those who disbelieve, plot against thee (o Muhammad) to wound thee fatally, or to kill thee, or to drive thee forth..." [s. The Spoils of War, A-30, p. 141]. 
However, on the day of the conquest of Mecca, when the Prophet had the power over the people of Mecca, when Allah fulfilled His promises to the messenger by defeating the people of Mecca, and giving the Prophet victory and support over the people of Mecca, when that accurred, the Prophet asked the Quraish, saying: "Now what do you say [of me]?" Then they safd: You are an honorable brother and an honorable cousin. Then the Prophet said: "I say to you as Youseph said to his brothers, 'Have no fear this day." [S. Joseph, A-92]. After that the Prophet said: "Whoever stays in his own house will be safe and whoever enters Abu Sufyan's house w111 be safe."

This Abu Sufyan, may Allah be pleased with him, was, before he became a Muslim, the head of the disbellevers in the Uhud Battle (between the Muslims and the disbellevers). Th1s was Abu Sufyan who gathered [clans] against the Prophet. However, the Prophet did not return the 11ke [retaliate] for anything but he sald: "Have no fear in this day." The Most High sald: "Verfly, In the messenger of Allah, ye have a good example." [S. The Clans, A-21].

The Sultan and the Poor People

It is kindness that the Sultan should send supplies and monies to the Muslim poor and powerless throughout the Empire. The Sultan should appoint a good sincere man, who fears and hopes Allah [forgiveness], on the purpose of distributing those monies and supplies in every town and every section of town. The distribution should be according to those sections and town's needs. Those poor and powerless people are the real army of which each of their arrows [prayers] to distances as far as five hundred years, a thousand years, and many 
times those numbers of years. The soldiers which are stationed for fthad: [holy war], the arrows of each one of them goes as far as the eye can see and further. But as for the weak, the poor, the widows, the orphans, and the [cut off] broken people, they will be happy about the Sultan's aid. May Allah glve him [Sultan] victory. Also their hearts will be full of Joy; whtch will make them, in their religlous concentration and disclosure, day and night, say from the bottom of their heart: "O Allah!, support our master the Sultan. O Allah!, support him with angels. o Allah!, do kindness to him..." and so forth.

So, what would you [the Sultan] think of the reaction of a widow, a poor person, a needy person; a seeker of $11 \mathrm{~m}$ (knowledge), or one turning his face sincerely to Allah when [you] bring joy into their hearts? "What would you think of those people when they alf pray to $\mathrm{Allah}$, the Mighty, the Great, for you, when those sincere prayers are In the right time, coming from broken hearts, when the Truth is close [epough] to them to answer their prayers, I wonder if Allah would thwart their work or reject their prayers! Would you think Allah would disappoint whomever does kindness to those broken hearts or whoevex supports thelr yearning. Allah forbid (rejection of those prayers) whose generosity is far above.

One of the great awlyas [Saints] was sick because of a urination problem, which made him go to Quranic schools for children, asking those children, "Pray for your uncle, the lier." Whereas before, prayer used to be requested from him: [by people]. So, I urge you [the Sultan], in the name of Allah, to hasten to this goodness and to aspire for doing kindness, and take the opportunity for benefitting 
from the poors' prayers. The messenger sald: "Mankind is the children of Allah; therefore, the most loved by Allah are the most helpful to Allah's children." 94 Also, the messenger of Allah said: "Every good deed is a charity." 95 Furthermore, the Prophet said:

Bringing foy into your Muslim's heart by feeding him or by relleving him from distress, is one of the causes for forgiveness [by Allah].96

There is no distress greater than the situation of farmers and the like who are oppressed by inspectors, annoyed by the Sultan's men . and soldiers. So let the honorable edicts be issued in order to remove wrong and harm. Then the hearts of the oppressed w111 full of foy when they hear about these edicts.

Therefore, the only reward for that matter, which caused great joy to the people is that the heart of the man in charge, the Sultan, will be full of joy, because Allah will be pleased with him: "For the 1ike of this, then, let workers work." [S. Those Who Set The Ranks, A-61]. "Whose seal is musk-for this let (a11) those strive who strive for bliss." [S. The Defrauding, A-26].

Pour forth your justice to cure wronged souls (hearts). Do goodness in this 1ife for your own benefit, whatever you can. You can Imagine this life turning away from you, the same as it țurns for you from the others.

The Sultan and Concealment

It is kindness to help a yearning and to meet people's needs. An honest, kind, compassionate man should be appointed [by the Sultan] in order to meet the needs of Allah's slaves. In doing this, if you [Sultan] prefer having concealment like some Caliphs did, then 
you may, but if you condescend by being unconcealed, then that would be perfect and the best [thing to do], because as the Messenger said:

Whomever Allah puts in charge of the Muslims' affairs then he conceals himself from their needs and poverty, Allah will conceal Himself from that person's need and poverty in the Day of the Judgement.

The Messenger also sald:

Any governor or Judge who closes hls door tintending to prevent poor, needy people from reaching him; then Allah w1ll close His door, preventing that person's poverty and need from being answered.

May Allah protect us, and you, our KIng from that.

\section{The New Judicial System}

It is kindness to provide judges and the State employees with money from the Public Treasury, which will make IIving for them and their children as it was in the past. This would enable everyone to have their right. Some people may need to reglster some of their affairs in the court for Instance, in order to have that done, people have to ask a judge to write a judgement paper, which is to be a document in their hands; but the previous laws which used to be practiced by the judges are not in existence anymore. As a result [of the absence of this law] people wili resist paying for their documents at times; because of elther greed, poverty, or deficlt. As a result of that, many people will lose their rights. Th1s situation was nonexistant in the past, especlally in the time of the Prophet, and the wise Callphs after him, and so forth, up to the time of our nearest past. Yes, there was the evil corruption, and the forbidden bribery In the time of that tyrant state. Allah has removed generously, that evil by bringing to these kingdoms the happy caravan [of the Sultan]. 
People are annoyed by the [new] hard judiclal law only because it is very difficult to leave what they are used to. They used to register their marriage contracts wherever they want and with costs as much as they could afford. They used to register their documents wherever they want and without any difficulty. But when the [new judfclal] law came, it seems that people did not like that law, denouncing it privately and in public. People will also denounce taking that certain amount of money from the dead people's wealth [taxes] by those in charge of this matter [the fudicial system]. This might result in taking something out of an orphan's wealth. Although, in that time [Mamluks', time], unjust rulers would take money unjustly, as many times as that mentioned amount, but, they did not take anything from. dead people's money, or from the orphan's wealth. Therefore, the just authority in this state [the ottoman] is a kind one. It shelters the powerful and the weak. Judges justify taking that money with their need for money to spend. Thus, if that mentioned habit cannot be changed, then we hope that Allah make the man in charge lessen that Kharaj, I mean, that money which is taken in that way. This would result in common goodness and an increase of support by prayers. Success is granted only by Allah. We have said this for the purpose of Information and mediation, obeying the Prophet's saying: "whoever medlates for people, then, he will be rewarded by Allah." 97

We have mentioned this for the purpose of objection or denouncement:. We ask forgiveness of Allah, and repent to Him from what displeases Him. 
Awqaf

It is kindness that the Sultan take care of awqaf [endowments], such as schools, Khwanlq [Suft monastery], ribats [army stations], routes, streets. The facilities and proceeds of those awqaf should be used according to the endowers w111.

Allah, the Most HIgh sald: "He only shall tend Allah's sanctuarles who belleveth in Allah, and the Last Day." [S. Repentance, A-18]. Also, the Most H1gh sald: "That (1s the command), and whoso' magnifleth the offerings consecrated to Allah, is surely from devotion of the hearts." [S. The Pilgrimage, A-32].

Tending Allah's sanctuaries means locking the doors except at prayer time. Tending also means protecting them from impurities and dirt. It also means preventing children, crazy people, and tempting women from entering Mosques, especlally when they cause corruption and disturbance for the mosques. Also, preachers and lectures should be reprimanded for allowịg unveiled women and men to intermingle at the gathering, because, that is forbidden.

A Muhtasib of good and forbldder of evils should be appointed. That person should be a scholar and if he is not, then he should ask the scholars and fear Allah. The responsibilities of the commander of good should be to supervise in public baths to prevent people from uncovering their genitals. He should make certain that the people perform Friday prayers on time. He is also responsible for watching merchants and must not tolerate any evil selling or false measuring of things. The most Important of his responsibilities is not to do wrong to the merchants by taking bribes or sales taxes for corrupted reason. Even though commanding good is in existance (in those days), but 
requirements are missing, it is required that the commander of good is to be knowledgeable, patient, kind, honest, asthetic, smart, clever, wise, and impartial to no one. But how rare this type of person is!

\section{Kinsfolk}

$\therefore$ There are many types of kindnesses. So, whoever works according to his knowledge of kindness, then Allah will teach him things he has no knowledge of. 98

As for His, the Most High's saying; "And giving to kinsfolk" [S. The Bee, A-90] it is possible that Allah means by "kinsfolk" the Prophet's relatives such as Ashraf and Sadat [Nobles and the Masters, descendants of al-Hasan and al-Husyan]. It also includes the descendants of the Emigrants, The Supporters, knowers of Good Saints, and scholars, because Moslims are close relatives. The Prophet said:

Whoever belleves In. Allah and the Last Day, let him be kind to his relatives. Whomever it pleases that his sustenance should be make ample to $h 1 m$, or that his life should be lengthened, let him be kind to his relatives.

So, the man in charge should care about the descendants of the Prophet and descendants of the others mentioned above. Let him provide them with what they need. The Most High sald: "Say (O Muhammad, unto mankind) I ask of you no fee, therefore, save loving kindness among kinsfo1k." [S. Counc11, A-23, p. 346].

As for His saying: "And forbiddeth lewidness and abomination and wickedness..." [S. The Bee, A-90].

Lewdness includes any crude words, behavịor or crude manners. So, [the Sultan] should give orders for punishing whoever speaks lewdness, as some ignorant followers of princes have done when they push or quarrel with Muslims, and call them disbelievers and Yeaz1d1 [devi1 
worshippers] which is harmful and lewd. Allah, the Most High, said; "And those who malign believing men and believing women undeservedly, they bear the guilt of slander and manifest sin." [S. The clans, $A-581$

So; what the Sharia rejects is abomination. Outrage [wrong] is. violation of the limits of Allah, such as those who discredit their enemy by telling a prince; minister, or an army judge, slander about them, In order to get their enemies harmed by the honourable authority. That persion is called a slanderer and triple because, he destrays three people, himself, the person he discredits, and the one whom he misinforms.

Therefore, an ev11-11ver must not be believed, for as the Most High sald: "O, Ye who belleve! If an evil-liver brings you tidings, verify.it, lest ye smitè some folk in Ignorance and afterwards repent of what ye did."! [S. The Private Apartments, A-6].

Temptation of the Life of the Worid

As for talking about the third ayah, which tells the story of Joseph: "O my Lord, thou hast given me (something) of sovereignty..." [S. Joseph, A-101].

This ãyah indicates that a king must admit to Allahship [to Allah], which is the grace of Allah [upon him]; because without being a slave of the Truth, the king would not be able to have the people obey him. This ãyah also indicates that the king should ignore his power and strength, clearing himself of that for Allah, because, he [the Sultan] has no power, no strength without Allah. The king should admit that the power that he has is a bounty of Allah upon him, and 
that he is strong only because of Allah. The king should not say to himself: "I have obtained all of this sovereignty because of my power, my strength, my soldiers, my followers, and my cleverness." If he says this, then he is ungrateful to the grace of Allah, which would result in quick destruction. We take refuge into Allah.

If the KIng Ignores Allah, not mentioning His name; the devil accompanies hIm, and Allah will turn away from him. On the contrary, If the king refers this grace to 1 ts originator, and if the king sees that these graces come from the Giver, Allah, by His power and His bounty, then he [the Sultan] is thankful and heading towards Allah. As the king thanks the grace of sovereignty, he should; also; thank the grace of knowledge, as Joseph, the truthful, peace upon him, did when he sald: "... and hast taught me (something) of the interpreta-. tion of events..." [S: Joseph, A-101].

Joseph asked Allah the motives for a lasting sovereignty because he was certain that this sovereignty was given to him wouldn't last. forever, because it' didn't for the former [Kings].

Also, the king should always remember Allah; the Most High, thanking Him for His graces, thinking of how life is going to result, because, if 11fe gives joy, it will hurt, if it turns toward one, it will turn away from him, if it makes [someone] smile, it will make him cry. As it has been said about life:

-It is the 1ife which says loudly; be aware, be aware of my assault and assassination. -Do not be decelved by my smile; because my words make you laugh, but my actions will make you cry.

That is why our Master [Allah] warned, us to keep away from it. He also applies proverbs to us revealing its reality, when He said: 
"Let not the life of the world beguile you." [S. Luqman, A-33].

"Your wealth and your children are only a temptation..." [S. Mutual Disillusion, A-15].

Know that the 11 fe of this world is only play and 1dle talk, and pageantry and boasting among you and rivalry in respect of wealth and children; as the likeness of vegetation after rain, whereof the growth is pleasing to the husbandman, but afterward it drieth up and thou seest it turning yellow, then it becometh straw. And in the Hereafter there is grievous punlshment, and (also) forgiveness from Allah and His good pleasure, whereas the life of the world is but a matter of 1llusion. [S. 'Iron, A-20].

Also, the Prophet calls the life of this world a cadaver and he said: "The life of this world is cursed and what is in it too, except remembering Allah and things related to that, such as scholars and students." It has been said that this life is a plantation for the Hereafter.

How wonderful he is who sald the following statement:

Tomorrow all souls will be given what they obtalned. -And the planters will harvest what they had planted.' -If they did good work, then that will be for their own benefit. -If they did not, then what a bad job they have done.

The more deserving thing to be planted [in this life] by the king is justice and kindness for the subjects; because fustice wi11 raise him [the king] tomorrow [Hereafter] on pulpits made of light, in the shade of the Merciful's Throne. On the other hand, doing kindness [to the subjects] will increase the bounty of Allah upon the Sultan, which Is the looking at His Honorable Face, as it says in the Quran: "For those who do good is the best (reward) and more (thereto)." [S. Jonah, $\mathrm{A}-27]$.

Therefore, o king, may Allah combine for us and you the two. soverelgnties, the worldly one, and the one of the Hereafter, I urge 
you to understand the meaning of sovereignty. I do not mean by soverelgnty taking over lands and people, but I mean having control over self and lust, as it comes in some prayers, which say: "SInce you [A1lah] possess me, then give me the power to possess myself, because You [Allah] are the King, the Strongest."

Therefore, the real King is the one whom Allah glves the power to control himself and his degires, even if he 18 one of the weakest and poorest people.

However, if he is one of the nobles and most diatinguished people, then that would be more goodness and grace.

A slave [of Allah] cannot be a real king unless he obeys the law of Allah, the Truth, the Most High, the Greatest. Also, that king must follow the glorious Book and the honorable Sunna in his [the king] speeches, acts, behaviors, and his fudgements whether they be private or public. The king should not follow the example of those of whom Allah has said: "And when it said unto them: follow that which Allah hath revealed, they say: We follow that wherin we found our fathers." [S. The Cow, A-170]. Also, Allah sald [about that type of people]

And when it is safd unto them; come unto that which Allah hath revealed and unto the messenger, they say; Enough for. us is that wherin we found our fathers, what even though their fathers had no knowledge whatsoever, and no guidance. [S. The Table Spread, A-104].

That is what the disbelievers, in a1-Jahiliyyah [pre-Islam] had said: "The only one who follows those people's example is an ignorant, such as the former, unjust kings [Mamluks] after another." Those former kings found their fathers, masters, or tyrant kings before them, had created evil innovations, making corrupted, wrong, and useless rules, which are illegal according to the Book and Sunna. 
However, those klngs followed these 1 llegal rules, then they were destroyed just as their formers had been. The Most High sald: "And (a11) those townships! We destroyed them when they did wrong, and we appointed a fixed time for their destruction." [S. The Cave, A-60]. Similar to those people, there are in our time and before some folks who claim knowledge, poverty, and righteousness; but they found their formers, Shyikhs and the like; following Innovat fve laws and directions. However, the latter follows the example of the former. Therefore, those people are judged justly by this following ãyah: "...Lo! We found our fathers following a religion, and we are guided by their footprints." [S. Ornaments of Gold, A-22]. Another âyah In the same sura says: "...We are following their footprints." [A-23]. Further: the Most High sald: "(and the warner) sald, What, even though I bring you a better religion than that, ye found their fathers following." [S. Ornaments of Gold, A-24].

So, the clever, wise person is one who thinks of himself in order to know that Allah did not send His Book down to be in valn. Also, He. did not send His messengers as playthings, He only sent. His book and messengers for the purpose of establishing the Religlon, following truth, and obeying commands and restrictions, Whosoever does this, will be happy, wise, successful, and a winner too. And whosoever does not, will be driven away to become unhappy and a faliure, whoever he may be, whether from the elite or from the masses; because the Most High said:

And the Book is placed, and thou seest the guilty fearful of that which is therin, and they say: What kind of book is this that leaveth not a small thing nor a great thing but hath counted it? And they find all that they did confronting them, and thy Lord wrongeth no one. [S. The Cave, A-50]. 
It is known that the Prophet died after he had made it [his way] clear and white, as the Most High said. "This day I have perfected your religion for you and completed My favour unto you, and have chosen for you as religion, al-Islam." [S. The Table Spread, A-3].

The reality of Islam is the rejecting ruling [people] by lust and destre. It 18 obeying the Book and the Sunna as the Prophet said;

"No one of you can be falthful unless your desires are in accordance with what I have brought [to you]."

This is the way [following the Book and Sunna] of the master of the formers and latters, which was followed by the wise Caliphs such as the truthful [Abu Bakr], the Distingulshable, [Umar] Uthman and Al1, may Allah be pleased with all of them.

It has been reported about Abu Bakr, may God be pleased with him, that he said, when he became a Caliph:

0 , people, I have become in charge of your affairs. This does not mean that I am the best one among you; but the Quran has been sent down, and the Prophet, peace and blessing upon hIm, has created the rules. The Prophet taught us that the best wisdom is Allah-fearing, and the worst foolishness is wickedness. The strongest one among you is the weakest until I give his right. On the other hand, the weakest one is the strongest until he gives people their rights. 0 people! I am only a. follower [of the Sharla] not an innovator. So, if I did good work, then help me, but if I deviate [from the Sharla], then discipline me.

We know about Umar Ibn al-Khattab, may Allah be pleased with him, that when he became the successor [of Abu Bakr], people dreaded him so much, to the extent that they avolded sitting in the yards [gathering places l. When Umar knew about that, he gathered people, then, to address a speech to them. He sat at the pulpit on the same step that Abu Bakr used for making his speech to the people. Then he [Umar] said, after he praised Allah and blessed the Prophet: 
It has come to my knowledge that people fear my strength and my rudeness saying: Umar was difficult for us while the messenger of Allah was alive, and then Abu Bakr was our ruler, who was between us and Umar, [and now] how much more difficult he will be after he has become the man in charge of our affairs.

Umar continued to say:

Whoever sald that is right. I was with the messenger of Allah, peace and blessing be upon him, serving him until he died, He [the Prophet] was pleased with me, thanks to Allah; I am happy about that. Then Abu Bakr became the man in charge of the people's affairs. I was his aid and his servant mixing my strength with his gentleness. I was a drawn sword unti1 he [Abu Bakr] sheathed me or left me [aside]. He [Abu Bakr] died and was pleased with me, thanks to Allah. I am happy about this. Now, I have become the man in charge of your affalrs. So, you should know that my strength has been Increased but only to those who do wrong and violate Muslim's rights. As for those who are peaceful and good, I will be more gentle than they are to each other. I would never let any one do wrong to one another, or to be violent to one another. I would make the wrong one put his cheek on the ground, then I would put my foot on his other cheek until he submitted to the truth. I commit myseif not to take anything from the people's allowances [which come. from land tax], and if those allowances come to me, I will spend them only Justly. It is your right not to be sent to dangerous places. When you are absent [for Jihad] I will be the father of your children until you return.

Umar, may Allah be pleased with him, kept his promises. He exercised strength and gentleness at the right time. He was the father of chlldren. He would go to the women whose husbands were absent, askIng them if they needed anything, so he could buy it for them. Those women sent their maids to the market [with Umar]. People would see Umar going to the market with many of those women's maids and servants to buy for them [the women] what they needed. If one of those women did not have the money, then Umar would pay from his own pocket, may Allah be pleased with him.

As for Uthman, may Allah be pleased with him, who was kind to his subjects, when he became the Caliph, his humbleness and kindness to 
them Increased. aI-Hasan said: "I saw Uthman [the Caliph] sleeping in the mosque, putting his wrap under his head [as a pillow]. When people came to see him, he would sit with them as an equal, one after the other." Uthman used to take naps in the Mosque; and pebble marks could be seen on his side. People would say when they saw him [In that condition ];

This is the commander of the falthfull He offers people fancy food, but he eats [h1s food] with vinegar and oll. He preaches for the Friday prayer, wearing a garment which 18 worth four or five dirhams.

Once, Uthman pulled his slave's ear, then he ordered the slave to retaliate against him telling the slave to: "Pull my ear hard. How great it is to have worldly retaliation and not retaliation in the Hereafter."

The standard of living increased during his [Uthman's] time because of his good will towards his subjects. Also, wealth increased so much that a slave girl was once sold for as much as her weight in dirhams. Also a mare was once sold for one hundred thousand dirham, and a palm tree sold for one thousand dirham.

Ali, may Allah honor his face, asked for Uthman's permission to fight the Uthman's beslegers, but Uthman refused, saying to All: "I ask, In Allah's name, that if anyone sees Allah as the Truth and thinks that he owes me an obligation, not to shed a cupful of blood of his or anyone else's blood for my sake." When' Ali repeated his request, Uthman's answer was the same. Then Ali sald: "O Allah, You know that we have tried our best." Then the insurgents stormed Uthman's house. They hit him while the Quran was in his hands, [reading it]. His blood spattered on the following ãyah: "...and 
Allah will suffice thee (for defence) against them." [S. The Cow, A-137]

As for Ali ibn Abi Talib, we know that he was humble and rellgiously pious. He was kind to his subjects. He used to say: .

I am a prophet. I do not receive revelations. I follow only the Book of Allah and the Sunna of His messenger as much as I can. Therefore, whenever I command you to obey [Allah], then you must listen to me whether you like it or not.

He used to walk in the streets plcking up lost sandels, laces, then tossing them back to whomever (they belonged). He would direct people who were lost and help porters, reclting the following ayah: "As for that Abode of the Hereafter, we assign it unto those who seek not the oppression of the earth, nor yet corruption." [S. The Story, A-93].

He used to put a handful of ground barley in a bowl, then add water to it, and eat it as a meal. His garment was worth three dirham. The sleeves of this garment were too short to reach Ali's wrist. However, All would say "thanks to Allah for this grace."

When the Public Treasury became full of gold and silver, Alt called on people, then he gave the gold and silver to them saying: "O the white! 0 the yellow! Decelve me not. Here! Take it, take it!" unt1l there was not a dirham nor a dinar remaining. After Ali emptied the house of the treasury, then he prayed two rakas there, in order that place [the house of treasury] would be a witness for him in the Day of Judgement.

I [Alwan] say what AlI did with that money, which was collected legally, should be taken as an example when we are dealing with those matters that are mixed with illegality and judicial errors, such as 
taxes, the selling of wine, protection, and so forth.

May Allah have mercy on whomever knows what to do and to whom [Allah] he presents his works! Would plan [for the Hereafter] something ahead of time in his present life on this earth, listening to the Most High's saying: "This day no soul is wronged in aught, nor are ye requited aught save what ye used to do." [S, yasin, A-53]. Fearing the length of what could have been sald, we would have said much more about their [Umar's, All's, Abu Bakr's, and etc.] blographles, and their qualities and their k1ndness and gentleness to their subjects. May Allah be pleased with them and may He make them sat1sfied.

\section{$\underline{\text { Kindness }}$}

Now let us return to that ãyah we left [before] and talk about it again. That ãyah Is about the story of Joseph, peace and blessing upon hIm, which says: "O my Lord, Thou hast given me (something) of soverelgnty and hast taught me (something) of interpretation of events.". [S. Joseph, A-101, p. 181].

As Joseph admitted Allahship to his Lord, and described himself as a slave of Allah, then we say that the other kings of this world must not forget this [Joseph's] admission and acknowledgement. If the king knows that he is a slave among the slaves of his Master and his Lord, Who have made him kindly a distinguished person, and Who have favored him with power and soverelgnty in the land; then, he [the king] should be just as kind in return. According to His, the Most High's saying: "Is the reward of goodness aught save goodness." [S. The Beneficient, A-60]: 
If he [the King] is king and good to the subjects, Allah would increase glory, kindness, and goodness for him, as the Most High sald: "And whoso scoreth a good deed, we add unto 1 ts good for h1m." [S. Counse1, A-23].

Allah would also protect him from his worrles about the present worldly affalrs and those of the Hereafter. Allah would help him and give him good fortune and victory. Why should it not be so since the Most HIgh sald:

And whosoever keepeth his duty to Allah, Allah w111 appoint a way out for him. And will provide for him (aquarter) he hath no expectation. [S. Divorce, A-2, 3].

"Verily Allah helpeth one who helpeth Him:" [S. The Pilgrimage, A-40]. "If ye help Allah, He will help you.", [S. : Muhammad, A-7]. "If ye keep your duty to Allah, He will glve you discrimination (between right and wrong)." [S, Spo11s of War, A-29].

Discrimination may imply victory, [according to Alwan].

So whoever favors a valid victory; defeat; conquer and success over his enemies, then he should treat his subjects kindly, whether they are the elite or the public, or his armies; whether or not they are private or general. The reason for this is that the Prophet prayed to Allah to be kind to whoever is kind to his (the Prophet's) community: On the other hand, the Prophet prayed to Allah to trouble those who cause trouble in the Prophet's community by harming them, Imposing on' them that they have not the strength to bear it; or ruling them with contradictions towards the Book and the Sunna. Therefore, you [the king] should selze the opportuntty from the prayer of your Prophet, Muhammad, peace and blessings upon him. Do not look at people in a way "that you are a king and they are your "subjects, but look towards 
them as each of you are; created by Allah. Allah brought you, and they, forth from the same beginning, and created you and them from a single soul. You and they are servants of the same Lord, and the slayes of the same King. If He wants to give them the power and take it away from you, He has the power to do that. Also, He can enhance the importance of them and lower the Importance of you. But, because of His devine generosity to you, and because of His latter bounty upon you, He made you distinguished. He appears in you as the King, the Greatest, the Conquerer. If you offer plety, goodness, or rule fustly, then He will appear in you again as His names; the Just Ruler, the Bestower, the Benefactor, the Giver.

So, whatever situation you [0, Sultan] know Allah who put you in this position in order only to know Him. When you [the Sultan] know Him, then you will enhance HIs Greatness, love Him, worship HIm, thank Him and obey His command. Also, when you [the Sultan] do good to His slaves, His creatures, you w $\$ 11$ be doing good to yourself; because. when someone does goodness to others, he should not imagine that he is. doing goodness but to himself. No, indeed, dolng goodness from one to. another is only done by His Lord alone. The slave [of Allah] through whom goodness occurs; does this to his own soul, as the Most High sald: "(saying) if ye do good, you do good for your own souls, and if ye do. evil, 1t is for them (In Iike manner)." [S. Children of Israel, A-7]. When I [Alwan] say, "He appears;" I mean His qualities appear to His slaves in you [Sultan], not only that, but He appears in you for yourself, as He sąld: "And (also) in yourselves, can ye then not see." [S. The Winnowing, A-21].

However, no one should understand from what I have just said, 
that I belleve in Allah dwelling in everything. Also, I did not mean that nothing dwells in Him. Nothing can blend with Him, and He never blends with anything. Nothing is as His 1ikeness [At any rate] revea1ing the secret of the spiritual transformation does not fit in this shortened book. Besides, it is not our concern, this is only something that Allah made take place in the tip of the tongue of the [author's] pen.

The Sultan's Adviser

After the king identifies himself as the slave: of his Lord, and acknowledges Godship as belonging to his Lord, then he [the 'king] is still in need of Him more than the people need a king.

The sultan needs his Lord in every case and in all clrcumstances; because being a king or a sultan is a very dangerous job in this world and In the Hereafter. Thus, our Prophet, peace and blessings upon him, had bodyguards to protect him from his enemies until Allah sent down the following ayah: "Allah will protect thee from mankind." [S. The Table Spread, A-67].

The Prophet, then, stopped using bodyguards. As for other people, unlike the Prophet, have to have bodyguards [such as the king] to protect them from the Immoral and Intangible enemies. So, because kings may not Ignore the evident protection, then let us direct the attention of whom Allah has honored with sovereignity from the Immoral enemles, because those kinds of enemies present a greater danger towards the kings sovereignity. Among those enemies are the devil, whose hostility against people is declared by the Book of Allah's warning of him. Also, there is the human soul that enjoins evil as it is described clearly 
by the Book and Sunna. The Prophet said; "The worst one of your enemies is your soul, that is between your ribs". 99 The previous hadith could be reported in simflar meaning. Those who protect kings from those enemies are sincere [counc1ls] and truthful ministers, who give preference to the Hereafter over the present world. The devil hastens to corrupt a king's soverelgnity and destroy the power of a sultan through his [the sultan's] ministers and close princes, especially when they [the ministers] give preference to the bargain of this Iife over the bargain of the religion. The devil does not fall to come to the ministers through the door of greed, bribary, flattery, hypocrisy, and neglectful advice to their king and sulțan. They are easily persuaded by raritles and gifts, and prefer exquisite objects and presents. They like to take these things from the subjects, masses and elite. They hide advics from the king, which results in the corruption of the sovereignity and in broken laws. We take refuge in Allah. Such an action is taken by some people because of worldly things. Thus, our Prophet, peace and blessings upon him, condemned strictly the behavior of some of his employees. The Prophet sent a man to collect alms and when that man returned with the money, he said; "That is for you and this is given to me as a gift." Then the Prophet became very angry. He made a eloquent speech saying; "Why does not he stay in his father's and mother's house in order to see if there is anyone who could give him gifts". The Prophet stated that whoever among the employees, including ministers and governors, takes a gift, then he will, in the Day of Resurrection, bring that gift, carrying it on his shoulder asking we [the Prophet] to intercede for him, than I would say: "I would not protect you from the punishment of Allah." 0 , the King! May Allah 
strengthen you, look into the Balqis [Queen of Sheba] decelvement of Solomon. Look how she tried to deceive him by sending him a present, as Allah spoke about her when He said: "But Io! I am going to send a present unto them, and to see with what (answer), the messengers return." [S. The Ant, A-35].

Balq1s meant that If Solomon had accepted the present, then he would have been a deceived king, decelved by the ornaments of the life of the world. So whoever is 11 ke this then, he w111 not be the sequel of the heavenly Home, because the sequel w1ll belong to those who do their duties to Allah. But if Solomon did not accept the present; then he must be a messenger of Allah and close to Him. Thus, no one can fight and struggle against. the messengers of Allah. When the Balqis's envoy came to Solomon, Solomon sald as it is reported in Quran: "What would ye help me wealth?" But that which Allah hath given you." [S. The Ant, A-36]. This is the duty of the king, his ministers, his army's judges, his army's leader and his advisors, not to pay attention to presents and those who offer them; especially in these corrupted times. How many times right were held down; and blood and honor and so forth wasted by dirty, sinful, cursed, tyrant kings, and sultans! When their [mentioned kings] followers, door keepers, advisors, and their army's judges saw them in this condition, then the followers hastened towards greediness, murdering the religion of Islam, turning down the 1ighthouse of the Book and the Sunna. The Most High sald: "So of the people who did wrong, the last remnant was cut off, Pralse be to Allah; Lord of the Worlds!" [S. The Cattle, A-45]. Therefore, the king, his ministers, his army's judges, and his advisors, must not be deceived by presents. Indeed, they should say to those who try to deceive them as 
the Prophet of Allah, Solomon, peace and blessings upon him, said:

[to the Balqis envoy]:

What would ye help me with wealth? But that which Allah hath given me is better than He hath given you, Nay it is ye (and not I) who exult. In your gift. [S. The Ant, A-36].

Thus, see [readers] how Solomon profitted from his virtuousness and his sincere asciticism. Balqis and her army became obedient to Solomon and under his power. Furthermore, Solomon succeeded in having Balqis as his wife. The Balqis's army became followers of Solomon and her throne became a yakht in Solomon's house.

So, Allah did not present those ayahs on the purpose of play and vanity, but, He mentioned them [to us] only to learn a lesson from them and to teach us, as He said: "In their history; vertly there is a lesson for men of understanding." [S. Joseph, A-111]. Thus, if the king is virtuous, then his subjects, the elite and the public, will be the same. This is what one of the disciples [of Muhammad] told Umar [Ibn a1-Khattab], when Umar received the wealth of the defeated Khosrau [designation of the Persian Kings]. Umar recelved that wealth complete; in the exact. amount and condition [as was taken in the defeat], which made Umar exclaim: "Whoever delivered this to us is strong and trustworthy,": Then it was sald by him [by that disciple]; "When you become virtuous, then they become like you."

\section{Acceptance of Gifts By Official Authorities}

If it is said; "Did not the Prophet accept gifts from kings, etc, and you [Alwan] command [People] to follow him?", then the answer should be as follows; There is no doubt that the Prophet, in his acceptance and rejection [of gifts] was following his Lord's commands, prałse to Him. 
The Prophet would accept [gifts] with permission of Allah, for the benefit of the presenter of the glft and so forth. The Prophet never accepts [gifts] because of his own desire or preference of the present life of the world, forbid it from him if he did so.

So, whoever is in a position that enables him to understand from Allah, the Most HIgh, the acceptance and the refection, then he could accept and reject according to the divine permission. [On the other hand], whoever does not reach that position, then the refusal [of gifts] is safer in his case, espectally, if the present is as good as a bribe, a couse for cheating or hiding an [honest] advice from the king and the imam, then this would be forbidden, forbidden, forbidden... like carrion and blood and gwine flesh.

[At any rate], whoever read this advise, he is free to take it or leave it.

A lesson can be taken from the Story of Solomon which is this; it is more and more deserving to scholars [ulama] not to accept gifts from kings and governors, because the refusal of gifts would make their [ulama] faith more secure, their honor clearer. On the other hand, when they advise [kings]; their advice would be more acceptable. The king and the governor should not become upset or angry with a scholar or a Shylkh who does not accept a gift from him, or from anyone of the army and so forth. No, he [the king] should thank Allah, the Most High, who maintained in his (the King's and Governor's) time this type of person who follows the way of the vererable forefathers. The king or the governor should be careful not to be subjugated to low opinion about that scholar. He [the king] should not think that the scholar did not accept his gift only for the purpose of gaining good reputation, being 
a hypocrite, asking for more, having a low opinion about the king, or insulting his honor. Nay, the king or the governor must have fear of those scholars and shylkhs, who look forward to what is in his hand and in his treasury. The king or the governor should suspect their. councils if they advise him. By Allah! begone with their sincere counsels to the KIng! Because, how could one advise others as long as he cannot advise himself?! How could one be a sincere advisor to the sultan, while he is totally inclined towards worldly things; clearly and by way of suggestion. Nay, the king should leave the people of Allah to what Allah puts in their hearts, which makes them decide to accept or refuse the gift. If they accept the king's gift, then he should leave them alone sincerely. When the hearts of the people of Allah feel happy about the king, then he will be under the care and protection of Allah. As it is said about friends of Allah, in the following holy hadith: "Those are the people (friends of Allah) who never cause troubles for one who sits with them while they are st111 in their temporary bodies." How much greater it is when sitting with them through the eternal secrets [the soul]: May Allah make us blessed by them; in death or in life.

The Sultan Should Be Humble and Kind to His People

The king should always ask Allah for more of His bounty upon him. Hẹ also should ask Allah to make him die as a Muslim; following the example of Joseph, peace and blessing upon him, when he said: "Make me to diẹ submissive (unto Thee) and join me to the righteous," [S. Joseph, A-101, p. 181]. Among the conditions of dying a Muslim are, the strong use of 
wisdom, and justice, and just policies. There are also other conditions such as inspecting the countries' affairs, governors and secretartes. There 1s, also, looking after the affairs of the needy and poor people, following the example of the kings of the earth, such as prophets, saints, and the righteous.

The Prophet David used to disguise himself in order to walk among the children of Israel, asking them what they thought of David's [his] rulership. David disguised himself for fear that there were people who were wronged or could not reach him in time of need and who had not been satiated by the coolness of his justice. David did that because he knew that Allah would ask him about his subjects. He also, was aware of the Most High having said:

0 David Lo! We have set thee as a viceroy in the earth, therefore judge right between mankind, and follow not desire that it beguile thee from the Way of Allah. Lol those who wander from the Way of Allah have an awful doom, for as much as they forgot the Day of Reckoning. [S. Sad, A-26].

0 the KIng, may Allah help you, do you know what the Day of Reckoning is? It is the Day [described] in the Quran as follows;

:- every nursing mother will forget her nursing and every pregnant one will be delivered of her burden, and thou (Muhammad) will see mankind'as drunken, yet they will not' be drunken, but the doom of Allah will be strong. (upon them). [S. Pilgrimage, A-2].

On the day when a man fleeth from his brother, and his mother and his father, and his wife and his children, every man that day will have concern enough to make him heedless (of others). [S. The frowned, AA-34-37].

That day when the crier calls upon the wrongful to be cursed and away with them, but for the just people to be close [to Allah] to get his favor, [as the Most High said]: "And a crier between them crieth the curse of Allah is on evil-doers. Who debar (men) from the path of Allah and would have it crooked:" [S. The Heights, AA-44-45]. 
The previous ayah refers to those who Ignore the Book of Allah, called the path of Allah in the above mentioned ayah, when they judge and rule.

That is why David feared for himself, disguising himself in order to know the truth [about his subjects] personally.. David kept doing that (1nvestigation) until Allah sent an angel to say to him; "What an excellent slave David would have been, if he had been making his living with his own hands." [by saying this] The Truth weaned David from taking anything from his subjects' money. After that David. ate only from what his hands earned from [making doats of ma11]. Similar to what David did, Umar Ibn al-Khattab did too. Umar was the first one to create the patrol by night, which is guarding Muslims' houses,' travelers, and their caravans.

We know about him [Umar], may Allah be pleased with him, that one night he was raving when he saw a woman surrounded by crying children. There was a pot on the fire, that woman had filled it with water, Umar got closer asking the woman; "O the slave girl of Allah, why are these boys crying?" The lady said; "Because of hunger." Umar asked; "How about that boiling pot?" She sald; "I am putting them off with that pot, tricking them, that there is food in until they sleep." When he heard that, he sat down weeping. Then he went to the house of Charlty, where he took a sack full of some flour, clarlfled butter, dates, fat, clothes and dirhams. Then Umar told his man named Aslam; "O Aslam, put the sack on my shoulder." Aslam sald; "0 the commander of the faithful, let me carry it for you. Umar said; "You have no mother;" "I'11 carry it because I am the one who will be questioned about this matter in the Hereafter." 
Umar carried that sack on his shoulder to that woman's house, then he put flour, some dates, and clarified butter in the pot. He started cooking and stirring the food and blowing the fire [with his mouth]. The smoke could be seen coming out through his beard. After he finlshed the cooking he served the food and fed the boys until they became full. Then Umar, may Allah be pleased with him, left.

[Another time] a group of merchants arrived to Madina and they stayed in the Mosque. Umar sald to his ons, Abd a1-Rahman; "Would you guard those merchants?" Abd al-Rahman sald; "Yes." Then Umar and his his son kept guarding the merchants and praying as much as was possible through the night. During that night, they heard a boy cryIng, then Unar went towards the sound of that crying and told the boy's mother to fear Allah by being kind to her child. But after a while, the child began to cry again, and Umar repeated his saying. Then he returned to his place. By the end of the night the boy was crying again, then Umar went to the boy's mother teliling her; "Woe to you! I do not think you are a bad mother! Why do I see your child can not be quiet this 'night?"

She said: "O a slave of Allah! You are annoying me! From tonight on, I am training the boy to get used to being weaned, but he is refusing.".

When Uymar asked why, she said; "Because Umar allocates [allowances] only for children who are weaned."

"How old is he?" Umar asked

"Such and such many months," she answered.

"Wait, don't wean him", Umar said. Then he went to lead the Dawn prayer, hardly seeing people, because of what he had learned. After he 
finished the prayer, tears overcame him, and he said; "How miserable Umar is! How many of the Muslim children has he killed!" Then he ordered a crier to announce [to the people] not to hurry to wean their children because Umar would allocate allowances to every Muslim born. Umar, may Allah be pleased with him, used to go out at night looking after a crippled, blind, old lady, tending her personal needs, [Another time] When Umar returned from his trip from Syria to Median, he withdrew from the people to investigate others. He went by himself to an old lady in her tent. The old lady asked Umar; "0! You! How is Umar doing?"

"He has just come back from Syria," Umar said.

"May Allah not bless him," she said.

"Why?" Umar asked.

The old lady answered; "I swear by Allah, since he has become the Caliph, I recelve neither a dirham nor a dnar."

"How would Umar know about you in this [1solated] place;" Umar said.

The old lady replied:

Praise to Allah! I never thought that one could be in charge of people's affairs without knowing what is between its [boundries] east and west.".

Then Umar wept and said to himself: "Alas for you Umar! Oh! My quarre1s! Everybody is more comprehensive than you Umar!"

Then Umar said to her; "For how much would you sell the wrongs that Umar has done you, because I have compassion for him against Hell."

"Do not scoff me! May Allah have mercy upon you,": the old lady sald.

"I am not scoffing, why should I?". Umar said. 
Umar kept trying unt1l he had bought back the wrong he had done to the lady for twenty five dnars. While Umar was doing that, All Ibn Abi-Talib and Abdulla Ibn Mas'ud, may Allah be pleased with them, arrived and greeted Umar, saying, "Peach be with youl, the Commander of the faithful"

Then the old lady put her hand to her head saying, "How evil I am! I have insulted the Commander of the falthful to his face."

"Do not worry, Allah's mercy is upon you," Umar said." Then he asked for a piece of animal skin on which to write, but he did not find that piece of skin. Then he tore off a piece of his fur to write the following;

This is the wrong that Umar bought from so and so up to the day for twenty five dnars. Whatever she claims against me when I stand before Allah in the Day of Resurrection, I will be cleared of that claim. All and Ibn Mas ud have witnessed this.

Then Umar gave the document to Alf saying, "If I leave before you," In other words, if I die before you do, "then put that document In my coffin."

So, $0 !$ the King, may Allah strengthen you look into this biography and do the same or something closer to that for your subjects, may Allah allow you to die a Muslim and join you with the righteous.

Umar was a just and humble man, and greatly respected by other Kings, who also feared Umar even from. such and such a month's distance. Umar's stick, that he used to discipline people with was feared more by the people than the al-Hajjaj's sword.

Being respected can not be acheived by seclusion, arrogance or greatness, but only fearing Allah, submission to Him, and being humble towards HIm, the Great and the Almighty. So If you [the king] want 
your enemles to fear you and kings to. submit to you, then fear Allah and rule with justice.

Umar used to wear a patched Jubbah [a long outer garment], parts of it made of skin. He used to rome in through the markets, carrying his stick on his shoulder, that which he disctplined people with. When he used to see an unravelled thread, he gave an order for it to be rewoven. He picked dates pits and threw them in people's houses, in order that people should use them, (Once) Umar made a speech to the people, wearing a wrap, that had twelve patches.

The N1le of Egypt obeyed him [when Umar ordered it to reflow]. The earghquake obeyed him and stopped, when he hit the ground with h1s stick, saying to It as If, "I am not Just on your surface, than shake", then it became quiet.

Umar dispatched an army to the son of Khossuau [the King of Pers1a]. He appointed $\mathrm{Sa}$ ad Ibn Abi-Waqqas, as the che1f of that army and Khalid Ibn al-Walld as the leader, when the army reached the Tigris River, they could not find a ship to cross the river. Then Sa' ad and Khalld, stepped toward the river saying to it,

0! The sea! You flow according to Allah's command. So, by the sanctity of Muhammad and the Justice of Umar, the viceroy of Allah, do not come between us and the crossing.

Then they passed through to al-Mada'in [the Persian capltal] with their men, and horses and their camels, without wetting even one hoof.

Unar carried out the command of Allah, upon one of his sons and killed him, as Ibn Abbas reported it.

Umar used to say "If I sleep during the day, than I'11 lose the subfects; [rights] and if I sleep at night, then I'11 be losing my self" 1.e. [not praying]. "So, how could I be sleeping at both these times?" 
If walis [governors] appointed by Umar do not visit 111 people or look after the weak, Umar dismisses them.

Umar appointed his client Hunayy, In charge of charity affairs, and told him: "O Hunayy, be kind to people and protect yourself, against such wronged persons who envoke evil towards you, by their prayers, which would be answered." [By Allah].

The governor of Kufa, Sa ad Ibn Abi Waqqas, wrote Umar, asking his permission to build a house to live in, Umar's reply was: "build what would cover you from the sun, and protect you from the rain." Umar used to ask the people [who came to Medina, frop other states], about their governors, as to how they were conducting the states affairs? Some people from Homs [in Syria], passed by him on one of these occassions, Umar then asked them: "How are you and your governor?" the people's reply was; "0! the commander of the faithful, it is good except, he build a high house to live in." Then Umar sent someone to burn the door of that governox's, and tell hin to come to Medina.

When that governor arrived at Median, Umar said to his men: "keep hIm away from me as a prisonor In the sun for three days." After that, the governor was kept in the sun for three days, Umar took him to volcanic country near Medina, named a1-Harra. Then Umar ordered him to take his clothes off and to wear a wrap. Then Umar handed him a pall, telling hIm: "get water [from the well] for these camels," When the governor finished the work, he was very tired. Then Umar: asked him: "how long has it been since you have done this type of work?" The governor replied: "a long time, commander of the falthful." 
house, making yourself higher than other Muslims, especially widows and orphans; Go back to your job and do not do it again."

I [Alwan] say:

Perlshability, far removed from the mercy of Allah, away with those governors who are not contented with the former kings places. Even more, they created bulldings for drinking wine and practicing sins. Woe to them from the great punishment of Allah in the hereafter.

Our master, Umar [Ibn a1-Khatta] wrote Ab1 Musa al-Ash ar1:

Then after....the happiest ruler is the one whose subjects are happy with him; And the most miserable ruler is the one who makes his subjects miserable. Take care not to deviate, because if you do, then your governors will deviate too. Then you will be like an animal that saw the green grass on the ground, and $1 t$ ate $i t$ in order to become fat, but its death was found in its cloven hoofs.

Thus, look [readers 2 into these revealed preachings. Look inţo them with awakening hearts, and with a human soul that is humble and submissive to Allah. You, people, should know that, what increases in this present 1ife of this world, must also decrease. What is in this life of this world is tempting it will also be comtemplatable, and what goes up it must come down. What is in great quantity must become lessened.

How excellent! are these statements, which were spoken by anonymous persons:

1) When something reaches its peak or climax than it starts receding. So, its reduction should be expected as when it said, this completed.

2) This present life and the one who seeks it are nothing, because its days are only loans.

3) Suppose life has given one, what is needed easily This must also someday, come tolts end, won't it?

4) This life is like a passing shadow.

5) Suppose that you became the king of the world and the people submitted to you. Then what is the end of this? 
Is'nt that the end, that you will die and $11 \mathrm{ve}$, in a deep grave, when people cover you with dust?

[Alwan says]: Therefor, whosoever learns lessons from others experiences, are 1icky persons, but the miserable ones are those who learn from their own follies.

What is coming definetly in [the future] is similar to what happens in the present time, Therefore, the king must sit in his retreat, even if it is a moment, in order to think about the whole matter, its beginning, its end, and its goals. When he has done this, he will realize that this sovereignity has come to $h 1 m$ on $1 \dot{y}$, because of the destruction of the kings in the past. As this happened for hIm, the sovereignity also. will come upon those after him, only after this destruction and death. As the most High Allah Almighty said in the Quran, to the most honorable of his creatures, the Prophet:

We appointed immortality for no mortal before thee. What if thou diest? Can they be immortal?. Every soul must taste of death, and we try you with evil and with good for ordeal. And unto us ye w111 be returned. [S. The prophets, AA-34-35].

Allah the Most High, also sald to his Prophet, Muhammad: "Lo! Thou wilt die, and 10 ! they will die. Then $10 !$ on the day of judgement, before your lord ye w1ll dispute." [S. The Troops, AA-30-31].

If death is a rest for us, then it would be a comfort for every living soul, but when we die, then we'11 be rewarded and Allah will reckon with us about everything. Thus, I wish I knew how the condition of a slave [of Allah] would be when a great angel [Azrael] comes to him! Azrael has a great majesty and he also is very fearful Man would die just because of the terrifying appearance of that angel, if Allah did not make that person firm [to take death].

We have been told that when one of the carriers of Allah's Throne, 
[angels] sees the death angel, he becomes so thin as one strand of hair, because the angel Azrael's majesty and terror, thats given to him by Allah. Azrael holds the world in his hands, the same as when on of us holds a platter or an egg in his hands. In addition to that, Azrael has honourable alds, blessings and peace upon them. Those alds, hasten to a dying person, then one of them holds his right hand, another holds the left one, another holds the right foot, and another holds the left one. Without those aids, no place could include the death angel, neither a house nor a desert.

It is enough to know how terrifying he is, [Azrael] when we 11sten to the Prophet's saying: "One of the death agonies, is harder than piercing with a sword,"100" It is said that death agonles are more painful than scissoring and sawing [In human flesh]. If one hair of pain of a dying person was put upon the dwellers of heavens, and earth, then they would die of 1ts pain. It is said that after Allah made Moses die, the epitaph of Moses, blessing and peace upon him, upon our Prophet, and all prophets, He asked Moses how did he find the death pain. Moses rep1led: "It is 1ike stripping off a live'sheeps skin." In another saying that Moses had sald:. "It Is like frying a living sparrow, that cannot die to rest and connot fly to be safe." Then Moses was told that his pain was reduced. This was the case of Moses who spoke with Allah, (the eptitaph of Moses).

Simflar to this story, is the story which has been told, about the beloved by Allah, Ibraham. As for the beloved, the honourable, the noble Muhammad, blessings and peace upon him, while he was dying, pain came over him, then he took a can full of water to cool himself off. He also covered his face with a cloak, saying: "There is no god but 
Allah. Verily death has agonies". 101 In another speech of the Prophet, he sald: "0! Allah help me to take the death agonles". That was the case of the chosen perfected. But how about us? There is no strength nor power, but by the means of Allah, the Most High, who sald:

The1r reconing draweth nigh for mankind, while they turn away heedless Never cometh there unto them anew, reminder from their lord, but they listen to it while they play, with hearts preoccupled... [S. Prophets, AA-1-3]

Let us suppose you have lived as long as Noah did. Then you become weaker and weaker, then you die, so living a long time is not worthy since you must die eventually.

We have known that Mu'awiya Ibn Ab1 Sufyan, the commander of the faithful in Syria, while dying gathered his famfly, then asked them: "You are my family aren't you?" the reply was: "Yes we are, may Allah make us your ransom.", they sald. Then he sald: "I fought, worked hard and earned wealth for all of you?" they replied: "Yes, may Allah make us your ransom." He said: "This, my life 18 leaving my foot, return It, if you can." They wept and said: "We have no way to do that." Then Mu'awlya raised hils volce crying, and said: "Who is going to be decelved after me by this present life of this world!?"

$\mathrm{Mu}^{`}$ awlya was sorry when sorrow does not help. Then Mu'awiya, may Allah be pleased with hIm, sald:

Supply yourself with good works, by doing goodness; Because what man did will be his amusement in his grave. Man is only his family guest, he stays with them for a short time, then leaves.

Sulatman Ibn Abd a1-Malik, who was an Umayyad caliph, one day, It was a Friday, he looked at himself in the mirror, he was wearing the best of his clothes and of his perfume. He was tall, fair, handsome, eloquent, and knowledgeable. He admired himself and said: "I 
am the young king", he asked his slave girl in the courtyard, what she thought of him, she replied saying:

How excellent an object of delight you are, if you will. Iive forever. But there is no Immortality for man. We do not see anything wrong with you that people can critfie, but you will pass away.

Alwan says: How brave and knowledgeable she is! Then Sulaiman turned around and left for the Mosque: He went up to the pulpit to make the Friday speech. He began in a loud voice that could be heard from the end of the mosque. Then a fever came over him, which made his voice lower and softer, so much so that people all around him could not hear him. After he finished praying he came back, leaning on two people and dragging his feet.

Once a man came to Sulaiman and satd: "0! the commander of the faithful, by Allah and the crying. As for Allah, we know Him, but what is crying?" Sulaiman sald. The man said that it is His, the Most High's saying: "And a crler in between them crieth. The curse of Allah is on evil doers." [S. The Hights, A-44].

Sulaiman asked the man: What wrong is done to you?. The man then answered saylng: "Your governor has taken my country estate by force." Then Sulaiman stepped down of $f$ of his throne, and removed the carpet, putting his cheek on the floor, then he said: "By Allah I won't take may cheek off the floor unitl a document is written, for this man to get his rights back". The document was written while Sulaiman, had his. cheek on the floor. What made Sulaiman do that is his fear of Allah's speech, which breaks his heart and weakens his inards. How many! How many!, before and after and so forth, until there is nothing remaining but the blessed face of your Lord.

Once there was aking, who built a wonderful palace; it was 
designed in a way, so excellent in manner of exquisite beauty. Foun-. tains of water were designed, in unbelievable dimensions of construction, which made water flow in clrcles and then join each other at the center. It was not a long time before the king and his supporters died. A. walker in that palace saw the following inscription written on the palace wall:

These are places of folks, whom I know lived in comfort, and living safely. The disasters of time cried upon them. Then they turned towards the graves. Now they are destroyed completely.

Therefore, the king should think about such matters like that, whIch perhaps make him soft hearted, and to prepare himself for deaths journey, that he must eventualiy take. As the master of mankind, the Prophet Muhammed said: "The wise is he who examines his conscious, and works for what comes after death....etc." 102

The Prophet was asked: "What Is the wisest person? Then he said: Who is he, who remembers death most and the best, in preparing himself for $1 t^{\prime \prime}$.

Why should not he [the king] be ready for the great terror death, when the members in the body, say goodbye to each other because they won't see each other again, unt1l the day of judgement. The king will look with his own eyes at his army, soldiers, slaves and his servants, but no one of them can help him or protect him against death. Then he [the king] w111 be sure that he is leaving them, for a dark black grave. Nothing from his treasures will go with him when he dies except a plece of cotton and another fabric. If he prepares for his grave, with good works and dutiful justice, and spread kindness, [in his grave] will find a blessedness. Otherwise, there is no strength, nor power but by the 
means of Allah, the Great, the Most High. The sultan will be there in the grave alone by himself, and cannot contact his family or his children. Instead of the high palaces. He will be in the bottom of a deep grave, jalled until the day of judgement, when he comes out on that Day, he w111 se a multitude of changes, such as the earth in turmoll, the angels, moving h111s and valleys, rising seas, folding and fading of the sun and Its light, open pages and other frightening things. On that Day he [the sultan] will be confused in thought, frightened, in need of a shelter, barefoot, naked, sad, alone and a stranger. Also on that Day, his soldiers and followers will flee from him. The sultan's protection and defense will disappear, and he w111 be surrounded by honourable angels, who never disobey Allah's command, and they do what they are told to do. He [the sultan] will stand in the ground where people w111 be brought together, as the following ayah describes: "When right confounded. And moon is eclipsed. And sun and moon are united. On that day man will cry, wither to flee. Alas! No refuge! Unto thy Lord is the recourse that day." [S. The rising of the dead, $\mathrm{AA}-7-12]$.

On that Day, the Greatest King [A1lah] w11l say: "Where are the kings of the earth. Where are the tyrants and the Khosorus?" Who has the power of sovereignty? Allah the One and The Only Most Powerfull.

The sultan will be in a burning sun, that is close to heads as far as the whites of the eyes. There won't be a shaded place or shade to protect from the sun, but justice and 1ts 11keness, as the Prophet sald: "Allah will shade seven people on the Day, where there is no shade but His shade! These people are a just Iman....etc." 102 
al-Abban1, Mahmud. S1lollot al-Ahadith al-Da!1fah, second edition, The Islamic office, Damascus, 1964.

a1-Ajlun1, M. Kashf al-Khafa wa Muz11 al-1bbas, Dar Sad1r, Be1rut, 1921.

'Afif1, A. al-Tasawuf, firet edition, Dar al-Ma'rif, Ca1ro, 1963.

a1-fasi, A. Sharh Hizb al-Barr, first edition. The Asharl Library, Calro, 1969.

a1-Ghazzl, Najm a1-D1n. a1-Kawak1b a1-Salrah. Edțted by J. Jabbur, American UnIversity of Befrut, 1945.

a1-Juyush, M. Bain a1-Tasawuf wa al-Adab. The Anglo-Egyptian Inc., Calro, (no date).

al-KInant, M. Tanz1h a1-Sharla al-Marfu'a. The Calro Library, Cairo, 1958.

Alwan, A. al-Madad al-fald (ms.)

Alwan, A. Important Counsels to KIngs and Imams (ms.)

a1-Munufi, M. al-Madkha1 ila a1-Tusawuf a1-Islami. The National Inc., Cairo, (no date).

a1-Nabhant, Yosef. Jam1' Karamat a1-Awlya. Edited by Ibrahim Awwad, first edition, al-Bab1 al-Halab1 Sons Inc.. Ca1ro, 1962.

al-Raqld, Mahnud. al-Ghazu al-Uthman1 11 Misr. Shab al-Jamia Inc., Alexendria, 1968 .

'Ayyad, Ahmad. al-Tasawuf al-Islami. The Anglo-Egytian Inc., Cairo, 1970.

a1-Zirik11, K. al-Alam. Mustafa Costasomas Inc, 2nd edition, Cairo, 1959.

Brockelmann, Carl. History of Islamic Peoples, Capricorn, New York, 1960, Revised 1973.

The Encyclopedia of Islam. New edition, Luzac \& Co., London, 1960.

Harris, W. \& J. J. Levey. The New Columbla Encyclapedia. Columbla University Press, New York, 1975.

Ibn Taymiyah, A. al-Muntakhab min Ahadith al-Ahkam. The Traditional Library, Calro, 1966. 
Ibn Tulun, M. Mufakat a1-Khfllan. Edfted by M. Mustafa, The Public Egyptian Inc., Ca1ro, 1962.

Khalifa, Haj1. Kashf a1-Zunun. Wikalat a1-Maar1f a1-Umumiyyah, Istanbul, 1941.

Mahmud, A. al-Madrasah al-Shadh1liyyah al-Had1thah. The Modern Books Inc., Calro, 1967.

Pickthall, M. The Meaning of the Glorlous Koran. New American LIbrary, New York, 1969.

Vat1klotus, P. J. The Modern History of Egypt. Fredrick A. Paeger Inc. New York, 1969 . 
FOOTNOTES

(1) The New Columbia Encycloped1a, p. 2031.

(2) Brockelmann, p. 318 .

(3) Ibid, p. 318-321.

(4) IbId, p. 234-236.

(5) Vatikiot1s, P. J., p, 21.

(6) Brockelmann, p. 234-236.

(7) al-Raq1d, p. 112-128.

(8) ${ }^{2}$. Brockelmann, p. 288-289.

(9) Encyclopedia of Islam, V. 3, p. 510.

(10) al-Gazz1, V. 2, p. 212.

(11) Ibid, V. 1, p. 47

(12) Ib1d, V. 2, P. 213, 224.

(13) al-zirik11, Kh., Al-'Alam, v. 4, p. 377.

(14) Encyclopedia of Islam, V. 1, p. 388.

(15) 'Alwan, Important Counse1s (ms.) follo 17A.

(16) Encyclopedia of Islam, V. 1, p. 226.

(17). 'Alwan, Important Counsels (ms.) fallo 17B.

(18) 'Alwan, al-Madad al-fa'ld (ms.), p. 181.

(19) Al-Gazzi, V. 1, p. 272, 273.

(20) Ibid, V. 1, p. 210.

(21) al-Munuf 1, M., p. 25, 40 .

(22)' 'Af1f1, A., al-Tasawuf, p. 92.

(23) al-Juyushi, M., p. 14, 38, 45.

(24) 'Ayyad, Ahmad, p. 139.

(25) 'Alwan, al-Madad al-fa'id (ms.), p. 109. 
(26) Ib1d, p. 204.

(27) a1-Gazz1, V. 2, p. 206.

(28) al-fast, Sharh Hizb Al-Barr, p. 31-33.

(29) al-zirikl1, al-'Alam, V. 5, p. 83.

(30) Mahmud, Abd a1-Halim, 81-Madrasa a1-Shadhilyye a1-Had1tha, p. 91 .

(31) al-fasi, p. 34 .

(32) Mahmud, Abd al-Halfm, p. 71.

(33) Alwan, al-Madad al-fa'1d, p. 36-37.

(34)" Al-Ghazz1, V. 1, p. 242-243.

(35) Ibld, V. 1, p. 59-68.

(36) Ibn Tulun, M., V. 1, p. 328-329.

(37) Ibld, V. 2, p. 107, The ayah "...And Allah averted..." 1s from the Surah of Clans, Ayah 25.

(38) 'Alwan, a1-Madad a1-fa1d, p. 201-202.

(39) Ib1d, p. 208, the ayah 'Alwan quoted 18 from the Surah of Cattle, ayah 9.

(40) Ib1d, p. 215-216.

(41) IbId, p. 230.

(42) a1-Gazz1, v. 2, p. 201-202.

(43) IbId, V. 2, p. 50-52.

(44) a1-Nabhani, Karamat al-Walya, v. 2, p. 370. The ayah 'Alwan quoted is from the Surah of

(45) al-Ghazzi, v. 2, p. 201-202.

(46) Ibtd, p. 50-51.

(47) al-Nabhan1, v. 2, p. 50, 122.

(48) al-Ghazzi, V. 2, p. 229-232.

(49) al-Zirikl1, Kh., al-'Alam, v, 5, p. 129.

(50) Khalifa, Haji, V. 1, p. 1142-1145. 
(51) a1-21rik11, v. 5, p. 129.

(52) Alwan, Iinportant Counsels, follo 1 .

(53) Ibld, follo 1 .

(54) IbId, follo 1 .

(55) Ibld, follo 8-9.

(56) Ib1d, follo 48 .

(57) Ib1d, follo 38-39.

(58) Ib1d, follo 30.

(59) al-'Afliuni, V. 2, p. 362, this had1th was reported only by one scholar of Hadith, named al-Daylami.

(60) Ibid, V. 2, p. 115, a sound hadith.

(61) IbId, V. 1, P. 447, a sound hadith.

(62) IbId, V. 1, p. 39, a sound hadith.

(63) Ibid, V. 22, p. 250.

(64) al-Muntakhab min a1-Sunna, V. 2, p. 81, a sound hadtth.

(65) a1-qurtub1, V. 12, p. 6, The Prophet sald "everyone of you 1s created in the uterus of his mother of a sperm-drop, then of a blood-clot, then of a lump of flesh, formed and unformed.

(66) al-'Ajlun1, V. 1, p. 440, a good had1th.

(67) al-Kinani, V. 2, p. 225, some of ulama consider this hadith a weak one and some of them said it is a fabricated one.

(68) Mus 11m, The Sahih of Mus 11m, V. 5, p. 71 ,

(69) al-'Ajlun1, V. 1, p. 83, a sound had1th.

(70) Ibld, V. 1, p. 447, a sound hadith.

(71) Ib1d, V. 2, p. 367, reported by the s1x ulama of Had1th.

(72) al-Muntaga, p. 669-670.

(73) a1-Nawaw1, p. 26.

(74) al-'Ajluni, V. 2, p. 225, a sound hadith. 
(75) al-'Ajlunl, V. 1, p. 382, a traceable hadith.

(76) Ibid, V. 1, p. 84, reported only by two Hadith scholars, alBayhaq1 and al-HakIm.

(77) al-'Ajlun1, V. 2, p. 125, a sound hadith.

(78) Ibld, V. 2, p. 370, this hadith was reported only by one scholar, a1-Daylam1.

(79) Ibid, V. 1, P. 209, generally it is a good hadith.

(80) Ib1d, V. 2, p. 209, a sound hadith.

(81) al-'Ajluni, v. 2, p. 224, a sound hadith.

, Ibid, V. 1, p. 39, a traceable had1th.

(82) Ib1d, V. 2, p: 332, a sound hadith.

(83) al-Albani, V. 1, p. 78, a fabricated hadith.

(84) al-'Ajlun1, V. 2, p. 144, reported by Ahmad, Abu Daud and Ibn Majah.

(85) al-Ajlun1, V. 2, p. 305, a sound hadith.

(86) al-'Ajluni, V. 2, p. 399, a sound hadith.

(87) Alwan interpreted "furqan" as victory.

(88) al-Muntakhab min al-Sunna, v. 1, p. 360, a sound had1th.

(89) al-'Aflun1, V. 1, p. 325, reported only by al-Tirmidhi through Abu Hurayrah.

(90) al-'Ajlunt, V. 1, p. 153; a traceable had1th.

(91) Ibn Taymiyah, p. 652-653, a sound had1th.

(92) a1-'Ajlun1, V. 2, p. 2, traceable hadiths.

(93) a1-'Ajluni, V. 1, p. 194-195, a sound had1th.

(94) Ibid, V. 1, p. 53, incompletely transmitted hadith.

(95) Ib1d, V. 2, p. 124, a sound hadith.

(96) Ibid, V. 1, p. 52, reported only by a1-Tabaran1, traceable.

(97) Ib1d, V. 1, P. 129, a sound hadith.

(98) al-Albanl, V. 5, p. 34, a fabrlcated hadith. 
(99) al-'Afluni, V. 1, p. 143, reported by al-Bayhaqi in a weak chain of authorities [Isnad].

(100) al-Kinant, V. 2, p. 365, this hadith 18 not a sound hadith.

(101) al-'Ajlunt, V. 2, p. 347, a sound hadith.

(102) Ibld, V. 2, p. 136, a good traceable had1th.

(103) Ibld, V. 1, p. 447, a sound hadith.

(104) Ibn Taymlyah, V. 2, p. 34-36, a sound had1th.

(105) al-'Ajlun1, V. 2, p. 303, a sound had1th.

(106) The verse number, 16, was taken from The Zahiriyyah Library copy. 